\title{
Multilevel Effects of Student Qualifications and In-Classroom Variables on Science Achievement*
}

\author{
Sıdıka AKYÜZ ARU **
}

\author{
Mustafa KALE ***
}

\begin{abstract}
This research aims to determine the effects of student qualifications and some in-classroom variables related to the school teaching process on the TIMSS science achievement of 4th-grade students in Turkey. It was also aimed to determine the variables that contributed the most to explaining the achievement differences between schools at the student and classroom levels in this study, which was conducted with a causal comparison pattern. The sample of the study consists of 6378 students and classroom teachers of these students. The data of this group was analyzed using the Two-Level Hierarchical Linear Model (HLM). The effects of absenteeism, not having breakfast, use of technology in school, use of technology outside school and home on science achievement scores were found to be statistically significant as a result of HLM analysis. Teachers' perceptions of the inadequacy of the school's facilities and resources, giving feedback on homework, discussing homework in the classroom, and explaining the answers given by the students in the classroom have significant effects on science achievement at the classroom level. These results are related to students in improving the academic performance of primary school students and reveal the importance of a number of psychological and physical characteristics that may affect the teaching process positively or negatively.
\end{abstract}

Key Words: in-classroom variables, student qualifications, science achievement, TIMSS, HLM.

\section{INTRODUCTION}

Keeping the school alive for its purposes in the 21st century, ensuring the happiness and satisfaction of the parties stand before us as an equation with many variables that seems very difficult to achieve (Özdemir, 2013). Therefore, there is a need to re-address education systems at a level that can meet these functions. Accordingly, all the elements that make up the education system are subjected to the evaluation process in order to describe the current situation, to reveal deficiencies and needs, and to determine the activities to be carried out in the future (Bilican-Demir, 2014).

At this point, the information to be provided by the evaluation activity to be carried out is important. Reddy (2005) states that the most efficient way to evaluate countries' education systems is to evaluate the outcomes, which is one of the elements of the system, and emphasizes that the most realistic approach to this issue is international comparisons.

Turkey has been participating in the International Mathematics and Science Study (TIMSS), which is one of the international large-scale test applications since 1999 in this context. TIMSS provides the opportunity to make the necessary changes in light of the scientific data obtained by comparing the Turkish education system with the other education systems at the international level. In addition, TIMSS provides an opportunity to classify the students participating in the application according to their competence levels in line with their achievement scores, to determine their abilities, and to evaluate them.

\footnotetext{
* This research was produced from the doctoral dissertation study titled "Investigation of Variables Affecting Science and Mathematics Achievement of 4th Grade Students: Multilevel Analysis of TIMSS Data".

** PhD., Ministry of Education, Ankara-Turkey, SIDIKAARU@ gmail.com, ORCID ID: 0000-0002-5991-2288

*** Assoc. Prof., Gazi University, Faculty of Education, Ankara-Turkey, mkale@ gazi.edu.tr, ORCID ID: 0000-0002-37271475
}

To cite this article:

Akyüz-Aru, S., \& Kale, M. (2021). Multilevel effects of student qualifications and in-classroom variables on science achievement. Journal of Measurement and Evaluation in Education and Psychology, 12(2), 71-96. doi: 10.21031/epod.756083 
It is seen that the percentage of students who remain below the low level in the field of science (18\%) is approximately 3.5 times the median value of TIMSS when the proficiency levels of Turkish students are examined in the result reports (1999-2015) (Karip, 2017). This result shows that 225 thousand 4th grade students pass from primary school to secondary school with a performance below the low level in the field of science, that is, without basic skills (Karip, 2017). The fact that almost half of Turkish students $(n=3250)$ are at low and lower levels of competence shows that they have difficulties in implementing the basic information they have learned, adapting this information to the problems they encounter, and even remembering (Yücel \& Karadağ, 2016), in other words. Such problems directly affect academic achievement (Mullis, Martin, Gonzalez, \& Kennedy, 2003). The results of the studies conducted on TIMSS data in different years (Büyüköztürk, Çakan, Tan, \& Atar, 2014; Martin et al., 2000; Olson, Martin, \& Mullis, 2008; Özden, 2007; Uzun, Bütüner, \& Yiğit, 2010) show that the science achievement of Turkish students is lower than the mean of overall achievement.

\section{Effects of Student Qualifications and In-Classroom Variables on Achievement}

Meta-analysis studies examining the relationships between student qualifications and achievement (Hattie, 2009; Marzano, 2003) show that factors directly related to the student have a high effect on academic achievement. It was found that the majority of the variance in student achievement was explained by features at the student level in a study by Mohammadpour, Shekarchizadeh, and Kalantarrashidi (2015) examining the characteristics of students, schools, and countries affecting the TIMSS 2007 science scores of 8th-grade students from 29 countries.

It is seen that many student qualities are discussed in the literature. Kaya (2008) discussed TIMSS 2003, with the variables of gender, self-confidence, and home resources at the student level in relation to student achievements. Aydin (2015) defined student-level data as student affective characteristics and student characteristics. İpekçioğlu-Önal (2015) identified student-level factors as gender, educational resources used at home, family participation, homework, and bullying. Sar1, Arikan, and Yildızlı (2017) examined affective characteristics (self-efficacy, attitude, and learning value), resources at home, belonging to the school, bullying, and teaching activities at the student level.

However, it is stated in different studies that student characteristics such as absenteeism, nutrition, and technology use are not adequately examined in research even though the power to explain the variability in achievement is high (Asigbee, Whitney, \& Peterson, 2018; Garcia \& Weiss, 2018; İsmail \& Awang, 2008; Khalid, 2017; Kolasa, Díaz, \& Duffrin, 2018; Liouaeddine, Bijou, \&, Naji, 2017).

Klem and Connell (2004) and Ackerman (2013) emphasized that absenteeism, students' participation in school activities, and regular attendance are factors that directly and positively affect students' motivation; students who continuously participate in school processes develop positive attitudes towards lessons and their homework performance increases. In addition, it is another factor emphasized in studies where students who are oppressed under challenging school conditions, adverse climate, and heavy education programs tend not to go to school and even to leave school (Akey, 2006; Doğan, 2014). Likewise, another factor that closely affects students' academic achievement is nutrition. The Organisation for Economic Co-operation and Development (OECD) reports show that many students struggle with hunger and insomnia to pay attention to the lesson even in the most developed countries (OECD, 2015). Clinton (2013) found that children who are advantageous in nutrition and physical activity are more open to effective learning compared to those who are disadvantaged in this regard. However, Clinton, Rensford, and Willing (2007) state that there is no direct research result in the literature that nutrition increases academic achievement to very high levels. Therefore, nutrition is only one of the factors that are thought to affect achievement.

Another factor ignored at the student level in the studies is students' use of technology. It is known that especially children begin to spend most of their time interacting with new digital media, such as e-books, tablets, and smartphones, with the development of technology (Lieberman, Bates, \& So, 2009). The way that most children who spend part of their daily lives in school are affected by technology may be reflected positively or negatively on their academic achievement. This issue is worth investigating even though parents think that these can be effective and complementary in the 
education of early age children if educational applications that can be used, for example, on phones and other digital media tools, are used in the right direction (Chiong \& Shuler; as cited in Hooper, Mullis, \& Martin, 2013). Therefore, nutrition, absenteeism, and technology use at the student level of the current study were included in order to eliminate the deficiency in the literature and to see its effects on explaining the variance in student achievements.

Hox (1995) states that the qualities of the students, which are the basis of the measurement in the field of education, are affected by the characteristics of the school and classroom in which the student is studying. It is inevitable that useful learning is affected by teaching activities that are among the classroom environment and in-classroom variables since most of the teaching and learning activities take place in the classroom (Hooper et al., 2013; Nilsen, Gustafsson, \& Blömöke, 2016). Hattie (2009) states in the meta-analysis study that in-classroom variables (in-classroom instructional interactions, school resources in classroom materials and lessons, in-classroom evaluation methods, etc.) significantly affect student achievement but that not enough work is done at the classroom level.

It is seen that there are studies on lesson tools, student, and parent characteristics (Aydın, 2015; Çavdar, 2015; Erşan, 2016; Korkmaz, 2012) and teaching method techniques and learning environments used in and outside the classroom, national teacher training policies and teacher education, teachers' experience, teacher qualifications, attitudes towards teacher training, the structure of school management, and leadership understanding when the studies conducted on this subject in Turkey are examined (Aktaş, 2011; Atar, 2014; Sezer, 2016). In addition, there are also studies examining the effect of different teaching methods and techniques related to student achievement at the 4th grade level of primary school (Ayvaz, 2010; Güngör, 2014; Kılıç-Özün, 2010; Selçuk, 2015), in which the results of TIMSS are comparatively examined between countries (Akkuş, 2014), the relationship between international exams and educational policies and equal opportunities in education is examined (Çelebi, Güner, Taşç1-Kaya, \& Korumaz, 2014).

One of the critical factors in the quality of education that directly affects achievement is the comprehensiveness and quality of the resources available at school and for the lessons (Lee \& Barro, 2001; Lee \& Zuze, 2011). The results of TIMSS studies conducted to date show that the students of the teachers who do not have resource shortage in the lessons are generally more successful (Hooper et al., 2013). The concept of in-classroom variables was used by Blömeke, Olsen and Suhl (2016) in their study on the relationship between teacher quality and teaching quality with student achievement. Teachers' qualifications, knowledge-skilling levels, and perceptions are important factors in increasing student achievement. Discussions in classroom processes, explanations of the answers given, and homework are elements that should be planned in advance. The subject of homework is an important factor researched by many researchers to observe its impact on achievement. Trautwein (2007) explains the existence of studies on the frequency of homework and the time spent on homework and states that there is a need for studies on the effect of the effective use of homework in classroom processes on academic achievement.

Many of the studies investigating the relationships of student achievements with determinants at different levels such as students, schools, classrooms, and teachers in the literature (Acar, 2013; Aktaş, 2011; Akyüz, 2006; Atar, 2014; Ekinci-Vural, 2012; Fullarton, Lokan, Lamb, \& Ainley, 2003; İpekcioglu-Önal, 2015; Mohammadpour \& Abdul Ghafar, 2014; Sezer, 2016; Stemler, 2001; Taştekinoğlu, 2014; Yaman, 2004) ignore the effect of classroom-level characteristics on achievement.

In addition, it is seen that achievement is examined only in the context of student-derived factors (Kunuk, 2015), student-derived and teacher-derived factors (Akyüz, 2006; İpekcioglu-Önal, 2015; Kaya, 2008), and teacher-derived factors (Aktaş, 2011; Atar, 2014; Sezer, 2016; Yaman, 2004), only school-derived factors (Stemler, 2001) or school and student-derived factors (Acar, 2013; Aydin, 2015; Fullarton et al., 2003; Lamb \& Fullarton, 2002; van den Broeck, Opdenakker, \& van Damme, 2005; Yatağan, 2014) when the studies conducted at home and abroad and examining student, teacher, and school characteristics on the results of large-scale tests such as TIMSS (Akkuş, 2014; Aktaş, 2011; Akyüz, 2006; Atar, 2014; Aydın, 2015; Çavdar, 2015; Erşan, 2016; İpekcioglu-Önal, 2015; Kaya, 2008; Korkmaz, 2012; Sevgi, 2009; Stemler, 2001; Yatağan, 2014;) are examined. The relationships 
of achievement only with the interaction of variables at student and school levels were investigated in some studies conducted abroad (Blömeke, Suhl, \& Kaiser, 2011; Hooper et al., 2013; Kyriakides, 2006; Martin, Mullis, Foy et al., 2016; OECD, 2013).

However, it is necessary to investigate in-depth and in relation to each other all the variables that may affect achievement and take place at different levels in future studies. The fact that achievement is a goal reached at the end of the processes where mental activities are effective is proof of this necessity (Nilsen et al., 2016). The versatile structure of the mind suggests that achievement is too complex a concept to be measured only by standard tests, and therefore needs to be investigated in depth by examining in different contexts. For example, Creemers and Kyriakides (2006) state that this stratified sampling structure of large-scale tests, in which students are clustered within classrooms, classrooms within schools and schools within countries, may change in relation to student, classroom, and school characteristics and will be affected by the conditions contained in these contexts. It is therefore important to conduct multi-faceted research in which achievement is assessed in the circumstances in which these conditions arise.

It is understood that there is a gap in this regard considering that nutrition, absenteeism, and technology use from student qualifications and sources, classroom discussions, and homework from in-classroom variables are not handled together in the studies conducted in Turkey (Akkuş, 2014; Aktaş, 2011; Atar, 2014; Aydın, 2015; Ayvaz, 2010; Çavdar, 2015; Çelebi et al., 2014; Erşan, 2016; Güngör, 2014; KılıçÖzün, 2010; Korkmaz, 2012; Selçuk, 2015; Sezer, 2016). Therefore, this study focuses on the effect of these variables selected at student and classroom levels together on students' science achievement.

\section{Objective of Research}

This research aims to estimate the extent to which these variables affect the TIMSS science achievement of 4th-grade students by combining different variables at student and classroom levels with the help of the Hierarchical Linear Model. In addition, the study also aims to determine the student qualifications and in-classroom variables that most explain the inter-school achievement variables. Answers to the following questions were sought for these purposes.

Research questions:

1. Are there significant differences between the classrooms in terms of students' science achievement?

2. Do the science achievement scores of the students differ according to the in-classroom variables discussed at the grade level? What are the classroom level variables that explain this difference if there is a difference? How much of the variance in science achievement scores are explained by variables with significant effects?

3. Do the science achievement scores of the students differ according to the student qualifications discussed at the student level? What are the student-level variables that explain this difference if there is a difference? How much of the variance in science achievement scores are explained by student-level variables with significant effects?

\section{METHOD}

A causal comparison pattern, one of the quantitative research methods, is used since the study aims to determine and compare the variables affecting the science achievement measured in TIMSS 2015 among the various student and classroom characteristics of the 4th-grade students discussed within the scope of TIMSS 2015 application in this study. Causal comparison studies aim to determine the causes of a situation or differences between groups, what is effective in the formation of this situation, in other words, the causal variables affecting the variable related to the result or the results of the effect without any intervention on the participants and conditions (Büyüköztürk, Kılıç-Çakmak, Akgün, Karadeniz, \& Demirel, 2011; Fraenkel, Wallen, \& Hyun, 2012). 


\section{Sample}

A total of 6456 4th grade students from 242 schools and classroom teachers of students from Turkey $(n=249)$ participated in TIMSS 2015 application (LaRoche \& Foy, 2016). A two-stage stratified sampling method was used in TIMSS 2015 sample selection. Schools in the first stage and random classrooms in the second stage were selected from these schools.

This study was carried out with data on all 4th-grade students participating in TIMSS 2015 and classroom teachers of these students $(n=249)$. However, it was observed that there were deficiencies in the data obtained from the sample in the data file. Therefore, Missing Value Analysis was performed for missing values in order to finalize the sampling.

It was found as a result of this analysis that Little's MCAR test was significant $(<.05)$ and the existing lost data in the data file showed a systematic distribution. The listwise deletion method can be applied if the lost data is below 5\% in such cases (Garson, 2008). Accordingly, the loss rate in each variable was examined for each student in the data set, and the listwise deletion method was not preferred because it was more than $5 \%$.

One of the alternatives to addressing loss values that are over 5\% and distributed systematically is to make predictions of lost values/assign an approximate value, also known as imputation. "This process can only be performed for quantitative data" (Çokluk, Şekercioğlu, \& Büyüköztürk, 2018, p. 11). The three most common methods of performing these operations are using historical information, assigning mean values, and regression (Çokluk et al., 2018; Mertler \& Vannatta, 2005; Tabachnick \& Fidell, 2001). "Assigning mean value in these cases is the best prediction method if the researcher has not been working on research for a long time and has no other information" (Çokluk et al., 2018, p. 11). Therefore, this method was preferred, the mean was calculated by using the obtained data, and these means were assigned to the variables containing lost values.

In the last case, 6348 students and 241 classroom teachers constituted the sample of the present study. In addition, the weighting values of the students and teachers in the TIMSS 2015 data file were used in order to ensure an equal representation of all students and teachers in the selected sample in the study.

\section{Data Collection Tools}

\section{Science achievement test}

The science achievement test consists of items half scored as multiple choice and the other half scored as multi-category. Multiple-choice items have four options and one correct answer. The correct answer for each multiple-choice item is 1 point. Incorrect answers do not affect the correct answers. Students create their own answers in the items scored as multi-category. Students make explanations, verbally or numerically support their answers, draw shapes, or use data in this type of question. Items scored as multi-category are evaluated with scoring guidelines developed for each item (Martin, Mullis, \& Foy, 2013). These scoring guidelines contain the basic characteristics of an appropriate and complete answer for each item. The guidelines focus on the evidence of the type of behavior that the item assesses. Student responses that are partially or completely correct are clearly defined in the manual and scored as 0-1-2 or 3. In addition, the possible different student responses in the guide also direct the experts. Only the skills required by the evaluated subject are focused on, not the writing skills of the students, while scoring items scored as multi-category (Martin et al., 2013).

Items are distributed into learning areas as $45 \%$ life sciences, $35 \%$ physical sciences, and $20 \%$ earth sciences. In addition, the items show cognitive field distribution as $40 \%$ knowing, $40 \%$ as applying, and 20\% as reasoning (Martin et al., 2013). 
Plausible values: The science questions in TIMSS consist of 14 different test booklets. An item pattern has been developed so that a common question can be found in both test booklets. Therefore, it is not possible to test each student on the same items. The science achievement score of each student is predicted as if the student answered all items. It is the range or distribution of possible values predicted for the competence of each student rather than each observed score at this point. Five possible values (plausible value, PVSCI1-5) were reported for each student's science achievement score in the TIMSS data file (Martin, Mullis, Hooper et al., 2016). These possible values obtained as a result of the science achievement test application were used as indicators of TIMSS science achievement, which is the result variable of the current research. The HLM program simultaneously incorporates these five possible values into the analysis by assigning multiple data and assigns a mean value. Therefore, analyses were performed by averaging the possible values in the PV1SCI-PV5SCI range in relation to each student's science test within the scope of the research.

\section{Teacher questionnaire}

All variables in the classroom level of the research were obtained by teacher questionnaire. Ten out of 21 items in this questionnaire were related to science and were filled in by the classroom teacher. The items in the teacher questionnaire data file were determined as the variables Perception of the importance of school in academic achievement, perception of safe and regular school structure, problems related to school facilities and resources, difficulties encountered, teaching limited to student needs, giving feedback to students' science homework, discussing science homework in the classroom, checking science homework, the importance given to research, lesson-day life connection, explaining the answers in the classroom, using interesting materials, completing challenging activities, classroom discussions, new content-present content connection, deciding on problem-solving periods, and explaining their thoughts in line with the relevant literature.

\section{Student questionnaire}

The variables at the student level were obtained by student questionnaire. This questionnaire, which was filled in by the students, consists of 10 items regarding students' home and school lives, their perceptions about themselves, attitudes towards mathematics and science lessons, homework and extracurricular activities, computer use, resources related to home learning, and general personal information (Hooper et al., 2013). The items in the TIMSS 2015 student questionnaire data file were determined as gender, absenteeism, nutrition, use of technology at home, use of technology in school, and use of technology in other places variables in line with the relevant literature.

Reliability of measurements: TIMSS 2015 student and teacher surveys include items in which Likerttype grading is used to measure the characteristics thought to be related to science achievement. Analyses based on Item Response Theory were performed by TIMSS experts using ConQuest 2.0 software, and measurements of the structure to be measured were obtained based on the responses given to these questionnaire items. These measurements were determined as a mean of 10 and a standard deviation of two for each structure (Martin, Mullis, Hooper et al., 2016). The scale items determined within the scope of the current research were examined by the TIMSS technical team with the Rasch Partial Credit Model within the framework of Item Response Theory.

Reliability coefficients for each scale were calculated for each country, and principal components analysis of the scale items was performed as evidence that the scales provide comparable measurements between countries. The reports presented as a result of the analyses conducted in this direction showed that the TIMSS 2015 scales were generally at an acceptable level, and Cronbach's Alpha values were higher than .70. The values related to the reliability of the scales used in the current research are given in Table 1 (Martin, Mullis, Hooper et al., 2016).

\section{Data Analysis}


The two-level hierarchical linear modeling (HLM) method was used in the analysis of the data of the study. The first stage of HLM is a preliminary analysis. Accordingly, the student-level variables obtained from the student questionnaire and the classroom level variables obtained from the teacher questionnaire were arranged in accordance with the purpose of the study by applying the following procedures. The assumptions of HLM were tested in the second stage. Data were analyzed by establishing HLM models at the last stage.

\section{Preliminary analyses}

Data editing: The original codes determined for the variables in the data set were re-coded as $X$ for the variables of this research, $W$ for the student level variables, and to express the classroom level variables. Some items in the student and teacher questionnaire were removed from the data in line with the purpose of the research and the relevant literature. The items used in the research are the items determined at student and classroom levels in Table 1. Items of variables with index scores were deleted from the data.

Correlation between variables: Independent variables that are not related to the dependent variable were checked. Correlation values ranged from -.08 to .29 (at .01 significance level). Therefore, the variable was not deleted from the data set.

Multicollinearity: The correlations of the independent variables in the student level were examined, and it was checked whether there was multicollinearity. The fact that this relationship level is . 80 and above indicates that this problem may occur, while the fact that it is .90 and above is important evidence for the multicollinearity problem (Tabachnick \& Fidell, 2001). Correlation values obtained in this direction ranged from -.07 to .34 (at .01 significance level). No variables were deleted from the file according to the results.

Missing value analysis: This section is described in the "sample" section.

Detecting and removing outliers: The differentiation of any subject from the rest of the sample is the basis for the outlier in scientific research. The values of the continuous variables were converted to $\mathrm{Z}$ scores, and it was checked whether there was a value excluded by \pm 4 points in the present study (Mertler \& Vannatta, 2005; Tabachnick \& Fidell, 2001). The sample consisted of 6378 students and 241 teachers as a result of removing the outliers from the data set.

Exploratory analysis: Exploratory analysis was performed for classroom-level variables. Exploratory analysis is one of the options of the HLM program; it is a basis for deciding which variables are appropriate to include in the model. If the absolute value of $t$ obtained in the analysis is greater than 1 , the relevant variable can be included in the analysis (Raudenbush \& Bryk, 2002). Fifteen variables related to science achievement were examined simultaneously, and the t values of 11 variables were found to be significant (ranging from -1.23 to 10.26) in this analysis. All variables with significant $t$ values were included in the model. Variables with an insignificant $t$ value [checking homework in the classroom (0.57), lesson-day life connection (0.96), completing challenging activities (-0.31), explaining thoughts during the lesson (-0.84)] were excluded from the analysis. There were six variables at the student level and 11 variables at the classroom level as a result of the preliminary analysis.

\section{HLM analysis}

HLM is a multi-level regression technique that performs the necessary analyses in accordance with the structure of hierarchical (gradual) data obtained especially in the field of education and includes intertwined random effects (Raudenbush \& Bryk, 2002). The vast majority of the data obtained in social sciences are hierarchical due to the sampling structure or sampling techniques. Students exhibit a hierarchical structure to be clustered in classrooms, classrooms in schools, schools in regions, and regions in countries in the TIMSS application, which is the subject of the current study. The 
hierarchical Linear Model investigates the relationships between the hierarchical levels of simultaneously grouped data and thus makes it more efficient in calculating the difference between variables at levels unlike single-level analysis methods (Raudenbush \& Bryk, 2002). It is recommended to use multi-level models for data analysis in studies where data are obtained from different levels, such as TIMSS, in the literature on this subject (Heck \& Thomas, 2009; Hox, 2002; Raudenbush \& Bryk, 2002). Hox (2002) states that the application of single-level models for data analysis in such studies will cause statistical and conceptual problems.

Single-level analysis methods require the assumptions of independence of observations and homoscedasticity to be met. These assumptions may be violated in the data obtained from large samples. Ozborne (2002) states that the data obtained for different groups in a hierarchical pattern tend to be more similar to each other at the level they are at. For example, students in a certain classroom are more similar to each other because they share the same opportunities compared to students in different classrooms. It is impossible in this case for the observations obtained from the students in the same unit to be completely independent of each other. Therefore, it would be more accurate to use multi-level models in the analysis of data in an intertwined structure in order not to violate the assumption of independence of observations. Another important issue is the violation of the assumption of homoscedasticity (Hox, 2010). The other classroom may be heterogeneous while one classroom shows a homogeneous structure in large samples. Multi-level models allow the intra-group and inter-group variance of the dependent variable to be calculated; therefore, it is possible to understand the effects of the levels.

In addition, the use of single-level analysis methods in the analysis of hierarchical data may cause the standard errors of regression coefficient predictions to be calculated smaller than they should be. This leads to an overestimation of the significance levels of predicted regression coefficients (Raudenbush $\&$ Bryk, 2002). This situation can be eliminated by including a random effect coefficient $\left(u_{\mathrm{qj}}\right)$ at each level in multi-level models. Thus, standard errors can be accurately predicted considering the variability in random effects. This is another advantage of the multi-level model.

"Hierarchical Linear Model was preferred in the analysis of data due to the advantages it provides compared to single-level models on different subjects explained" (Raudenbush \& Bryk, 2002, pp. 36 ), and it is in accordance with the data structure of the current research as a result (Hox, 1995).

Determination of levels in HLM: Determining the level to be addressed in the examination of the relationships between variables is a stage that is considered important and needs attention when working with data showing a hierarchical structure. The number of hierarchical categories used in HLM analysis is used to name the analysis. The variables belonging to the students may be in the student-level; the variables belonging to the classrooms may be in the classroom or school level in the analyses to be made in cases where students are clustered in the classrooms (Nilsen et al., 2016). This is also called Two-Level Hierarchical Linear Modeling due to its two-level data structure (Toraman, Akay, Özdemir, \& Karadağ, 2011). Independent variables withdrawn from the TIMSS 2015 dataset were defined in two main categories as student level and grade level to be included in the HLM analysis in the present study.

Determination of variables of research: It is seen that the student-level and classroom-level variables related to achievement are based on different school learning models in the literature in some of the studies conducted at the international level based on TIMSS (Kyriakides, 2006; Lamb \& Fullarton, 2002; Nilsen et al., 2016; Webster \& Fisher, 2000). There are studies that theoretically benefit from different models in determining the variables discussed at student and classroom levels among the studies based on TIMSS in Turkey (Akyüz, 2006; Aydın, 2015; İpekçioğlu-Önal, 2015). For example, Akyüz (2006) prepared the variables determined from the teacher and student questionnaire in relation to students' mathematics achievements based on the theoretical structure that constitutes the theoretical framework of the TIMSS 1995 study and examined them based on the Survey of Mathematics and Science Opportunities (SMSO). Similarly, Aydın (2015) examined different theoretical models and proposed a new model regarding the effects of student and school-level factors on student achievement. This model was established based on the theoretical assessment framework of TIMSS 2011 implementation. İpekçioğlu-Önal (2015) developed a new model based on previous 
studies on this subject in order to examine student- and teacher-level factors affecting students' science achievement and attitudes towards science. Gender, time allocated to homework, peer bullying, family participation, and educational resources at home were brought together at the student level and selfconfidence in science teaching, commitment to the profession, cooperation with colleagues, emphasis on science experiments, experience, and professional development factors were brought together at the teacher level regarding students' science achievements and attitudes towards science in this model.

Different models have been developed in studies on what factors affect achievement in science, addressing various factors at student and classroom levels in relation to student achievement as a result (Lamb \& Fullarton, 2002). It can be said that only one model cannot fully explain the relationship between student outcomes and many different variables based on this information. It may be statistically and theoretically more useful to choose a framework created based on variables tried and proven with different models in a study to be carried out on this subject (Hox, 2010).

Therefore, different learning models in the literature, the TIMSS assessment framework, and the Conceptional framework of determinants of students' outcomes developed by Nilsen et al. (2016) were examined to decide which variables to include in the student and classroom levels in the current research and the variables of the research were shaped as a result of these reviews. A total of 21 independent variables, 6 at the student level, and 17 at the classroom level were determined based on this. Table 1 contains detailed information about the variables of the study.

Table 1. Variables Determined Before Preliminary Analysis of the Research

\begin{tabular}{|c|c|c|c|c|c|c|}
\hline $\begin{array}{l}\text { Conceptual } \\
\text { Group }\end{array}$ & $\begin{array}{l}\text { Classroom Level (Level-2) } \\
\text { Variables }\end{array}$ & Conversion & TIMSS Code & $\begin{array}{l}\text { Research } \\
\text { Code }\end{array}$ & Reliability* & $\begin{array}{l}\text { Variance } \\
\text { Explained }\end{array}$ \\
\hline \multirow{2}{*}{$\begin{array}{l}\text { School } \\
\text { Environment }\end{array}$} & $\begin{array}{l}\text { Perception of the importance } \\
\text { of school in academic } \\
\text { achievement }\end{array}$ & Yes & ATBG06A-R & W12 & .90 & 45 \\
\hline & $\begin{array}{l}\text { Perception of safe and regular } \\
\text { school structure }\end{array}$ & Yes & ATBG07A-H & W13 & .89 & 57 \\
\hline \multirow{2}{*}{$\begin{array}{l}\text { Working } \\
\text { Conditions }\end{array}$} & $\begin{array}{l}\text { Problems with school } \\
\text { facilities and resources }\end{array}$ & Yes & ATBG08A-G & W14 & .89 & 60 \\
\hline & Difficulties encountered & & ATBG11A-H & W15 & .76 & 35 \\
\hline \multirow{5}{*}{$\begin{array}{l}\text { Teaching } \\
\text { Practices }\end{array}$} & $\begin{array}{l}\text { Teaching limited to student } \\
\text { needs }\end{array}$ & Yes & ATBG15A-G & W16 & .73 & 43 \\
\hline & Homework Given (3) & No & $\begin{array}{l}\text { ATBS06CA- } \\
\text { CB }\end{array}$ & $\begin{array}{l}\text { W18A- } \\
C^{* *}\end{array}$ & - & - \\
\hline & $\begin{array}{l}\text { The importance given to } \\
\text { research }\end{array}$ & Yes & ATBS03A-K & W19 & .88 & 47 \\
\hline & $\begin{array}{l}\text { Participation in } \\
\text { teaching/Quality of teaching } \\
\text { (8) }\end{array}$ & No & ATBG14A-H & $\begin{array}{l}\text { W20A- } \\
\mathrm{H}^{* *}\end{array}$ & - & - \\
\hline & $\begin{array}{lll}\text { Student Level } & \text { (Level-1) } \\
\text { Variables } & & \\
\end{array}$ & & & & & \\
\hline \multirow{4}{*}{$\begin{array}{l}\text { Student } \\
\text { Qualifications }\end{array}$} & Gender & No & ITSEX & $\mathrm{X} 8 * * *$ & & \\
\hline & Absenteeism & No & ASBG08 & $\mathrm{X} 9 * *$ & & \\
\hline & Not having breakfast & No & ASBG09 & $\mathrm{X} 10 * *$ & & \\
\hline & Use of technology (3) & No & ASBG10A-C & $\begin{array}{l}\mathrm{X} 11 \mathrm{~A}- \\
\mathrm{C}^{* *}\end{array}$ & & \\
\hline
\end{tabular}

Models were established with a total of 17 variables, 6 at the student level, and 11 at the classroom level after the preliminary analysis with the variables in Table 1 . The dependent variable of the study is TIMSS 2015 science achievement scores. Among the independent variables, those with similar characteristics were divided into conceptual groups based on the literature and in terms of interpreting the results. The student level consists of 1 , and the classroom level consists of 3 conceptual groups as shown in Table 1. 
The scales used in TIMSS applications related to the variables of the research were scored as 1-3 as a result of questionnaires or index data consisting of 1-4 scored response categories [strongly agree (1), slightly agree (2), disagree (3), strongly disagree (4)] [for example less (3), moderately (2), more (1)]. However, these scores were converted by taking the cut-off points into account by calculating the actual ranges in order for the data to be used in the analysis (Aydin, 2015). Analyses were conducted with continuous values obtained from converted scales in this study. This approach can prevent a number of statistical difficulties in identifying the measured psychological trait with numerical data and in particular, its interpretation. For example,

9.6 and 8 cut-off points were determined for the peer bullying scale, which was constantly converted into a form by calculating the actual ranges. The levels of peer bullying of students were defined as almost never $(<8)$, once a month $(<9.6$ and $>8)$ and once a week (> 9.6). (Martin, Mullis, Hooper et al., 2016, p. 15.89)

The use of these defined values (for example, peer bullying variable) provides convenience in terms of statistical identification and interpretation of the psychological structures such as attitude, value, etc. targeted to be measured.

The variable related to gender is categorical. Each item is considered as a separate variable in the measurements related to some variables that are not continuously converted into forms and have implicit characteristics (homework given, use of technology, and participation in teaching/quality of teaching). Measurements of some variables are discontinuous. Descriptive statistics regarding the variables included in the HLM analysis are given in Table 2.

Table 2. Descriptive Statistics on Variables Included in HLM Analysis

\begin{tabular}{|c|c|c|c|c|c|}
\hline Variables & $\mathrm{N}$ & Mean & SD & Minimum & Maximum \\
\hline $\mathrm{X} 8$ & 6378 & 1.51 & 0.50 & 1.00 & 2.00 \\
\hline X9 & 6378 & 3.38 & 0.96 & 1.00 & 4.00 \\
\hline X10 & 6378 & 1.74 & 1.04 & 1.00 & 4.00 \\
\hline $\mathrm{X} 11 \mathrm{~A}$ & 6378 & 2.34 & 1.21 & 1.00 & 4.00 \\
\hline $\mathrm{X} 11 \mathrm{~B}$ & 6378 & 2.77 & 1.29 & 1.00 & 4.00 \\
\hline $\mathrm{X} 11 \mathrm{C}$ & 6378 & 2.59 & 1.20 & 1.00 & 4.00 \\
\hline W12 & 241 & 9.29 & 1.97 & 2.82 & 15.83 \\
\hline W13 & 241 & 9.67 & 2.16 & 3.75 & 13.41 \\
\hline W14 & 241 & 8.90 & 2.23 & 3.19 & 13.57 \\
\hline W15 & 241 & 1.05 & 0.93 & 0.00 & 3.00 \\
\hline W16 & 241 & 8.78 & 1.72 & 3.80 & 14.51 \\
\hline W18A & 241 & 1.25 & 0.45 & 1.00 & 3.00 \\
\hline W18B & 241 & 1.52 & 0.54 & 1.00 & 3.00 \\
\hline W18C & 241 & 1.18 & 0.39 & 1.00 & 3.00 \\
\hline W19 & 241 & 11.11 & 2.06 & 7.30 & 15.55 \\
\hline W20B & 241 & 1.344 & 0.60 & 1.00 & 3.00 \\
\hline W20C & 241 & 2.49 & 0.75 & 1.00 & 4.00 \\
\hline W20E & 241 & 1.34 & 0.60 & 1.00 & 4.00 \\
\hline W20F & 241 & 1.48 & 0.75 & 1.00 & 4.00 \\
\hline W20G & 241 & 1.60 & 0.80 & 1.00 & 4.00 \\
\hline PV1(ASSSCI01) & 6378 & 484.33 & 91.13 & 142.40 & 754.79 \\
\hline PV2(ASSSCI02) & 6378 & 482.38 & 92.36 & 150.67 & 745.23 \\
\hline PV3(ASSSCI03) & 6378 & 482.26 & 92.69 & 136.74 & 746.52 \\
\hline PV4(ASSSCI04) & 6378 & 481.30 & 93.80 & 69.90 & 846.24 \\
\hline PV5(ASSSCI05) & 6378 & 484.62 & 93.39 & 103.62 & 781.64 \\
\hline
\end{tabular}

Assumptions of HLM: The assumptions for HLM analysis were checked after the completion of the preliminary analyses. The first assumption for Level-1 in HLM is about the normality of residuals. Kolmogorov-Smirnov test results of the residual files created in the SPSS software were found to be significant at this stage $(p<.001)$. It is, in this case, interpreted as that the data differ from the normal distribution (Mertler \& Vannatta, 2005). Afterward, skewness and kurtosis coefficients were examined. These values are calculated as zero in normally distributed data. However, the fact that these values are between \pm 1 is interpreted as that the distribution does not deviate excessively from 
normal (Çokluk et al., 2018; Kim, 2013). Skewness and kurtosis values of the data were calculated as $(-0.225)$ and $(0.250)$ respectively. It was observed in this case that the data showed normal distribution. Another statistical process related to the normality of 1 st level errors is the examination of the histogram of the data by drawing it on the normal curve. The histogram indicates the distribution of in-school errors is approximately normal, in which case the normality count can be advocated. The QQ graph of the data can also be examined, especially in 100 and larger samples, to check the normality count. The points in Q-Q Plot were seen as a line in the focus of diagonals in the process. This figure is interpreted as an image of the normal distribution (Mertler \& Vannatta, 2005). Finally, the Level-1 residual homoscedasticity was checked. The ellipse shape showed that the residual variances of Level1 were homogeneous when the Scatter Plot Diagram obtained as a result of the SPSS procedure was examined. Test of Homogeneity was also applied in the HLM software regarding homoscedasticity. It is $\chi^{2}=274.93, d f=239, p>.001$ according to the results of this test. The fact that the test for homoscedasticity of Level-1 variances was not found to be significant indicates that variances were distributed homogeneously between Level-2 units. Therefore, it was observed that this assumption was made regarding the data of the current research. It was observed as a result that the residuals for Level-1 showed a close to normal and homogeneous distribution; the variables were independent of the error term $r_{\mathrm{ij}}$ and random effects at other levels.

Scatter graphs were obtained using residual files in SPSS in the first stage of the multivariate normal distribution of errors, which is the first assumption for Level-2. The MDIST (Mahalanobis Distance) graph for each school gave the deviation of residuals from normality. Q-Q and P-P graphs were examined for residuals of intersection and slope models. The MDIST vs. CHIPT graph is expected to resemble a 45-degree line in the figures obtained for the normality assumption of the slope coefficients of the cut-off point and variables at this level. The obtained graph resembles a 45-degree line. Furthermore, the Q-Q graph for the intersection model was found to be approximately linear. Thus, it is seen that subordination is defendable. In addition, it was seen that the residual values of the secondlevel cut-off point coefficients were normally distributed with multivariates when the Q-Q Plots of the slope coefficients of the classroom level variables were examined. In addition, the fact that the Kolmogorov-Smirnov and Shapiro-Wilk test results regarding the slope coefficients of the variables were found to be significant explained that the hypothesis was acceptable for the relevant coefficients and that the data showed normal distribution.

As a result, it was found that the slope coefficients of the cut-off point and variables at this level showed a normal distribution for Level-2. The variables are independent of the error term $u_{0 \mathrm{j}}$. In addition, Level-2 errors show multiple normalities with a mean of zero.

Models for responding to the research problems were analyzed after providing the assumptions. The HLM models tested within the scope of this research are given below:

1) One-Way Analysis of Variance Random Effects Model (ANOVA Model): It is checked whether HLM is appropriate in the analysis of the data while answering the question How much of the differences in students' science achievement arise from the difference between classrooms? with this model at the same time. There are no explanatory variables for student or classroom levels in the model (Hox, 2002). The variance of the dependent variable is divided into two as inter-group and intra-group variance in the one-way analysis of variance. The Level-1 equation for this model is:

$$
Y_{i j}=\beta_{0 j}+r_{i j}
$$

The science achievement of the student $i$ in the classroom $j\left(Y_{\mathrm{ij}}\right)$ is predicted in this equation. $\beta_{0 \mathrm{j}}$ refers to the mean science achievement score of the class $j, r_{\mathrm{ij}}$ refers to the error score of the student $i$ in the class $j$, that is, the difference of the student $i$ from the mean science score in the class $j$. It is assumed that each error score at the student level is normally distributed with the 0 mean and constant Level-1 $\left(\sigma^{2}\right)$ variance. The Level-2 equation for this model is:

$$
\beta_{0 j}=\gamma_{00}+u_{0 j}
$$

The mean overall science achievement score of the classrooms $\gamma_{00}$ indicates the error score of the $u_{0 j}$, classroom $j$ in the equation where the intersection coefficient $\left(\beta_{0 \mathrm{j}}\right)$ at the first level of the model is 
taken as the dependent variable; that is, it is interpreted as the difference of the mean science achievement of the classroom $j$ from the mean overall science achievement. It is assumed that $u_{0 j}$ shows a normal distribution with the mean 0 and the variance $\tau_{00}$. $u_{0 \mathrm{j}}$ getting closer to zero means that the variability among the classrooms is very low.

Unified model:

$$
Y_{i j}=\gamma_{00}+u_{0 j}+r_{i j}
$$

Inter-school and intra-school correlation coefficient (Intra-Classroom Correlation, [ICC]) $p$ is calculated to determine how much of the variance in the dependent variable originates from the first level and how much originates from the second level using the following parameters.

$$
\begin{gathered}
\rho \text { (inter-class })=\tau^{00} /\left(\tau^{00}+\sigma^{0}\right) \\
\rho(\text { intra-classroom })=\sigma^{2} /\left(\tau^{00}+\sigma^{2}\right)
\end{gathered}
$$

2) The Model with Means as Dependent Variables was established to answer the second question of the research. The Level-1 equation of this model is the same as the ANOVA model, and there are no student level variables. Grade variables were added to Level-2 to show the extent to which classroom characteristics predict student achievement.

Centering was performed to eliminate the bias caused by the multicollinearity problem in the installation of models (Raudenbush \& Bryk, 2002). Group-mean centering was performed for the continuous variables at the student level, and grand-mean centering was performed for the continuous variables at the classroom level while centering was not performed for the categorical variables at both levels. Accordingly, the equations for the model in which the means are dependent variables are as follows:

$$
\begin{gathered}
Y_{i j}=\beta_{0 j}+r_{i j} \\
\beta_{0 j}=\gamma_{00}+\gamma_{01} *\left(W 20 B_{j}\right)+\gamma_{02} *\left(W 18 A_{j}\right)+\gamma_{03} *\left(W 18 B_{j}\right)+\gamma_{04} *\left(W 14_{j}\right)+u_{0 j}
\end{gathered}
$$

*General mean centering was performed for these variables

3) Random Coefficients Regression Model: Student variables related to science scores are assigned to the first level, and it is determined which student-level variable affects science achievement score in this model established to answer the third research question. There are no classroom-level variables in the model (Raudenbush \& Bryk, 2002). The Level-2 equation is the same as in the ANOVA model. The coefficients of the student variables are interpreted as the change in the mean school achievement scores caused by one-unit variability in the independent variable at the 1 st level of the model. The equations for the model are as follows:

$$
\begin{gathered}
Y_{i j}=\beta_{0 j}+\beta_{1 j^{*}} X 9_{i j)}+\beta_{2 j^{*}} X 10_{i j)}+\beta_{3 j^{*}} X 11 B_{i j)}+\beta_{4 j^{*}} X 11 C_{i j)}+r_{i j} \\
\beta_{0 j}=\gamma_{00}+u_{0 j} \\
\beta_{1 j}=\gamma_{10}+u_{1 j} \\
\beta_{2 j}=\gamma_{20}+u_{2 j} \\
\beta_{3 j}=\gamma_{30}+u_{3 j} \\
\beta_{4 j}=\gamma_{40}+u_{4 j}
\end{gathered}
$$

*Group-mean centering was performed for these variables.

\section{RESULTS}

One-Way Analysis of Variance Results Related to the Random Effects Model 
The results of the analysis are given in Table 3. The weighted least squares prediction for the overall science achievement mean is 481.91 , and the standard error of the prediction is 3.98 when Table 3 is examined. It can be said that the actual value of the overall science achievement mean is $95 \%$ probability in the range of $479.69-483.86$ points when the $95 \%$ confidence interval for the student overall science achievement mean is calculated [\%95CI $\left.\left(\gamma_{o o}\right)=\gamma_{00} \pm(1.96)(\mathrm{SE})\right]$.

$\gamma_{\mathrm{oo}} \pm(1.96) *(\mathrm{SE})=481.91 \pm(1.96) *(3.91)=479.69-483.86$

Table 3. One-Way Analysis of Variance Random Effects Model Analysis Results

\begin{tabular}{|c|c|c|c|c|}
\hline Fixed Effect & Coefficient & $t$ & Standard Error (SE) & Approximate $d f$ \\
\hline Overall science achievement mean, $\gamma 00$ & $481.91 *$ & 120.92 & 3.98 & 158 \\
\hline Random Effect & Variance & & Standard Deviation & \\
\hline Level-2 Error Term, $u 0 j$ & 2983.99 & & $54.63^{*}$ & 240 \\
\hline Level-1 Error Term, rij & 5498.73 & & 74.15 & \\
\hline
\end{tabular}

${ }^{*} p<.001$

In Table 3, the intra-classroom variability $\left(r_{\mathrm{ij}}\right)$ was 5498.73 , and the inter-classroom variability $\left(u_{0 \mathrm{j}}\right)$ was 2983.99 regarding the mean science achievement score. The fact that the predicted value of interclassroom variability $\left(u_{0 \mathrm{j}}\right)$ was found to be significantly greater than zero $(p<.001)$ indicates significant differences between the mean science achievements of the classrooms.

It can also be calculated through this model how much of the difference in science scores can be explained by student level, and how much can be explained by classroom-level variables. The intragroup correlation coefficient for science achievement scores was calculated by dividing the interschool variance in Table 3 by total variance (Raudenbush \& Bryk, 2002).

$$
\rho=\sigma^{2} /\left(\tau_{00}+\sigma^{2}\right)=5498.73 /(2983.99+5498.73)=0.65
$$

This result shows that $65 \%$ of the difference in science scores is due to the difference between students, and $35 \%$ is due to the difference in mean science achievement between classrooms. Most of the variability in students' science achievement scores is due to differences between students.

\section{Results on the Model with Means as Dependent Variables}

This model included [perception of the importance of school in academic achievement (W12), perception of safe and regular school structure (W13), problems related to school facilities and resources (W14), difficulties encountered (W15), teaching limited to student needs (W16), giving feedback to science homework (W18A), discussing science homework in the classroom (W18B), the importance given to research (W19), explaining the answers (W20B), using interesting materials (W20C), new content-present content connection (W20E), classroom discussions (W20F), and deciding on problem-solving processes (W20G)]. Variables whose effects were not significant were removed from the model as a result of the first analysis. Accordingly, their relationship with W12, W16, W20C, W20F, and W20G science achievement scores is positive but not significant. Similarly, variables W13, W15, W20E were found to have non-significant negative correlations with science achievement scores. Variables W20B, W18A, W18B, and W14 were included in the final analysis. The equation for the final model is given below:

$$
\beta_{0 j}=\gamma_{00}+\gamma_{01 *}\left(W 20 B_{j}\right)+\gamma_{02 *}\left(W 18 A_{j}\right)+\gamma_{03 *}\left(W 18 B_{j}\right)+\gamma_{04 *}\left(W 14_{j}\right)+u_{0 j}
$$

*general mean centering was performed.

$\gamma_{00}$ is the corrected mean overall science achievement of the classrooms in this equation. $\gamma_{01}$ is interpreted as the effect of explaining the answers given in the classroom; $\gamma_{02}$ is interpreted as the effect of giving feedback to the homework; $\gamma_{03}$ is interpreted as the effect of discussing the homework in the classroom on the corrected mean science achievement. $u_{0 \mathrm{j}}$ (Level-2 error term) is expressed as the 
difference of the mean science achievement score of the classroom $\mathrm{j}$ from the mean overall science achievement score when the variables in the model are taken under control.

Table 4. Model Analysis Results with Means as Dependent Variables

\begin{tabular}{lrrrrr}
\hline Fixed Effects & Coefficients & $\begin{array}{r}\text { Standard } \\
\text { Error }\end{array}$ & $t$ & $s d$ & $\begin{array}{r}\text { Effect } \\
\text { Size }\end{array}$ \\
\hline Mean classroom mean, $\gamma_{00}$ Intersection & 481.88 & 3.66 & 131.67 & 112 & \\
W20B, $\gamma_{01} *$ & -14.68 & 5.75 & -2.57 & 236 & -.30 \\
W18A, $\gamma_{02}^{*}$ & 19.36 & 8.26 & 2.34 & 236 & .39 \\
W18B, $\gamma_{03}^{*}$ & -14.74 & 6.90 & -2.13 & 236 & -.30 \\
W14, $\gamma_{04}^{*}$ & 9.91 & 1.50 & 6.57 & 236 & .20 \\
\hline \multirow{2}{*}{ Random Effects } & Standard & Variance & \multirow{2}{*}{$s d$} & \multirow{2}{*}{$\chi^{2}$} \\
\hline Level-2 Error Term, $u_{0 \mathrm{j}}$ & Deviation & components & \multicolumn{2}{c}{} \\
Level-1 Error Term, $r_{\mathrm{ij}}$ & 48.816 & 2383.01 & 2982.37 & \\
\hline
\end{tabular}

*p<.001

It is seen that when the other variables in the model are taken under control, the effect of the explanation of the answers given by the students (W20B) on the science achievement scores is predicted to be negatively significant $\left(\gamma_{01}=-14.68, t=-2.57, p<.001\right)$. Accordingly, the frequent explanation of the answers in the teaching process in the classroom negatively affects the science achievement scores of the schools. The mean science achievement score of these schools is about 15 units less compared to the schools where the answers are explained less. Similarly, the effect of discussing science homework in the classroom (W18B) on science achievement scores was predicted to be negatively significant when the other variables in the model were taken under control $\left(\gamma_{03}=-\right.$ $14.74, t=-2.13, p<.001)$. Accordingly, it is seen that the science achievement scores of the schools where the students who frequently discuss science homework in the classroom are 14.749 units lower compared to the science achievement scores of the schools where the homework is not discussed much.

The effect of giving feedback to science homework (W18A) on the science achievement scores of the students is predicted to be positively significant when the other variables in the model are taken under control, unlike these results $\left(\gamma_{02}=19.36, t=2.34, p<.001\right)$. Accordingly, it is seen that the feedback given to the science homework in the teaching process in the classroom positively affects the science achievement scores of the schools. Another variable with a positive effect on science achievement scores is problems with school facilities and resources (W14) $\left(\gamma_{04}=9.91, t=6.57, p<.001\right)$. Accordingly, it is seen that the science achievement of the schools is positively affected by this situation as the perception levels of the teachers about the lack of opportunities and resources of the schools they work affect the teaching when the other variables in the model are taken under control.

Effect size calculation was made in order to give an idea about whether the interpretations made in line with the variance rates and correlational relationships obtained as a result of the analysis indicate significance for daily life. Accordingly, the effect size was calculated by dividing the constant effect coefficients obtained by the analysis performed at each level by the standard deviation of the residual value at the relevant level. The effect size coefficient .41 indicates the minimum effect (Ferguson, 2009). It is seen that these values are less than .41 when the calculated effect sizes are examined. However, it can be said that these variables may cause a change that can be felt in practice on science achievement considering that even the effect sizes calculated at the .1 level in the studies conducted with large samples may contribute to the developments in the field of education (Glass, McGaw, \& Smith, 1981). For example, a standard deviation increase in giving feedback to science homework is expected to create an increase of 0.39 standard deviation in the science achievement mean when the other variables in the model are taken under control. It can be said that the science achievement scores of the schools whose homework is discussed in the classroom are less than 0.30 standard deviations compared to the schools whose homework is not discussed.

Finally, the inter-classroom variance component for science achievement scores was predicted at 2983.99 in the ANOVA model. It was predicted as 2383.011 as the inter-classroom variance 
component with the addition of class-level variables to the model. Therefore, in-classroom variables explained $20 \%$ of the observed variance in achievement scores [(2983.99-2383.011)/2983.99].

\section{Random-Coefficients Results Related to the Regression Model}

This model included variables such as gender (X8), absenteeism (X9), not having breakfast (X10), use of technology at home (X11A), use of technology in school (X11B), and use of technology in other places (X11C). Variables whose effects were not significant were removed from the model as a result of the first analysis. Accordingly, the strong positive relationship of X8 with science achievement and the negative relationship of X11A with science achievement score was not found to be statistically significant. Variables X9, X10, W11B, and X11C were included in the final analysis. The equation for the final model is given below:

$$
Y_{i j}=\beta_{0 j}+\beta_{1 j *} X 9_{i j}+\beta_{2 j *} X 10_{i j}+\beta_{3 j *} X 11 B_{i j}+\beta_{4 j *} X 11 C_{i j}+r_{i j}
$$

*group mean centering was performed.

This equation shows the science achievement score of the student $i$ in the $Y_{\mathrm{ij}}, j$ classroom and the mean science achievement score of the $\beta_{0 \mathrm{j}}$, classroom $j . \beta_{1 \mathrm{j}}$ is expressed as a unit change in absenteeism in the classroom $j$ (when the other variables in the model are taken under control); $\beta_{2 \mathrm{j}}$, is expressed as a unit change in nutrition in the classroom $j$ (when the other variables in the model are taken under control); $\beta_{3 j}$, is expressed as a unit change in technology use in the classroom $j$ (when the other variables in the model are taken under control); $\beta_{4 \mathrm{j}}$, is expressed as a unit change in technology use in the classroom $j$ (when the other variables in the model are taken under control); and these are expressed as a change in the classroom mean science achievement scores.

Table 5. Random-Coefficients Results of Regression Model Analysis

\begin{tabular}{|c|c|c|c|c|}
\hline Fixed Effects & Coefficients & Standard Error & $t$ & Effect Size \\
\hline $\begin{array}{l}\text { Cut-off point } 1, \beta_{0} \text { Overall science achievement } \\
\text { mean, } \gamma_{00} *\end{array}$ & 481.89 & 3.98 & 120.84 & --- \\
\hline X9 Slope, $\beta_{1}$ Cut-off point $2, \gamma_{10} *$ & 18.26 & 1.44 & 12.60 & 0.26 \\
\hline X10 Slope, $\beta_{2}$ Cut-off point $2, \gamma_{20} *$ & -2.90 & 1.13 & -2.55 & -0.00 \\
\hline X11B Slope, $\beta_{3}$ Cut-off point $2, \gamma_{30} *$ & 8.90 & 1.05 & 8.46 & 0.01 \\
\hline X11C Slope, $\beta_{4}$ Cut-off point $2, \gamma_{40} *$ & -2.67 & 1.12 & -2.37 & -0.00 \\
\hline Random Effects & $\begin{array}{r}\text { Standard } \\
\text { Error } \\
\end{array}$ & $\begin{array}{r}\text { Variance } \\
\text { Components } \\
\end{array}$ & $s d$ & $X^{2}$ \\
\hline Level-2 Error Term, $u_{0 j}$ & 54.83 & 3007.17 & 223 & $4003.17 *$ \\
\hline X9 Slope, $u_{1}$ & 8.32 & 69.25 & 223 & 278.18 \\
\hline X10 Slope, $u_{2}$ & 6.86 & 47.14 & 223 & 255.73 \\
\hline X11B Slope, $u_{3}$ & 6.80 & 46.35 & 223 & 295.48 \\
\hline X11C Slope, $u_{4}$ & 6.06 & 36.83 & 223 & 254.55 \\
\hline Level-1 Error Term, $r_{i j}$ & 69.93 & 4891.49 & & \\
\hline
\end{tabular}

Table 5 it is seen that the variable with the highest effect on science scores is absenteeism (X9) when examined. The effect of absenteeism on science achievement scores was predicted to be positive and significant when the other variables in the model were taken under control $\left(\gamma_{10}=18.26, \mathrm{SE}=1.44, p\right.$ $<.001$ ). Accordingly, the score of a student who has almost no absenteeism can be interpreted as 18.27 units more than the science score of a student who has frequent absenteeism. Use of technology in school (X11B) is another variable with a high impact on science achievement scores. The coefficient $\left(\beta_{3}\right)$ was statistically significant $(p<.001)$. It can be said that a unit increase in the use of technology in the school (high scores taken from the scale mean low use) will create an increase of 8.90 units in the science achievement scores of the students when the other variables in the model are taken under control. The effect of not eating breakfast (X10) on science achievement scores was predicted to be negative and significant $\left(\gamma_{20}=-2.90, \mathrm{SE}=1.13, p<.001\right)$. Accordingly, it can be interpreted that the mean science achievement of the students who have almost no breakfast on the days they go to school 
is 2 units less compared to the students who have breakfast every day and go to school. Finally, the effect of technology use in other places (X11C) on science scores was predicted to be negative and significant when the other variables in the model were taken under control. It can be said that there will be a decrease of 2.67 units in the science achievement scores of the students as the use of technology in other places (high scores taken from the scale indicate low use) increases based on this when the other variables in the model are taken under control.

It is said that an increase in a standard deviation in absenteeism will create an increase of 0.26 standard deviation in the science achievement mean, and an increase in a standard deviation in using technology in school will create an increase of 0.01 standard deviation in the science achievement mean when the calculated effect sizes are examined. A standard deviation increase in non-breakfast will result in a 0.00 standard deviation decrease in science achievement score. Similarly, a standard deviation increase in technology use elsewhere will create a 0.00 standard deviation decrease in science achievement.

It was determined that the random effect of variance was significant in terms of classroom level when the variance components related to the model were examined $\left(X^{2}=3007.17, \mathrm{sd}=223, p<.001\right)$. Differentiation between classrooms in terms of mean science scores is indiscriminate when studentlevel variables are added. The indiscriminate effects of slopes of absenteeism, not having breakfast, use of technology in school, and use of technology in other places were found to be significant according to Table $5(p<.05)$. This situation reveals that the relationship between the mean science scores of the classrooms and the variables of non-attendance and use of technology in school varies statistically significantly between the classrooms.

The student-level residual variance (4891.49) is smaller compared to the variance (5498.73) obtained in the ANOVA model. This result shows that the difference between students in science achievement scores decreases with the addition of student-level variables. Student-level variables explained $11 \%$ of the observed variance in achievement scores.

Reliability values for Level-1 coefficients were calculated to determine whether the values obtained from the sample were a reliable predictor of the actual value. The results of the HLM analysis are as follows:

Table 6. Reliability Values Regarding Level-1 Random Coefficients

\begin{tabular}{lr}
\hline Level-1 Random Coefficients & Reliability Predictions \\
\hline Mean Science Achievement, $\gamma_{00}$ & .93 \\
$\mathrm{X} 9, \gamma_{10}$ & .19 \\
$\mathrm{X} 10, \gamma_{20}$ & .16 \\
$\mathrm{X} 11 \mathrm{~B}, \gamma_{30}$ & .19 \\
$\mathrm{X} 11 \mathrm{C}, \gamma_{40}$ & .15 \\
\hline
\end{tabular}

Reliability predictions provide information on whether Level-1 coefficients change randomly, constantly, or incidentally. These coefficients do not change randomly or may be constant if the reliability of Level-1 coefficients is below .05 (Acar, 2013; Raudenbush \& Bryk, 2002). The high reliability of the constant (.93) indicates that the science mean obtained from the sample is a reliable predictor of the actual school mean, considering Table 6 . The reliability of these variables was not found to be very high when the predictions of absenteeism, not having breakfast, use of technology in school, and use of technology in other places were examined. However, it can be said that these variables, albeit at a low level, are reliable predictors of science achievement. In addition, the reliability predictions of these variables being greater than .05 indicates that these coefficients change randomly between schools.

\section{DISCUSSION and CONCLUSION}

The factors originating from students and classrooms, which are thought to affect the science achievements of 4th-grade students in a large-scale application, were discussed together in this study. Therefore, the research is important in terms of contributing to the large-scale evaluation literature, 
which has an important place in terms of education systems. It was seen as a result of the HLM analysis that teachers' perception had a statistically significant effect on science achievement means at the classroom level in terms of explaining the answers given by the students, giving feedback to science homework, discussing science homework in the classroom, and problems related to school facilities and resources. On the other hand, teachers' perception of the importance of school in academic achievement, teaching limited to student needs, using interesting materials, classroom discussions, deciding on problem-solving processes, teachers' perception of safe and regular school structure, difficulties faced by teachers, effects of the new content-present connection on science achievement means were not found to be significant. The effects of gender of students and their use of technology at home on science achievement means were not statistically significant at the student level. However, not having breakfast, absenteeism, use of technology in school, and use of technology in places other than school and home were found to have a significant effect on science achievement mean. Figure 1 was arranged regarding the determinants of 4th-grade TIMSS science achievement at student and classroom levels based on the results of the research.

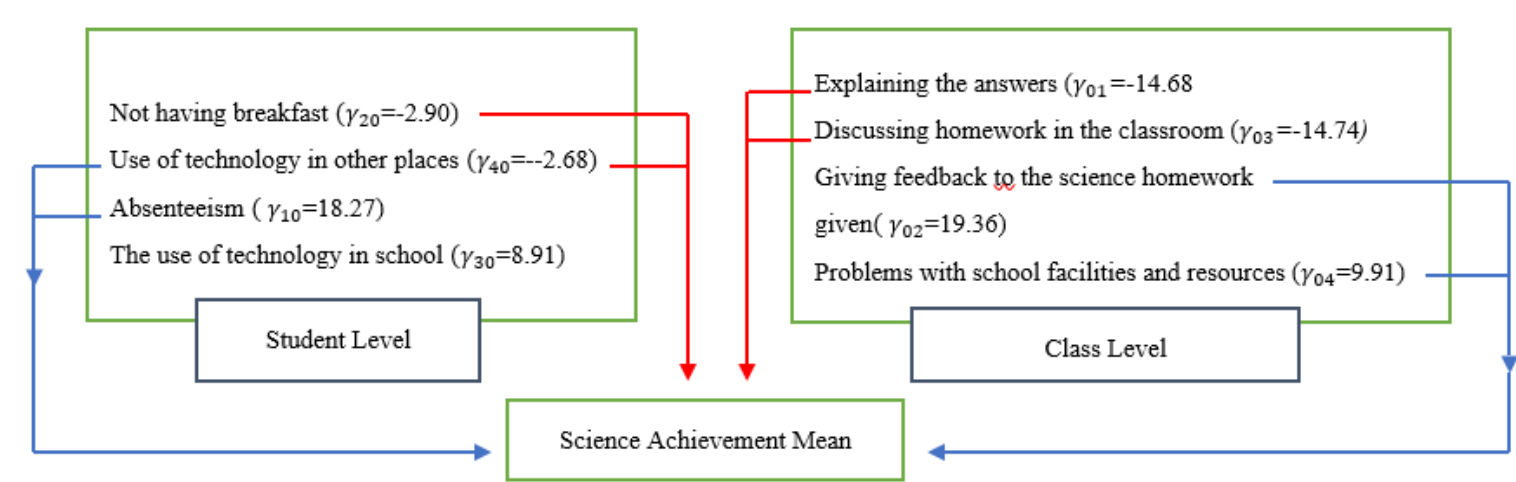

Figure 1. Determinants of 4th Grade TIMSS Science Achievement at Student and Classroom Levels

It was found in the study that $65 \%$ of the differences in science achievement scores of students are due to the difference between students, and 35\% is due to the difference between classrooms. Most of the variability in achievement is due to differences between students. Meta-analysis studies on this subject (Hattie, 2009; Sirin, 2005) show that predictions of differences between schools in student achievement are divided into two. It is stated in some studies that most of the differences in student achievements are explained by school level (İpekçioğlu-Önal, 2015; Mohammadpour \& Abdul Ghafar, 2014; Özgen, 2009; Y1lmaz \& Aztekin, 2012). The results of some other studies support the results that the source of the differences in student achievements is explained by the student level as in the results of the current study (Akyüz \& Berberoğlu, 2010; Akyüz-Aru \& Kale, 2019; Atar \& Atar, 2012; Aydın, 2015; İpekçioğlu-Önal, 2015; Ryoo, 2001; Sevgi, 2009).

The contribution of class-level variables was found to be important in explaining the inter-school variance related to science achievements. The explanation of the answers given by the students in the lessons explained approximately $20 \%$ of the observed variance in teachers' perception and achievement scores in terms of giving feedback to science homework, discussing science homework in the classroom, and problems related to school facilities, and resources. Wenglinsky (2000) states that it is important to investigate the determinacy of variables related to in-classroom processes on student achievement, and results showing significant effects such as the effect of family or student characteristics on achievement can be obtained but the effects of in-classroom processes on achievement are generally ignored in the literature. The results confirm Wenglinsky's (2000) claim considering the magnitude of the explanation rate of the variance at the relevant level.

The variable with the greatest effect on the mean science achievement of the schools at the classroom level is giving feedback to the science homework given considering the effect sizes among the variables used in the study. The most prominent features of the classrooms in which a supportive 
atmosphere is created by meeting the psychological needs of the students in the classroom are the continuous increase in achievement measurements. It is generally known in these classrooms that teachers are willing to give positive feedback and empathy to their students and create environments that will enable students to study autonomously by guiding them (Ryan \& Deci, 2000). Therefore, giving feedback to homework in the classroom may be a factor that reassures students mentally and psychologically. The student can see the deficiencies and mistakes, learn different solutions, and relax knowing that they can meet with the teacher with the feedback on the homework at the end of the process. It can be said that being appreciated by the teacher in return for their efforts will positively affect achievement if it is considered psychological support. Zhu and Leung (2012) stated that the time allocated to homework showed significant relationships with achievement in a study on homework practices in the classroom. It is important how this allocated time is spent. Akyüz (2006) revealed that emphasizing homework and checking homework have a positive effect on student achievement. Therefore, the importance of feedback emerges in teachers' planning for homework.

It is interesting to see that discussing homework in the classroom has a significant negative effect on achievement. The science achievement scores of the schools where the students who frequently discuss science homework in the classroom were found to be lower compared to the science achievement scores of the schools where the homework is not discussed much according to the results. Discussing homework in the classroom can be considered together with giving feedback on the homework. Today, it is known that homework is still a frequently used learning tool by teachers regardless of age and achievement difference within and between classrooms (Trautwein, 2007; Won \& Han, 2010). However, the use of homework in the classroom can have a negative impact on achievement in some cases. This issue can be evaluated in terms of the psychology of the student. The discussions in the classroom about the given homework necessitate the student to be more active when the issue of giving feedback to the student about the homework is considered as a process in which the teacher is more active, and the student is passive. Discussion can be on the way the student does the homework, the way they think, the approach to the homework, and especially on mistakes. The teacher's reactions and the way they direct the process are very important. Ryan and Deci (2000) state that giving positive feedback and empathy to the students of the teachers is important in creating a supportive classroom climate by meeting the psychological needs of the students in the classroom in this case. The psychology of a 9-10-year-old student in the 4th grade may be prone to perceive the discussion of mistakes differently in the classroom; therefore, the negative interaction of achievement with discussing the homework can be evaluated within this framework.

Science lessons are processes that by their natures require the student to be curious, to question, to search for answers, to take responsibility for learning with confidence. Therefore, it would be appropriate to start these lessons with problems, dilemmas, and questions for students (Hiebert et al., 1997). van de Valle, Karp, and Bay-Williams (2010) state that justification should be a fundamental part of science lessons. Teachers have important duties at this point. The language and expression that teachers will use will be an important determinant of students' willingness to express their ideas. The results of the research showed that the more students were directed to explain their answers in the classroom, the more they failed the science lesson. Therefore, these results can be evaluated in terms of the language used by the teachers.

Deci and Ryan (1985) emphasize that the teacher plays a major role in meeting a number of psychological needs of students, such as interaction within the classroom. Students' perceptions of these efforts are more important even though teachers report that students make efforts to meet these psychological needs (Daniels \& Perry, 2003). The class-level results of the research emphasize the importance of these perceptions. It can also be said that the attitude of teachers in supporting the explanation of the answers may cause students to be psychologically worried about explaining the answers they give, especially, in the classroom or to experience morale disorder. Therefore, performance is adversely affected by this process.

The result of the research about the school resources is that the science achievement of the schools is positively affected by this situation as the perception levels of the teachers about the lack of opportunities and resources of the schools they work affect the teaching. It can be evaluated 
psychologically even though this result is interesting. It can be said that this situation indirectly affects student achievement due to the negativities caused by teachers' perceptions, even if not directly based on the fact that teachers feel happier in environments where working conditions are good (Hooper et al., 2013; World Bank, 2011) when the resource shortage is evaluated under conditions. It can be seen that teachers see and enlarge some problems arising from the management and internalize them in a way that adversely affects classroom achievement whereas there are also studies showing that teachers are not affected by this (Bénabou, Kramarz, \& Prost, 2009; Wößmann, 2003). However, it can be interpreted that they do not reflect it to the teaching process and solve it with their special efforts even though teachers see resource shortage as a problem according to the results of the study. It can be seen in such cases that teachers overcome resource shortages with the available facilities in cooperation with their students.

Absenteeism was the variable that contributed the highest level to explaining the variance seen in achievement scores considering the results of the study at the student level. There are studies on absenteeism in parallel with the results of the current study. Alexander and Hicks (2015) found a significant and positive relationship between absenteeism and achievement scores of 383 students. The academic performance of the students who attend the lesson regularly is higher compared to that of the absent students according to the results of the study. Similarly, absenteeism negatively affects students' grades according to the results of Khalid's (2017) study with 119 participants. Absenteeism is an important issue consisting of different components, especially the psychological background of students. Studies generally focus on chronic absenteeism, and the results show that achievement decreases significantly as students' absenteeism rates increase. However, Cattan, Kamhöfer, Karlsson and Nilsson (2017, p. 47) state that "the studies in the literature on this subject are insufficient".

Another result is that this situation of students coming to school without breakfast negatively affects their academic performance. There are studies in the literature mentioning a positive but low level of relationship between nutrition and academic achievement (Dwyer, Sallis, Blizzard, Lazarus, \& Dean, 2001; Keeley \& Fox, 2009). Shaw, Gomes, Polotskaia and Jankowska (2015) state that the controllable aspects of student health are nutrition, healthy weight preservation, and physical equivalence with their peers. It is shown that students with poor health are more likely to fail at school, fail the class, and drop out of school. Kolasa et al. (2018) state that many studies on nutrition and academic achievement abroad are carried out on the basis of nutrition programs given in schools. The common conclusion of the studies conducted to provide evidence that integrating food/nutrition education into the 4th-grade curriculum can support academic knowledge acquisitions is that science and mathematics knowledge overlaps with nutrition knowledge in a holistic way to improve academic knowledge and that nutrition knowledge can also be developed simultaneously among 4th-grade students using science and mathematics curriculum (Kolasa et al., 2018).

There is no special lesson for nutrition in the primary school curriculum in Turkey. Life science lessons include texts for regular and balanced nutrition. In addition, the contents of nutrients and balanced nutrition are briefly emphasized in a unit of the primary school science curriculum. A compulsory or optional nutrition lesson can be included in the primary school curriculum at this point. The content of this lesson can be determined by including families after the needs of students are identified or nutrition workshops can be organized. Lessons can be practically conducted with the participation of families and students in this workshop.

The use of technology in school and elsewhere is another variable with a high impact on science achievement scores. Low scores obtained from the technology use scale (computer, tablet, etc.) in the TIMSS student survey mean that technology is used more frequently. Therefore, students with higher science achievement stated that they use technology less frequently in school but more frequently outside the school for homework purposes. Students' access to technology at school and access to technology in different places other than school and home may differ in terms of duration. Longer time can be spent online for homework, etc. outside school. In addition, it can be interpreted based on the results that students use technology efficiently for homework purposes outside school. 33\% of students are allowed to use computers in science lessons according to the results of TIMSS 2015 (Martin, 
Mullis, Foy et al., 2016). It is known that the use of the Internet during school is limited except for informatics lessons. Therefore, students can turn to technology sources outside the school for their homework. The 8th-grade students who participated in the TIMSS application were asked what the Internet was used for outside the school. The majority of students $(75 \%)$ stated that they mostly use the Internet outside the school to prepare project homework with their friends (Martin, Mullis, Foy et al., 2016). Students can benefit from technology for homework and research purposes if they are given opportunities at school, as a result.

Work in this direction has accelerated in recent years. It is now frequently observed that programs containing many interesting visuals and narratives are used personally by teachers in lessons and that students interactively participate in these programs with the integration of technology into educational environments. It can be easily predicted that the use of computers under the supervision of teachers in schools will positively affect students' achievement considering the nature of the science lesson. It is seen that the issue of ensuring the integration of technology into education and teaching is emphasized within the framework of Turkey's 2023 Education Vision. Turkey shows a successful example of the integration of technology into education in the interaction of student-teacher-parent-school resources with each other in the current pandemic period. Many teachers and students have been struggling with technology in the distance education process. Perhaps the greatest gain when the process is over is the discovery that technology is a useful and inevitable element for education.

\section{Recommendations}

Student and classroom-level variables of this research in relation to student achievement are limited to the items in the student questionnaire and teacher questionnaire in the TIMSS 2015 study and measuring the characteristics at this level. It is also a causal comparison study. The result variable is science achievement scores as measured in the TIMSS application. The sample consists of only a certain number of students and teacher groups who participated in TIMSS 2015. The preference of the experimental method will allow for more detailed discussions about the results in future research. In addition, studies can be conducted with different variables and different groups. The cross-level interactions of the intersection and slope model and the relationships of the variables at different levels with each other can be examined in HLM.

The results of the research on the use of technology showed that the use of technology in other places outside the school negatively affects the science achievement scores of the students while the use of technology in school positively affects the science performance of the students. It may be suggested in light of these results to organize training on the conscious use of technology for students, parents, and teachers, especially primary school age students, regarding their use of technology at home and elsewhere, by the Ministry of National Education and similar organizations interested in education. Practical activities aiming to use the Internet in a beneficial way without damaging the social and academic development of students can be carried out. These activities can be started especially by following the daily usage periods of young primary school students such as tablets, computers, phones, etc. by classroom teachers. Afterward, it should be determined what kind of contents are preferred. The process can continue with useful content on academic and personal development and guidance on channeling technology in the right direction. Activities to be carried out on this subject should be managed by classroom teachers.

Absenteeism was the variable that had the highest effect on science achievement scores at the student level according to the results of the study. Absenteeism negatively affects science achievement scores. In addition, Turkish students are absent more frequently compared to students from other participating countries according to PISA and TIMSS 2015 data. An absenteeism research project can be proposed to be carried out especially in schools on habitual absenteeism (chronic absenteeism), in line with these results. The absenteeism researcher of each school can be appointed by the relevant District Directorate of National Education from among the teachers working in the school within the scope of the project. Teachers who will be assigned as researchers should receive seminars on absenteeism, where the results of the latest academic studies in the literature are also discussed. These teachers 
submit reports to the District Directorates at periods to be determined in the following process. The content of the report may be absent students on a school basis, reasons for absenteeism, interviews, etc. In addition, the researcher also detects and observes students and schools that do not have problems in attendance. The results of this observation can be used for an approach to increase attendance in schools with absenteeism.

Another result of the study is related to nutrition. Coming to school without breakfast negatively and significantly affected science scores. A compulsory or optional nutrition lesson can be included in the primary school curriculum in light of these results. The content of this lesson should be determined after identifying the needs of students. Families can also be included in the nutrition lesson. An elective lesson can be performed by adding a lesson hour to the school exit. Or nutrition workshops can be organized. Lessons can be practically conducted with the participation of families and students in this workshop. Nutrition lesson can be improved with activities such as nutrition problems, relationship between health and nutrition relationship, academic achievement and nutrition, regular and balanced nutrition as well as good examples from daily life.

Recommendations on nutrition can also be improved on students' nutritional breaks. As a matter of fact, students eat what they have brought in their lunch-box during these breaks. How these breaks are spent, how long they last, what students consume, and how nutrition lists are prepared, if any, should be investigated. Accordingly, food engineers can be assigned within the District Directorates of National Education. A school-based supervisor can be designated, and interview days with the food engineer can be arranged periodically. Useful dialogs on students' eating habits should be established in these interviews.

The results of the study at the classroom level show that the variable with the greatest effect on the mean science achievement of the schools is giving feedback on the science homework given. In addition, discussing homework in class has a negative significant effect on achievement. The science achievement scores of the schools where the students who frequently discuss science homework in the classroom were found to be lower compared to the science achievement scores of the schools where the homework is not discussed much according to the results. Classroom level results highlighted teachers' attitudes towards students regarding homework. It can be said that homework also has a psychological structure that affects the academic performance of primary school students when the attitude is considered as an affective factor. The sensitivity of the subject of homework emerges considering these results. Accordingly, the use of homework in the teaching process and the studies examining the attitudes of teachers during this process may contribute to the process. Field studies can be carried out by the relevant institutions on how teachers manage the homework process. Teachers should be provided with training, and their development should be supported according to the results.

One of the problems experienced by the parents of the families who have primary school students in Turkey and the parents of the students who will start the first grade is homework, and parents may have prejudices in this regard. Therefore, this bias can grow and spread to other years of primary school, and this may negatively affect the student's perception of the homework if this bias, which is carried to school with the family at the beginning of the year, is unbreakable. Educators and especially primary school teachers have great duties in this regard. Homework to be given in first grade should be considered meticulously and in accordance with the developmental processes, psychologies, and needs of the students. Homework should not be torture for the child and the family and should be given in line with its purpose. Therefore, studies to be carried out with parents are also important. Accordingly, it may be suggested to create interactive homework portals in schools. Children's interest in digital media may be a good opportunity in this regard. Thus, the reactions of families to homework can also be evaluated instantly. Teachers can comfort families with constructive feedback on homework as an audience and a participant in this process.

\section{REFERENCES}


Acar, M. (2013). Öğrenci başarılarının belirlenmesi sınavında Türkçe dersi başarısının öğrenci ve okul özellikleri ile ilişkisinin hiyerarşik lineer model ile analizi (Doktora tezi). Ankara Üniversitesi Eğitim Bilimleri Enstitüsü, Ankara.

Ackerman, P. L. (2013). Engagement and opportunity to learn. In J. Hattie, \& E. M. Anderman (Eds.), The international guide to student achievement (pp. 39-41). New York: Taylor \& Francis.

Akey, T., M. (2006). School context, student attitudes and behavior, and academic achievement: An exploratory analysis. New York: MDRC. Retrieved from https://files.eric.ed.gov/fulltext/ED489760.pdf

Akkuş, M. (2014). PISA, TIMSS ve PIRLS sonuçlarının değerlendirilmesi (Yüksek lisans tezi). İstanbul Aydın Üniversitesi, Sosyal Bilimler Enstitüsü, İstanbul.

Aktaş, I. (2011). TIMSS 2007 verilerine göre ögrenci fen başarısı ile ögretmenlerinin özellikleri arasındaki ilişkinin incelenmesi (Yüksek lisans tezi). Hacettepe Üniversitesi, Ankara.

Akyüz-Aru, S., \& Kale, M. (2019). Effects of school-related factors and early learning experiences on mathematics achievement: A multilevel analysis to analyze the TIMSS data. Journal of Education and Training Studies, 7(4), 259-272. doi: 10.11114/jets.v7i4.3949

Akyüz, G. (2006). Türkiye ve Avrupa Birliği ülkelerinde öğretmen ve sınıf niteliklerinin matematik başarısına etkisinin incelenmesi. Illkögretim Online, 5(2), 75-86. http://ilkogretim-online.org//?mno=121113 adresinden erişilmiştir.

Akyüz, G., ve Berberoğlu, G. (2010). Teacher and classroom characteristics and their relations to mathematics achievement of the students in the TIMSS. New Horizons in Education, 58(1),77-95. Retrieved from https://www.researchgate.net/publication/293232168_Teacher_and_classroom_characteristics_and_the ir_relations_to_mathematics_achievement_of_the_students_in_the_TIMSS

Alexander, V., \& Hicks, R. E. (2015). Does class attendance predict academic performance in first year psychology tutorials? International Journal of Psychological Studies, 8(1), 28-32. doi: 10.5539/ijps.v8n1p28

Asigbee, F. M., Whitney, S. D., \& Peterson, C. E. (2018). The link between nutrition and physical activity in increasing academic achievement. Journal of School Health, 88(6), 407-415. doi: 10.1111/josh.12625

Atar, H. Y. (2014). Öğretmen niteliklerinin TIMSS 2011 fen başarısına çok düzeyli etkileri. Ĕgitim ve Bilim Dergisi, 39(172), 121-137. http://egitimvebilim.ted.org.tr/index.php/EB/article/view/2894/620 adresinden erişilmiştir.

Atar, H. Y., ve Atar, B. (2012). Türk eğitim reformunun öğrencilerin TIMSS 2007 fen başarılarına etkisinin incelenmesi. Kuram ve Uygulamada Eğitim Bilimleri, 12(4), 2621-2636.

Aydın, M. (2015). Öğrenci ve okul kaynaklı faktörlerin TIMSS matematik başarısına etkisi (Doktora tezi). Necmettin Erbakan Üniversitesi, Eğitim Bilimleri Enstitüsü, Konya.

Ayvaz, A. (2010). 4. sınıf matematik dersi bölme işlemi alt ögrenme alanının edebi ürünlerle işlenmesinin ögrenci başarı ve tutumuna etkisi (Yüksek lisans tezi). Sakarya Üniversitesi, Sosyal Bilimler Enstitüsü, Sakarya.

Bénabou, R., Kramarz, F., \& Prost, C. (2009). The French zones d'éducation prioritaire: Much ado about nothing? Economics of Education Review, 28(3), 345-356.

Bilican-Demir, S. (2014). Değerlendirme. S. Tekindal (Ed.), Ĕ̆itimde ölçme ve değerlendirme içinde (ss. 225257). Ankara: Pegem Akademi.

Blömeke, S., Olsen, R. V., \& Suhl, U. (2016). Teacher quality, insturactional quality and student outcomes, relationshps accross countries, cohorts and time. In T. Nilsen \& J. E. Gustafsson (Eds.), Relation of student achievement to the quality of their teachers and instructional quality (pp. 21-51). Switzerland: IEA Publishing.

Blömeke, S., Suhl, U., \& Kaiser, G. (2011). Teacher education effectiveness: Quality and equity of future primary teachers' mathematics and mathematics pedagogical content knowledge. Journal of Teacher Education, 62, 154-171.

Büyüköztürk, Ş., Çakan, M., Tan, Ş. ve Atar, H. Y. (2014). TIMSS 2011 Ulusal Matematik ve Fen Raporu. Ankara: İşsur Matbaacılık.

Büyüköztürk, Ş., Kılıç Çakmak, E., Akgün, Ö. E., Karadeniz, Ş., ve Demirel, F. (2011). Bilimsel araştırma yöntemleri. Ankara: Pegem Akademi.

Cattan, S., Kamhöfer, D. A., Karlsson, M., \& Nilsson, T. (2017). The short-and long-term effects of student absence: Evidence from Sweden (IZA DP No. 10995). Retrieved from http://ftp.iza.org/dp10995.pdf

Clinton, J. (2013). Physical activity. In: J. Hattie, and E. M. Anderman (Eds.), The international guide to student achievement (pp. 33-35). New York, NY: Taylor \& Francis.

Clinton, J., Rensford, A., \& Willing, E. (2007). Literature review of the relationship between physical activity, nutrition and academic achievement. New Zeland: Auckland Centre for Health Services, Research and Policy, University of Auckland.

ISSN: 1309 - 6575 Eğitimde ve Psikolojide Ölçme ve Değerlendirme Dergisi 
Creemers, B. P., \& Kyriakides, L. (2006). Critical analysis of the current approaches to modelling educational effectiveness: The importance of establishing a dynamic model. School Effectiveness and School Improvement, 17(3), 347-366.

Çavdar, D. (2015). TIMSS 2011 matematik başarısının öğrenci ve öğretmen özellikleri ile ilişkisi (Yüksek lisans tezi). Gazi Üniversitesi, Eğitim Bilimleri Enstitüsü, Ankara.

Çelebi, N., Güner, H., Taşçı-Kaya, G. ve Korumaz, M. (2014). Neoliberal eğitim politikaları ve eğitimde firsat eşitliği bağlamında uluslararası sınavların (PISA, TIMSS ve PIRLS) analizi. Tarih Kültür ve Sanat Araştırmaları Dergisi, 3(3), 33-75. doi: 10.7596/taksad.v3i3.329

Çokluk, Ö., Şekercioğlu, G., ve Büyüköztürk, Ş. (2018). Sosyal bilimler için çok değişkenli istatistik SPSS ve LISREL uygulamaları. Ankara: Pegem Akademi.

Daniels, D. H., \& Perry, K. E. (2003). "Learner-centered" according to children. Theory into Practice, 42(2), 102-109. doi: 10.1207/s15430421tip4202_3

Deci, E., \& Ryan, R. (1985). Intrinsic motivation and self-determination in human behavior. New York: Plenum.

Doğan, U. (2014). Validity and reliability of student engagement scale. Bartın Üniversitesi Eğitim Fakültesi Dergisi, 3(2), 390-403. Retrieved from https://dergipark.org.tr/en/download/article-file/43660

Dwyer, T., Sallis, J. F., Blizzard, L., Lazarus, R., \& Dean, K. (2001). Relation of academic performance to physical activity and fitness in children. Pediatric Exercise Science, 13, 225-237.

Ekinci-Vural, D. (2012). Okul öncesi eğitimin ilköğretime etkisinin aile katılımı ve çeşitli değişkenler açısından incelenmesi (Doktora tezi). Dokuz Eylül Üniversitesi Eğitim Bilimleri Enstitüsü, İzmir.

Erşan, Ö. (2016). TIMSS 2011 8. Sinıf öğrencilerinin matematik başarılarını etkileyen faktörlerin yapısal eşitlik modeliyle incelemesi (Yüksek lisans tezi). Hacettepe Üniversitesi, Ankara.

Ferguson, C. J. (2009). An effect size primer: A guide for clinicians and researchers. Professional Psychology: Research and Practice, 40(5), 532-538. doi: 10.1037/a0015808

Fraenkel, J. R., Wallen, N. E., \& Hyun, H. H. (2012). How to design and evaluate research in education. New York: McGraw- Hill.

Fullarton, S., Lokan, J., Lamb, S. \& Ainley, J. (2003). Lessons from the third international mathematics and science study (TIMSS Australia Monograph No. 4). Melbourne: Australian Council for Educational Research.

Garcia, E., \& Weiss, E. (2018). Student absenteeism-Who misses school and how missingschool matters for performance (Economic Policy Institute Report). Retrieved from https://files.eric.ed.gov/fulltext/ED593361.pdf

Garson, D. (2008). Data imputation for missing values. Retrieved from https://faculty.chass.ncsu.edu/garson/PA765/index.htm

Glass, G. V., McGaw, B., \& Smith, M. L. (1981). Meta-analysis in social research. London: Sage.

Güngör, H. (2014). Illkokul 4. sınıf matematik dersi "kesirler" konusunun öğretiminde yardımcı kitap kullanımının ögrrenci başarısı üzerindeki etkisi. (Yüksek lisans tezi). Yüzüncü Yıl Üniversitesi, Eğitim Bilimleri Enstitüsü, Van.

Hattie, J. (2009). Visible learning: A synthesis of over 800 meta-analyses relating to achievement. Newyork: Routledge.

Heck, R. H., \& Thomas, S. L. (2009). An introduction to multlievel modeling techniques. New York: Routledge.

Hiebert, J., Carpenter, C. P., Fennema, E., Fuson, K., Wearne, D., Murray, H., Olivier, A., \& Human, P. (1997). Making sense: Teaching and learning mathematics with understanding. Portsmouth, NH: Heinemann.

Hooper, M., Mullis, I. V. S., \& Martin, O. M. (2013). TIMSS 2015 Context questionnaire framework. In I. V. S. Mullis, \& M. O. Martin (Eds.), TIMSS 2015 assessment frameworks (pp. 61-80). United States Boston College: TIMSS and PIRLS International Study Center.

Hox, J. J. (1995). Applied multilevel analysis. Amsterdam, Netherlands: TT- publicities.

Hox, J. J. (2002). Applied multilevel analysis. Mahwah, NJ: Erlbaum.

Hox, J. J. (2010). Multilevel analysis: Techniques and applications. New York: Taylor \& Francis.

İsmail, N. A., \& Awang, H. (2008). Assessing the effects of students' characteristics and attitudes on mathematics performance. Problems of Education in $21^{\text {st }}$ Century, 9, 34-41. Retrieved from https://www.researchgate.net/profile/Noor-Ismail-

18/publication/268226049_Effects_of_Teachers_and_Schools_on_Mathematics_AchievementsProble ms_of_Education_in_the_21st_Century_Recent_Issues_in_Education/links/5466d1b10cf2397f7829e6 37/Effects-of-Teachers-and-Schools-on-Mathematics-AchievementsProblems-of-Education-in-the21st-Century-Recent-Issues-in-Education.pdf

İpekçioğlu-Önal, S. (2015). TIMSS 2011 cross country comparisons: relationship between student-and teacher -level factors and $8^{\text {th }}$ grade students' achievement and attitude toward science (Doctoral thesis). Middle East Technical University, Secondary Science and Mathematics Education Department, Ankara. 
Karip, E. (2017). Türkiye’nin TIMSS 2015 performansı üzerine değerlendirme ve öneriler. https://tedmem.org/download/turkiyenin-timss-2015-performansi-uzerine-degerlendirme oneriler? $w p d m d l=2515$ adresinden erişilmiştir.

Kaya, S. (2008). The effects of student-level and classroom-level factors on elementary students' science achievement in five countries (Doctoral dissertation). Florida State University, Florida.

Keeley, T. J. H., \& Fox, K. R. (2009). The impact of physical activity and fitness on academic achievement and cognitive performance in children. International Review of Sport and Exercise Psychology, 2(2), 198214. doi: 10.1080/17509840903233822

Khalid, N. (2017). Effects of absenteeism on students' performance. International Journal of Scientific and Research Publications,7(9), 151-168. Retrieved from http://www.ijsrp.org/research-paper0917.php?rp=P696781

Kılıç-Özün, S. (2010). Hayat bilgisi öğretiminde kavram karikatürü yaklaşımının öğrenci başarısı ve tutumuna etkisi (Yüksek lisans tezi). Zonguldak Karaelmas Üniversitesi, Sosyal Bilimler Enstitüsü, Zonguldak.

Klem, A. M., \& Connell, J. P. (2004). Relationships matter: Linking teacher support to student engagement and achievement. Journal of School Health, 74(7), 262-273. Retrieved from https://scholar.google.com.tr/scholar?q=Klem,+A.+M.,+\%26+Connell,+J.+P.+(2004).+Relationships+ matter:\&hl=tr\&as_sdt=0\&as_vis=1\&oi=scholart

Kolasa, K. M., Díaz, S. R., \& Duffrin, M. W. (2018). Exploring the associations among nutrition, science, and mathematics knowledge for an integrative, food-based curriculum. Journal of School Health, 88(1), 1522. doi: 10.1111 josh. 12576

Korkmaz, F. (2012). Contribution of some factors to eight grades students' science achievement in Turkey: TIMSS 2007 (Doctoral dissertation). Middle East Technical University, Ankara.

Kunuk, M. (2015). Okul öncesi ĕgitimin ilkokul öğrencilerinin akademik başarllarına etkisi (Üsküdar örneği) (Yüksek lisans Tezi). İstanbul Aydın Üniversitesi, Sosyal Bilimler Enstitüsü, İstanbul.

Kyriakides, L. (2006). Using international comparative studies to develop the theoretical framework of educational effectiveness research: A secondary analysis of TIMSS 1999 data. Educational Research and Evaluation, 12(6), 513-534.

Lamb, S., \& Fullarton, S. (2002). Classroom and school factors affecting mathematics achievement: A comparative study of Australia and the United States using TIMSS. Australian Journal of Education, 46(2), 154-171. doi: 10.1177/000494410204600205

LaRoche, S., \& Foy, P. (2016). Sample implementation in TIMSS 2015. In M. O. Martin, I. V. S. Mullis, \& M. Hooper (Eds.), Methods and procedures in TIMSS 2015 (pp. 5.1- 5.170). Retrieved from https://timssandpirls.bc.edu/publications/timss/2015-methods/chapter-5.html

Lee, J. W., \& Barro, R. J. (2001). Schooling quality in a cross-section of countries. Economica, New Series, 68(272), 465-488.

Lee, V. E., \& Zuze, T. L. (2011). School resources and academic performance in Sub-Sharan Africa. Comparative Education Review, 55(3), 369-397. Retrieved from https://www.jstor.org/stable/10.1086/660157?seq=1

Lieberman, D. A., Bates, C. H., \& So, J. (2009) Young children's learning with digital media. Computers in the Schools, 26(4), 271-283. doi: 10.1080/07380560903360194

Liouaeddine, M., Bijou, M., \& Naji, F. (2017). The main determinants of Moroccan students' outcomes. American Journal of Educational Research,5(4), 367-383. doi: 10.12691/education-5-4-5

Martin, M. O., Mullis, I. V. S., \& Foy, P. (2013). TIMSS 2015 assessment design. In I. V. S. Mullis \& M. O. Martin (Eds.), TIMSS 2015 assessment frameworks (pp. 85-96). Chestnut Hill, MA: TIMSS \& PIRLS International Study Center, Boston College.

Martin, M. O., Mullis, I. V. S., Foy, P., \& Hooper, M. (2016). TIMSS 2015 international results in science. Retrieved from http://timssandpirls.bc.edu/timss2015/international-results/

Martin, M. O., Mullis, I. V. S., Gonzalez, E. J., Gregory, K. D., Smith, T. A., Chrostowski, S. J., Garden, R. A. \& O’Connor, K. M. (2000). TIMSS 1999 international science report. Retrieved from https://timssandpirls.bc.edu/timss1999i/pdffT99i_Sci_All.pdf

Martin, M. O., Mullis, İ. V. S., Hooper, M, Yin, L., Foy, P., \& Palazzo, L. (2016). Creating and interpreting the TIMSS 2015 context questionnaire scales. In M. O. Martin, I. V. S. Mullis \& M. Hooper (Eds.), Methods and procedures in TIMSS 2015 (pp. 15.1-15.312). Retrieved from https://timss.bc.edu/publications/timss/2015-methods/chapter-15.html

Marzano, R. J. (2003). What works in school: Translating research into action (1st ed.). Alexandria, VA: Association for Supervision \& Curriculum Development.

Mertler, C. A., \& Vannatta, R. A. (2005). Advanced and multivariate statistical methods: Practical application and interpretation (3rd ed.). Glendale, CA: Pyrcz Publishing.

ISSN: 1309 - 6575 Eğitimde ve Psikolojide Ölçme ve Değerlendirme Dergisi

Journal of Measurement and Evaluation in Education and Psychology 
Mohammadpour, E., \& Abdul Ghafar, M. N. (2014). Mathematics achievement as a function of within-andbetween school differences. Scandinavian Journal of Educational Research, 58(2), 189-221. doi: 10.1080/00313831.2012.725097

Mohammadpour, E., Shekarchizadeh, A., \& Kalantarrashidi, S. A. (2015). Multilevel modeling of science achievement in the TIMSS participating countries. The Journal of Educational Research, 108(6)1-16. doi: 10.1080/00220671.2014.917254

Mullis, I. V. S., Martin, M. O., Gonzalez, E. J., \& Kennedy, A. M. (2003). PIRLS 2001 international report: IEA's study of reading literacy achievement in primary school in 35 countries. Chestnut Hill, M.A.: International Study Center, Boston College.

Nilsen, T., Gustafsson, J. E. \& Blömöke, S. (2016). Conceptual framework and methodology of the report. In T. Nilsen \& J. E. Gustafsson (Eds.), Teacher quality, insturactional quality and student outcomes, relationshps accross countries, cohorts and time (pp. 1-21). Switzerland: IEA Publishing. Retrieved from https://link.springer.com/chapter/10.1007/978-3-319-41252-8_1

Organisation for Economic Co-operation and Development. (2013). Education Policy Outlook: Turkey. Retrieved from http://www.oecd.org/edu/EDUCATION\%20POLICY\%20OUTLOOK\%20TURKEY_EN.pdf.

Organisation for Economic Co-operation and Development. (2015). Education at a Glance. Retrieved from https://www.oecd-ilibrary.org/education/education-at-a-glance-2015_eag-2015-en

Olson, J. F., Martin, M. O. \& Mullis, I. V. S. (2008). TIMSS 2007 technical report. United States: International Study Center, Boston College.

Ozborne, J. W. (2002). Notes on the use of data transformations. Practical Assessment Research anad Evaluation, 8.

Özdemir, S. (2013). Türk eğitim sistemi ve okul yönetimi. S. Özdemir (Ed.), Türk eğitim sisteminin yapısl, eğilimleri ve sorunları içinde (ss. 7- 52). Ankara: Pegem Akademi.

Özden, M. (2007). Problems with science and technology education in Turkey. Eurasia Journal of Mathematics, Science \& Technology Education, 3(2), 157-161. Retrieved from https://www.ejmste.com/download/problems-with-science-andtechnology-education-in-turkey4061.pdf

Özgen, C. (2009). The connection between school and student characteristics with mathematics achievement in Turkey (Doctoral dissertation). Middle East Technical University, Varsa Enstitü Bilgisi, Ankara.

Raudenbush, S. V., \& Bryk, A. S. (2002). Hierarchical linear models: Applications and data analysis methods. London: Sage.

Reddy, V. (2005). Cross-national achievement studies: learning from South Africa's participation in the trends in international mathematics and science study (TIMSS). A Journal of Comparative and International Education, 35(1), 63-77. doi: 10.1080/03057920500033571

Ryan, R. M., \& Deci, E. L. (2000). Self-determination theory and the facilitation of intrinsic motivation, social development, and well-being. American Psychologist, 55(1), 68-78. Retrieved from https://selfdeterminationtheory.org/SDT/documents/2000_RyanDeci_SDT.pdf

Ryoo, H. (2001). Multilevel influences on student achievement: An international comparative study (Doctoral dissertation). Available from ProQuest Dissertations and Theses database.

Sarı, M. H., Arıkan, S. ve Yıldızlı, H. (2017). 8. Sınıf matematik akademik başarısını yordayan faktörler-TIMSS 2015. Eğitimde ve Psikolojide Ölçme ve Değerlendirme Dergisi, 8(3), 246-265. doi: 10.21031/epod.303689

Savaş, E., Taş, S. ve Duru, A. (2016). Factors affecting students' achievement in mathematics. Inonu University Journal of the Faculty of Education, 11(1), 113-132. Retrieved from https://dergipark.org.tr/tr/download/article-file/92276

Selçuk, E. (2015). Müzik dersinde zihin haritalama tekniği kullanımının ögrenci başarısı ve tutumlarına etkisi (Yüksek lisans tezi). Marmara Üniversitesi Eğitim Bilimleri Enstitüsü, İstanbul. https://tez.yok.gov.tr/UlusalTezMerkezi/tezDetay.jsp?id=oBF44VZN7pDvnhafMH48dw\&no=151CbO tziZRIPV_Nj4M4RQ adresinden erişilmiştir.

Sevgi, S. (2009). The connection between school and student characteristics with mathematics achievement in Turkey (A thesis submitted to the graduate). Middle East Technical Universty, Secondary Science and Mathematics Education Department, Ankara.

Sezer, E. (2016). Öğretmenlerin kişisel ve mesleki niteliklerinin 4 ve 8. Sinıf öğrencilerinin TIMSS 2011 matematik başarısına etkisinin incelenmesi (Yüksek lisans tezi). Gazi Üniversitesi, Eğitim Bilimleri Enstitüsü, Ankara.

Shaw, S. R., Gomes, P., Polotskaia, A., \& Jankowska, A. M. (2015). The relationship between student health and academic performance: Implications for school psychologists. School Psychology International, 36(2), 115-134. doi: 10.1177/0143034314565425 
Sirin, S. R. (2005). Socioeconomic status and academic achievement: A meta- analytic review of research. Review of Educatilnal Research, 75(3), 417-453. doi: 10.3102/00346543075003417

Stemler, S. E. (2001). Examining school effectiveness at the fourth grade: A hierarchical analysis of the third international mathematics and science study (TIMSS). (Submitted in partial fulfillment of the requirements for the degree of Doctor of Philosophy). Wesleyan University, Department of Psychology, United States.

Tabachnick, B. G., \& Fidell, L. S. (2001). Using multivariate statistics. Boston: Ally and Bacon.

Taştekinoğlu, E. (2014). 4. sınıf matematik sorularının bilişsel alan kapsamında incelenmesi; TIMSS sınav sorularıyla karşılaşstırmalı bir analiz (Yüksek lisans tezi). İstanbul Aydın Üniversitesi, Sosyal Bilimler Enstitüsü, İstanbul.

Toraman, Ç., Akay, E., Özdemir, H. F. ve Karadağ, E. (2011). Çok düzeyli regresyon modelleri, HLM uygulamalart. Ankara: Nobel.

Trautwein, U. (2007). The homework achievement relation reconsidered: Differentiating homework time, homework frequency, and homework effort. Learning and Instruction, 17(3), 372-388. doi: 10.1016/j.learninstruc.2007.02.009

Uzun, S., Bütüner, S. Ö. ve Yiğit, N. (2010). A comparison of the results of TIMSS 1999-2007: The most successful five countries-Turkey sample. Elementary Education Online, 9(3), 1174-1188. Retrieved from https://dergipark.org.tr/tr/download/article-file/90742

Van de Valle, J. A., Karp, K. S., \& Bay-Williams, J. M. (2010). Elementary and middle school mathematics teaching developmentally. USA, Pearson.

van den Broeck, A., Opdenakker, M. C., \& Van Damme, J. (2005). The effects of student characteristics on mathematics achievement in Flemish TIMSS 1999 data. Educational Research and Evaluation, 11(2), 107-121. doi: 10.1080/13803610500110745

Webster, B. J., \& Fisher, D. L. (2000). Accounting for variation in science and mathematics achievement: A multilevel alaysis of Australian data third international mathematics and science study. School Effectivenes and School Improvement, 11(3), 339-360.

Wenglinsky, H. (2000). How teaching matters: Bringing the classroom back into discussions of teacher quality. Princeton, NJ: Educational Testing Service.

Won, S. J., \& Han, S. (2010). Out-of-school activities and achievement among middle school students in the U.S. and South Korea. Journal of Advanced Academics, 21(4), 628-661. doi: $10.1177 / 1932202 \times 1002100404$

World Bank (2011). Improving the quality and equity of basic education in turkey challenges and options. The World Bank: Washington D.C.

Wößmann, L. (2003). Schooling resources, educational institutions and pupil performance: international evidence. Oxford Bull Economics Statistics, 65(2), 117-170. doi: 10.1111/1468-0084.00045

Yaman, İ. (2004). Modeling the realationship between the science teacher characteristics and eight grade Turkish student science achievement in TIMSS- $R$ (Yüksek lisans tezi). Orta Doğu Teknik Üniversitesi, Fen Bilimleri Enstitüsü, Ankara.

Yatağan, M. (2014). Fen ve teknoloji dersi öğretim programının ögrrenci ve ögretmen özelliklerine göre değerlendirilmesi: TIMSS 2007 ve 2011 verileri ile bir durum analizi (Doktora tezi). Gazi Üniversitesi, Eğitim Bilimleri Enstitüsü, Ankara.

Y1lmaz, H. B., ve Aztekin, S. (2012, Haziran). Türkiye 'deki düzey istatistiki bölge birimlerine göre 15 yaş grubu ögrencilerinin akademik başarılarını etkileyen bazı faktörlerin incelenmesi. X. Ulusal Fen Bilimleri ve Matematik Eğitimi Kongresinde sunulan sözlü bildiri, Niğde, Türkiye.

Yücel, C., ve Karadağ, E. (2016). TIMSS 2015 Türkiye; Patinajdaki eğitim. doi: 10.13140/RG.2.2.20445.20964/1

Zhu, Y., \& Leung, F. K. S. (2012). Homework and mathematics achievement in Hong Kong: Evidence from the TIMSS 2003. International Journal of Science and Mathematics Education, 10(4), 907-92. doi: $10.1007 / \mathrm{s} 10763-011-9302-3$ 


\title{
Öğrenci Niteliklerinin ve Sınıf İçi Değişkenlerin Fen Başarısına Çok Düzeyli Etkileri *
}

\author{
Sidıka AKYÜZ ARU **
}

Mustafa KALE ***

\begin{abstract}
Öz
$\mathrm{Bu}$ araştırmanın amacı, öğrenci niteliklerinin ve okulda öğretim sürecine ilişkin, bazı sınıf içi değişkenlerin Türkiye'deki 4. sınıf öğrencilerin TIMSS fen başarısına etkilerini belirlemektir. Nedensel karşılaş̧ırma deseniyle yürütülen bu çalışmada ayrıca okullar arasında ortaya çıkan başarı farklılıklarını öğrenci ve sınıf düzeyinde açıklamaya en çok katkı sağlayan değişkenlerin belirlenmesi amaçlanmıştır. Araştırmanın örneklemini, 6378 öğrenci ve bu öğrencilerin sınıf öğretmenleri oluşturmaktadır. Bu gruba ait veri, İki Düzeyli Hiyerarşik Lineer Model (HLM) kullanılarak analiz edilmiştir. HLM analizi sonucunda, öğrenci düzeyinde devamsızlık yapmama, kahvaltı yapmama, okulda teknoloji kullanımı, okul ve ev dışında teknoloji kullanımının fen başarı puanları üzerindeki etkileri istatistiksel olarak anlamlı bulunmuştur. Sınıf düzeyinde ise, okulun imkan ve kaynaklarının yetersizliğine ilişkin öğretmenlerin algıları, ödevlere geri bildirim verilmesi, sınıfta ödevlerin tartışılması ve öğrencilerin sınıfta verdiği cevapları açıklamasının fen başarısına etkileri manidardır. Bu sonuçlar, ilkokul öğrencilerinin akademik performanslarının geliştirilmesinde öğrencilerle ilişkili olup öğretim sürecini olumlu veya olumsuz yönde etkileyebilecek bir takım psikolojik ve fiziksel özelliklerin önemini ortaya koymaktadır.
\end{abstract}

Anahtar Kelimeler: Sınıf içi değişkenler, öğrenci nitelikleri, fen başarısı, TIMSS, HLM.

\section{GíRiş}

21. yüzyılda okulu amaçları doğrultusunda yaşatmak, tarafların mutluluğunu ve doyumunu sağlamak, başarılması çok zor gibi görünen çok bilinmeyenli bir denklem gibi karşımızda durmaktadır (Özdemir, 2013). Dolayısıyla, okulun değişen işlevlerine karşın eğitim sistemlerinin bu işlevleri karşılayabilecek düzeyde yeniden ele alınması ihtiyacı ortaya çıkmaktadır. Bu doğrultuda, eğitim sistemini meydana getiren bütün unsurlar, mevcut durumun betimlenmesi, eksikliklerin ve ihtiyaçların ortaya konması ve ileriki dönemlerde gerçekleştirilecek faaliyetlerin belirlenmesi amacıyla değerlendirme sürecine tabi tutulmaktadır (Bilican-Demir, 2014).

Bu noktada, yapılacak olan değerlendirme faaliyetinin vereceği bilgiler önemlidir. Reddy (2005), ülkelerin eğitim sistemlerini değerlendirmenin en verimli yolunun sistemin unsurlarından biri olan çıktıların yani öğrenci başarılarının değerlendirilmesi olduğunu belirtirken bu konuda izlenebilecek en gerçekçi yaklaşımın uluslararası karşılaştırmalar olacağını vurgulamaktadır.

Bu bağlamda Türkiye, 1999 yılından bu yana uluslararası geniş ölçekli test uygulamalarından olan Uluslararası Matematik ve Fen Eğilimleri Araştırması'na (Trends in Mathematics and Science Study, TIMSS) katılmaktadır. TIMSS, Türk eğitim sistemini, uluslararası düzeyde eğitim sistemleri ile karşılaştırma yaparak, elde edilen bilimsel veriler ışı̆̆ında gerekli değişikliklerin yapılmasına fırsat vermektedir. Ayrıca TIMSS, uygulamaya katılan öğrencilerin başarı puanları doğrultusunda yeterlik düzeylerine göre sinıflandırılması, öğrencilerin yeteneklerinin belirlenmesi ve bunların değerlendirilmesi adına bir imkân sunmaktadır.

\footnotetext{
* $\mathrm{Bu}$ araştırma "4. Sınıf Öğrencilerinin Fen ve Matematik Başarısına Etki Eden Değişkenlerin İncelenmesi: TIMSS Verilerinin Çok Düzeyli Analizi” adlı doktora tez çalışmasından üretilmiştir.

** Dr., Millî Eğitim Bakanlığı, Ankara-Türkiye, SIDIKAARU@gmail.com, ORCID ID: 0000-0002-5991-2288

*** Doç. Dr., Gazi Üniversitesi, Eğitim Fakültesi, Ankara-Türkiye, mkale@gazi.edu.tr, ORCID ID: 0000-0002-3727-1475
}

Bu makaleye atıfta bulunmak için:

Akyüz-Aru, S., \& Kale, M. (2021). Multilevel effects of student qualifications and in-classroom variables on science achievement. Journal of Measurement and Evaluation in Education and Psychology, 12(2), 71-96. doi: 10.21031/epod.756083 
Bugüne kadar ortaya konan sonuç raporlarında (1999-2015) Türk öğrencilerin yeterlik düzeylerine bakıldığında Fen bilimleri alanında düşük düzeyin altında kalan öğrenci yüzdesinin (\%18), TIMSS ortanca değeri olan \%5'in yaklaşık 3.5 katı olduğu görülmektedir (Karip, 2017). Bu bulgu, bir yıl için 225 bin 4. sınıf öğrencisinin, fen bilimleri alanında düşük düzeyin altında bir performansla yani temel becerilerden yoksun olarak ilkokuldan ortaokula geçtiğini göstermektedir (Karip, 2017). Bir diğer ifadeyle, Türk öğrencilerin hemen hemen yarısının $(n=3250)$ alt ve daha da alt yeterlilik düzeyinde bulunması, öğrendikleri temel bilgileri hayata geçirme, bu bilgileri karşılaştıkları problemlere uyarlama ve hatta hatırlama anlamında sıkıntı yaşadıklarını göstermektedir (Yücel \& Karadağ, 2016). Ne yazık ki bu tip problemler akademik başarıya doğrudan etki etmektedir (Mullis, Martin, Gonzalez, \& Kennedy, 2003). Nitekim, farklı yıllarda TIMSS verileri üzerinde yapılan araştırmaların (Büyüköztürk, Çakan, Tan, \& Atar, 2014; Martin ve diğerleri, 2000; Olson, Martin, \& Mullis, 2008; Özden, 2007; Uzun, Bütüner, \& Yiğit, 2010) bulguları Türk öğrencilerin fen başarısının genel başarı ortalamasından daha düşük olduğunu göstermektedir.

\section{Öğrenci Niteliklerinin ve Sınıf İçi Değişsenlerin Başarıya Etkisi}

Öğrenci nitelikleri ve başarı arasındaki ilişkililerin incelendiği çalışmaları konu alan meta analiz çalışmaları (Hattie, 2009; Marzano, 2003), doğrudan öğrenciye ilişkin faktörlerin akademik başarı üzerinde yüksek bir etkiye sahip olduğunu göstermektedir. Mohammadpour, Shekarchizadeh ve Kalantarrashidi'in (2015), 29 ülkenin 8. sınıf öğrencilerinin TIMSS 2007 fen puanlarına etki eden öğrenci, okul ve ülke özelliklerini incelediği çalışmada, öğrenci başarılarındaki varyansın büyük bir bölümü öğrenci düzeyinde bulunan özeliklerce açıklandığı bulunmuştur.

Literatürde pek çok öğrenci niteliğinin konu edildiği görülmektedir. Kaya (2008), TIMSS 2003, öğrenci başarılarıyla ilişkili olarak öğrenci düzeyinde cinsiyet, özgüven ve ev kaynaklarını ele almıştır. Aydın (2015), öğrenci düzeyindeki verileri, öğrenci duyuşsal özellikleri ve öğrenci karakteristik özellikleri olarak tanımlamıştır. İpekçioğlu-Önal (2015), öğrenci düzeyindeki faktörleri; cinsiyet, evde kullanılan eğitsel kaynaklar, aile katılımı, ödevler, zorbalığa uğrama olarak belirlemiştir. Sarı, Arıkan ve Yıldızlı (2017), öğrenci düzeyinde, duyuşsal özellikler (öz yeterlik, tutum ve öğrenme değeri), evdeki kaynaklar, okula aidiyet, zorbalık ve öğretim etkinliklerini incelemiştir.

Ancak başarıdaki değişkenliği açıklama gücü yüksek olmasına rağmen devamsızlık, beslenme, teknoloji kullanımı gibi öğrenci özelliklerinin araştırmalarda yeterince irdelenmediği farklı çalı̧̧malarda (Asigbee, Whitney, \& Peterson, 2018; Garcia \& Weiss, 2018; İsmail \& Awang, 2008; Khalid, 2017; Kolasa, Díaz, \& Duffrin, 2018; Liouaeddine, Bijou, \&, Naji, 2017) belirtilmektedir.

Klem ve Connell (2004) ve Ackerman (2013) devamsızlı̆ı̆n, öğrencilerin okuldaki etkinliklere katılımının ve derslere düzenli bir şekilde devam etmenin, öğrencilerin motivasyonlarını doğrudan ve olumlu yönde etkileyen bir faktör olduğunu; okuldaki süreçlere devamlı bir şekilde katılım sağlayan öğrencilerin, derslere karşı olumlu tutum geliştirmekte olduğunu ve ödev performanslarının yükseldiğini vurgulamıştır. Bunlara ek olarak zorlu okul şartları, olumsuz iklim ve ağır öğretim programları altında ezilen öğrencilerin, okula gitmeme ve hatta okulu terk etme eğilimi gösterdiği yapılan çalışmalarda (Akey, 2006; Doğan, 2014) vurgulanan bir diğer unsurdur. Benzer şekilde, öğrencilerin akademik başarılarını yakından etkileyen bir diğer faktör beslenmedir. Ekonomik İşbirliği ve Kalkınma Teşkilatı (The Organisation for Economic Co-operation and Development-OECD) raporları en gelişmiş ülkelerde bile pek çok öğrencinin dikkatini derse verebilmek için açlik ve uykusuzlukla mücadele ettiğini ortaya koymaktadır (OECD, 2015). Clinton (2013), beslenme ve fiziksel aktivite olarak avantajlı olan çocukların, bu konuda dezavantajlı olanlara oranla etkili öğrenmeye daha açık olduğunu bulmuştur. Ancak Clinton, Rensford ve Willing (2007), beslenmenin akademik başarıyı çok yüksek seviyelere çıkardığı konusunda literatürde doğrudan bir araştırma sonucu bulunmadığını belirtmektedir. Dolayısıyla beslenme başarıyı etkileyebileceği düşünülen faktörlerden yalnızca birisidir.

Çalışmalarda öğrenci düzeyinde göz ardı edilmiş bir diğer faktör ise, öğrencilerin teknoloji kullanımlarıdır. Teknolojinin gelişmesiyle birlikte, özellikle çocukların, vakitlerinin çoğunu, ekitaplar, tabletler ve akıllı telefonlar gibi yeni dijital medya ile etkileşim halinde geçirmeye başladığı 
bilinmektedir (Lieberman, Bates, \& So, 2009). Günlük yaşantılarının bir bölümü okulda geçen çoğu çocuğun teknolojiden etkilenme biçimi akademik başarısına olumlu veya olumsuz yönde yansıyabilmektedir. Ebeveynler, örneğin telefonlarda ve diğer dijital medya araçlarında kullanılabilen eğitim uygulamalarının doğru yönde kullanıldığı taktirde bunların, erken yaştaki çocukların eğitiminde etkili ve tamamlayıcı olabileceğini düşünse de (Chiong \& Shuler, akt. Hooper, Mullis, \& Martin, 2013) bu konu araştırılmaya değerdir. Dolayısıyla özellikle literatürdeki eksikliği gidermek ve öğrenci başarılarındaki varyansı açıklamadaki etkilerinin görülmesi adına mevcut çalışmanın öğrenci düzeyinde beslenme, devamsızlık ve teknoloji kullanımı yer almıştır.

Hox (1995), eğitim alanında yapılan ölçmede esas olan öğrenci niteliklerinin, öğrencinin öğrenim gördüğ̈̈ okul ve sınıfın özelliklerinden etkilendiğini belirtmektedir. Öğretim ve öğrenme etkinliklerinin pek çoğunun sınıf içerisinde gerçekleşmesi dolayısıyla faydalı bir öğrenmenin sınıf çevresi ve sınıf içi değişkenlerden olan öğretimsel aktivitelerden etkilenmesi kaçınılmazdır (Hooper ve diğerleri, 2013; Nilsen, Gustafsson, \& Blömöke, 2016). Hattie (2009), meta analiz çalışmasında, sınıf içi değişkenlerin (sınıf içi öğretimsel etkileşimler, sınıf içi materyaller ve dersler konusunda okul kaynakları, sınıf içi değerlendirme metotları vb.) öğrenci başarısını anlamlı düzeyde etkilediğini ancak sınıf düzeyinde yeterince çalışılmadığını belirtmektedir.

Türkiye'de bu konuda yapılan araştırmalara bakıldığında, sınıf düzeyinde başarıyla ilişkili olarak, ders araçları, öğrenci ve ebeveyn özellikleri ile ilgili çalışmalar (Aydın, 2015; Çavdar, 2015; Erşan, 2016; Korkmaz, 2012) ile sınıf içi ve dışında kullanılan öğretim yöntem teknikleri ve öğrenme ortamları, ülke öğretmen yetiştirme politikaları ve öğretmen eğitimi, öğretmenlerin edindikleri tecrübe, öğretmen nitelikleri, öğretmen yetiştirmeye yönelik tutumlar, okul yönetiminin yapısı ve liderlik anlayışını inceleyen çalışmaların (Aktaş, 2011; Atar, 2014; Sezer, 2016) olduğu görülmektedir. Ayrıca, TIMSS sonuçlarının ülkeler arasında karşılaştırmalı olarak incelendiği (Akkuş, 2014), uluslararası sınavların eğitim politikaları ve eğitimde firsat eşitliği işle ilişkisine bakıldığ1 (Çelebi, Güner, Taş̧̧ı-Kaya, \& Korumaz, 2014), ilkokul 4. sınıf düzeyinde öğrenci başarısıyla ilişkili olarak farklı öğretim yöntem ve tekniklerin etkisini inceleyen (Ayvaz, 2010; Güngör, 2014; Kılıç-Özün, 2010; Selçuk, 2015) araştırmalar da bulunmaktadır.

Eğitim kalitesinde kritik derecede önemli olan ve başarıyı doğrudan etkileyebilen unsurlardan birisi, okulda bulunan ve derslere yönelik kaynakların kapsamlılığ ve kalitesidir (Lee \& Barro, 2001; Lee \& Zuze, 2011). Bugüne kadar yapılan TIMSS çalışmalarının sonuçları, derslerde kaynak sıkıntısı çekmeyen öğretmenlerin öğrencilerinin genellikle daha başarılı olduğunu göstermektedir (Hooper ve diğerleri, 2013). Sinıf içi değişkenler kavramı, Blömeke, Olsen ve Suhl (2016) öğretmen niteliği ve öğretim kalitesinin öğrenci başarılarıyla olan ilişkileri konusundaki çalışmalarında kullanılmıştır. Öğretmenlerin sahip oldukları nitelikler, bilgi-beceri düzeyleri ve algıları öğrenci başarılarının arttırılması hususunda önemli bir faktördür. Sınıf içi süreçlerde tartışmalar, verilen cevapların açıklanması ve ödevler önceden planlaması gereken unsurlardır. Ödev konusu, pek çok araştırmacı tarafından başarıya olan etkisini görmek için araştırılan önemli bir faktördür. Trautwein (2007), ödev verilme sıklığı ve ödevlere harcanan süre konusunda yapılan araştırmaların varlığından bahsederek özellikle ödevlerin sınıf içi süreçlerde etkili kullanımının akademik başarı üzerindeki etkisine yönelik çalışmalara ihtiyaç olduğunu belirtmektedir.

Literatürde öğrenci başarılarının öğrenci, okul, sınıf ve öğretmen gibi farklı düzeyde yer alan belirleyiciler ile ilişkilerini araştıran çalışmaların birçoğu (Acar, 2013; Aktaş, 2011; Akyüz, 2006; Atar, 2014; Ekinci-Vural, 2012; Fullarton, Lokan, Lamb, \& Ainley, 2003; İpekçioğlu-Önal, 2015; Mohammadpour \& Abdul Ghafar, 2014; Sezer, 2016; Stemler, 2001; Taştekinoğlu, 2014; Yaman, 2004) sınıf düzeyindeki özelliklerin başarıya olan etkisini göz ardı etmektedir.

Ayrıca, yurt içi ve yurt dışında yapılan ve TIMSS gibi geniş ölçekli testlerin sonuçları üzerinde öğrenci, öğretmen ve okul özelliklerinin incelendiği çalışmalara (Akkuş, 2014; Aktaş, 2011; Akyüz, 2006; Atar, 2014; Aydın, 2015; Çavdar, 2015; Erşan, 2016; İpekçioğlu-Önal, 2015; Kaya, 2008; Korkmaz, 2012; Sevgi, 2009; Stemler, 2001; Yatağan, 2014) bakıldığında başarının yalnızca öğrenciden kaynaklı faktörler (Kunuk, 2015); öğrenci ve öğretmenden kaynaklı faktörler (Akyüz, 2006; İpekçioğlu-Önal, 2015; Kaya, 2008) yalnızca öğretmen kaynaklı faktörler (Aktaş, 2011; Atar, 2014; Sezer, 2016; Yaman, 2004); yalnızca okul kaynaklı faktörler (Stemler, 2001) veya okul ve 
öğrenciden kaynaklı faktörler (Acar, 2013; Aydın, 2015; Fullarton ve diğerleri, 2003; Lamb \& Fullarton, 2002; van den Broeck, Opdenakker, \& van Damme, 2005; Yatağan, 2014) ile ilişkileri bağlamında incelendiği görülmektedir. Yurt dışında yapılan bazı çalışmalarda ise (Blömeke, Suhl, \& Kaiser, 2011; Hooper ve diğerleri, 2013; Kyriakides, 2006; Martin, Mullis, Foy ve diğerleri, 2016; OECD, 2013) başarının sadece öğrenci ve okul düzeylerinde yer alan değişkenlerin birbiriyle etkileşimi ile ilişkileri araştırılmıştır.

Ancak yapılacak olan çalışmalarda başarıya etki edebilecek ve farklı düzeylerde yer alan bütün değişkenlerin derinlemesine ve birbiriyle ilişkili olarak araştııılması gereklidir. Başarının, zihinsel aktivitelerin etkin olduğu süreçler sonunda ulaşılan bir hedef olması ise bu gerekliliğin bir kanıtıdır (Nilsen ve diğerleri, 2016). Zihnin çok yönlü yapısı, başarının, sadece standart testlerle ölçülemeyecek kadar kompleks bir kavram olmasını ve dolayısıyla farklı bağlamlarda incelenerek derinlemesine araştırılmasının gerekliliğini ortaya koymaktadır. Örneğin, Creemers ve Kyriakides (2006), özellikle öğrencilerin sınıflar içinde, sınıfların okullar içinde ve okulların ülkeler içinde kümelendiği geniş ölçekli testlerin bu katmanlı örneklem yapısının, öğrenci başarılarının öğrenci, sınıf ve okul özellikleriyle ilişkili olarak değişebileceği ve bu bağlamların içerdiği koşullardan etkileneceğini belirtmektedir. Dolayısıyla, başarının bu koşulların ortaya çıktığı şartlar içerisinde ele alınarak değerlendirildiği çok yönlü araştırmaların gerçekleştirilmesi önemlidir.

Türkiye'de bu konuda yapılan araştırmalarda (Akkuş, 2014; Aktaş, 2011; Atar, 2014; Aydın, 2015; Ayvaz, 2010; Çavdar, 2015; Çelebi ve diğerleri, 2014; Erşan, 2016; Güngör, 2014; Kılıç-Özün, 2010; Korkmaz, 2012; Selçuk, 2015; Sezer, 2016) öğrenci niteliklerinden beslenme, devamsızlık ve teknoloji kullanımı ile sınıf içi değişkenlerden kaynaklar, sınıf içi tartışmalar ve ödevlerin bir arada ele alınmadığı göz önüne alındığında bu konuda bir boşluğun olduğu anlaşılmaktadır. Dolayısıyla bu araştırma, öğrenci ve sınıf düzeyinde seçilmiş bu değişkenlerin bir arada öğrencilerin fen başarısına olan etkisine odaklanmaktadir.

\section{Araştırmanın Amacı}

$\mathrm{Bu}$ araştırmanın genel amacı, öğrenci ve sınıf düzeyinde farklı değişkenleri bir araya getirerek, bu değişkenlerin 4. sınıf öğrencilerinin TIMSS fen başarısı üzerine hangi önem derecesinde etki ettiğini Hiyerarşik Lineer Model yardımıyla kestirmektir. Ayrıca okullar arası başarı varyansını en çok açıklayan öğrenci nitelikleri ve sınıf içi değişkenlerin belirlenmesi çalışmanın bir diğer amacıdır. Bu amaçlar doğrultusunda aşağıdaki sorulara cevap aranmıştır.

Araştırma soruları:

1.Öğrencilerin fen başarıları bakımından sınıflar arasında manidar farklılıklar var mıdır?

2. Öğrencilerin fen başarı puanları sınıf düzeyinde ele alınan sınıf içi değişkenlere göre farklılık göstermekte midir? Farklılık var ise bu farkı açıklayan sınıf düzeyi değişkenleri nelerdir? Etkisi manidar bulunan değişkenler fen başarı puanlarındaki varyansın ne kadarını açıklamaktadır?

3. Öğrencilerin fen başarı puanları öğrenci düzeyinde ele alınan öğrenci niteliklerine göre farklılık göstermekte midir? Farklılık var ise bu farkı açıklayan öğrenci düzeyi değişkenleri nelerdir? Etkisi manidar bulunan öğrenci düzeyi değişkenleri fen başarı puanlarındaki varyansın ne kadarını açıklamaktadır?

\section{YÖNTEM}

Bu araştırmada, TIMSS 2015 uygulaması kapsamında ele alınan 4. sınıf öğrencilerine ilişkin, çeşitli öğrenci ve sınıf özelliklerinden TIMSS 2015'te ölçülen fen başarısına etki eden değişkenlerin belirlenmesi ve karşılaştırılması amaçlandığından nicel araştırma yöntemlerinden nedensel karşılaştırma deseni kullanılmıştır. Nedensel karşılaştırma çalışmaları, ortaya çıkmış/var olan bir durumun veya gruplar arasındaki farklılıkların nedenlerini, bu durumun oluşmasında nelerin etkili 
olduğunu bir başka değişle sonuçla ilgili değişkeni etkileyen nedensel değişkenleri ya da etkinin sonuçlarını katılımcılar ve koşullar üzerinde herhangi bir müdahale olmaksızın belirlemeyi amaçlayan araştırmalardır (Büyüköztürk, Kılıç-Çakmak, Akgün, Karadeniz, \& Demirel, 2011; Fraenkel, Wallen, \& Hyun, 2012).

\section{Örneklem}

TIMSS 2015 uygulamasına Türkiye'den 4. sınıf düzeyinde 242 okuldan 6456 öğrenci ve öğrencilerin sınıf öğretmenleri ( $n=249)$ katılmıştır (LaRoche \& Foy, 2016). TIMSS 2015 örneklem seçiminde iki aşamalı tabakalı örnekleme metodu kullanılmıştır. İlk aşamada, okullar; ikinci aşamada ise bu okullardan rastgele sinıflar seçilmiştir.

Mevcut araştırmanın TIMSS 2015'e katılan bütün 4. sınıf öğrencileri ve bu öğrencilerin sınıf ögretmenlerine $(n=249)$ ilişkin veriler ile gerçekleştirilmesi amaçlanmıştır. Ancak veri dosyasında örneklemden elde edilen verilerde eksikliklerin bulunduğu görülmüsstür. Dolayısıyla örnekleme son şeklini vermek amacıyla eksik değerlere ilişkin Kayıp Veri Analizi (Missing Value Analysis) yapılmıştır.

Bu analiz sonucunda Little's MCAR testinin manidar $(<.05)$ bulunması ile veri dosyasında mevcut kayıp verinin sistematik bir dağılım gösterdiği anlaşılmıştır. Bu tür durumlarda, kayıp veri \%5'in altında ise listwise yöntemi uygulanabilmektedir (Garson, 2008). Bu doğrultuda, veri setinde her bir öğrenci için her bir değişkendeki kayıp oranına bakılmış ve \%5 üzerinde olanlar bulunduğu için listwise yöntemi tercih edilmemiştir.

“\%5'in üzerinde ve sistematik dağılan kayıp değerleri ele almanın alternatiflerinden biri kayıp değerlere ilişkin kestirimler yapma/yaklaşık bir değer atama (Imputation)'dır. Bu işlem ancak nicel veriler için yapılabilmektedir" (Çokluk, Şekercioğlu, \& Büyüköztürk, 2018, s. 11). Bu işlemleri yapmanın en yaygın üç yöntemi geçmiş bilgileri kullanmak, ortalama değer atamak ve regresyondur (Çokluk ve diğerleri, 2018; Mertler \& Vannatta, 2005; Tabachnick \& Fidell, 2001). "Araştırmacı uzun süredir bir araştırma üzerinde çalışmıyor ve başka bilgilere sahip değilse bu durumlarda ortalama değer atamak en iyi kestirim yöntemidir" (Çokluk ve diğerleri, 2018, s. 11). Dolayısıyla, bu yöntem tercih edilmiş; elde edilen verilerden yararlanarak ortalama hesaplanmış ve kayıp değer içeren değişkenlere bu ortalamalar atanmıştır.

Son durumda 6348 öğrenci ve 241 sınıf öğretmeni mevcut araştırmanın örneklemini oluşturmuştur. Ayrıca, çalışmada seçilen örneklemdeki bütün öğrencilerin ve öğretmenlerin eşit oranla temsillerinin sağlanabilmesi için, TIMSS 2015 veri dosyasında yer alan öğrenci ve öğretmenlerin ağırlıklandırma değerlerinden yararlanılmıştır.

\section{Veri Toplama Araçları}

\section{Fen başarı testi}

Fen başarı testi, yarısı çoktan seçmeli ve diğer yarısı çok kategorili olarak puanlanan maddelerden oluşmaktadır. Çoktan seçmeli maddeler, dört seçeneklidir ve bir doğru cevabı vardır. Her bir çoktan seçmeli maddenin doğru cevabı 1 puandır. Yanlış cevaplar doğru cevapları etkilememektedir. Çok kategorili olarak puanlanan maddelerde ise öğrenci kendi cevabını oluşturmaktadır. Bu soru türünde öğrenciler açıklama yaparlar, cevaplarını sözel ya da sayısal olarak desteklerler, şekiller çizerler ya da verileri kullanırlar. Çok kategorili olarak puanlanan maddeler, her bir madde için geliştirilen puanlama k1lavuzları ile değerlendirilir (Martin, Mullis, \& Foy, 2013). Bu puanlama kılavuzları, her bir madde için uygun ve eksiksiz bir cevabın temel özelliklerini içermektedir. Kılavuzlar, maddenin değerlendirdiği davranış türünün kanıtlarına odaklanır. Kısmen veya tamamen doğru olan öğrenci cevapları açıkça kılavuzda tanımlanmıştır ve bu cevaplar 0-1-2 veya 3 şeklinde puanlanır. Buna ek olarak, kılavuzda yer alan olası farklı öğrenci yanıtları da uzmanlara rehberlik eder. Çok kategorili 
olarak puanlanan maddeler puanlanırken, öğrencilerin yazma yeteneklerine değil yalnızca değerlendirilen konunun gerektirdiği becerilere odaklanılır (Martin ve diğerleri, 2013).

Maddeler öğrenme alanlarına \%45 canlı bilimleri, \%35 fiziksel bilimler ve $\% 20$ yer bilimleri şeklinde dağılmıştır. Ayrıca, maddelerin \%40'1 bilme, \%40'1 uygulama ve \%20'si akıl yürütme şeklinde bilişsel alan dağılımı göstermektedir (Martin ve diğerleri, 2013).

Olası değerler: TIMSS'te yar alan fen soruları toplam 14 farklı test kitapçı̆̆ından oluşmaktadır. Her iki test kitapçığında bir ortak soru bulunacak şekilde bir madde örüntüsü geliştirilmiştir. Dolayısıyla, her bir öğrencinin aynı maddeler üzerinde test edilmesi mümkün olmamaktadır. Her bir öğrencinin fen başarı puanı öğrenci sanki bütün maddeleri yanıtlamış gibi tahmin edilir. Bu noktada, gözlemlenen her bir skordan ziyade, her bir öğrencinin yeterliliği için tahmin edilen olası değerler aralığı veya dağılımıdır. TIMSS veri dosyasında, her bir öğrencinin fen başarı puanı için 5 olası değer (plausible value, PVSCI1-5) raporlanmıştır (Martin, Mullis, Hooper ve diğerleri, 2016). Mevcut araştırmanın sonuç değiş̧keni olan TIMSS fen başarısının göstergeleri olarak fen başarı testi uygulaması sonucunda elde edilen bu olası değerler kullanılmıştır. HLM programı bu 5 olası değeri çoklu veri atama yaparak aynı anda analize dahil etmekte ve ortalama bir değer atamaktadır. Dolayısıyla araştırma kapsamında, her bir öğrencinin fen testi ile ilgili olarak PV1SCI-PV5SCI aralığında yer alan olası değerlerin ortalaması alınarak analizler gerçekleştirilmiştir.

\section{Ögretmen anketi}

Araştırmanın sınıf düzeyinde yer alan bütün değişkenleri öğretmen anketi ile elde edilmiştir. $\mathrm{Bu}$ ankette yer alan 21 maddeden 10'u fene ilişkindir ve sınıf öğretmeni tarafından doldurulmuştur. Mevcut araştırma için ilgili literatür doğrultusunda öğretmen anketi veri dosyasında yer alan maddelerden Akademik başarıda okulun önemine ilişkin algı, Güvenli ve düzenli okul yapısına ilişkin algı, okul imkan ve kaynakları ile ilgili problemler, karşılaşılan güçlükler, öğrenci ihtiyaçları ile sınırlı öğretim, öğrencilerin fen ödevlerine geri bildirim verme, fen ödevlerini sinıfta tartışma, fen ödevlerini kontrol etme, araştırmaya verilen önem, ders-günlük yaşam bağlantısı, cevapların sınıfta açıklanması, ilgi çekici materyal kullanımı, zorlayıcı etkinliklerin tamamlanması, sınıf içi tartışmalar, yeni içerikönceki içerik bağlantısı, problem çözme sürelerine karar verme, düşüncelerini açıklama değişkenler olarak belirlenmiştir

\section{Ögrenci anketi}

Öğrenci düzeyinde yer alan değişkenler öğrenci anketi ile elde edilmiştir. Öğrenciler tarafindan doldurulan bu anket, ögrencilerin ev ve okul yaşantılarına, kendileri ile ilgili algılarına, matematik ve fen derslerine yönelik tutumlarına, ev ödevlerine ve okul dışı etkinliklere, bilgisayar kullanımlarına, evde öğrenmeye ilişkin kaynaklara ve genel kişisel bilgilere yönelik 10 maddeden oluşmaktadır (Hooper ve diğerleri, 2013). Mevcut araştırma için ilgili literatür doğrultusunda TIMSS 2015 öğrenci anketi veri dosyasında yer alan maddelerden cinsiyet, devamsızlık, beslenme, evde teknoloji kullanımı, okulda teknoloji kullanımı ve diğer yerlerde teknoloji kullanımı değişkenler olarak belirlenmiştir.

Ölçümlerin güvenirliği: TIMSS 2015 öğrenci ve öğretmen anketlerinde fen başarısı ile ilgili olduğu düşünülen özellikleri ölçmek amacı ile Likert tipi derecelendirmenin kullanıldığı maddeler yer almaktadır. $\mathrm{Bu}$ anket maddelerine verilen yanıtlara dayalı olarak, TIMSS uzmanları tarafindan ConQuest 2.0 programı kullanılarak Madde Tepki Kuramına dayalı analizler yapılmış ve ölçülmek istenen yapıya ilişkin ölçümler elde edilmiştir. Bu ölçümler her bir yapıya ilişkin olarak ortalama 10, standart sapma 2 olacak şekilde belirlenmiştir (Martin, Mullis, Hooper ve diğerleri, 2016). Mevcut araştırma kapsamında belirlenen ölçek maddeleri, TIMSS teknik ekibi tarafından Madde Tepki Kuramı çerçevesinde Rasch Kısmi Puan Modeli ile incelenmiştir.

Ölçeklerin ülkeler arasında karşılaştırılabilir ölçümler sağladığına dair kanıt olarak, her ülke için her bir ölçeğe ilişkin güvenirlik katsayıları hesaplanmış ve ölçek maddelerinin temel bileşen analizi 
(principal components alaysis) yapılmıştır. Bu doğrultuda yapılan analizler sonucunda ortaya konan raporlar, TIMSS 2015 ölçeklerinin genelde kabul edilebilir bir seviyede ve Cronbach Alfa değerlerinin .70'ten yüksek olduğunu göstermiştir. Mevcut araştırmada kullanılan ölçeklerin güvenirliğine ilişkin değerler Tablo 1.'de (Martin, Mullis, Hooper ve diğerleri, 2016) belirtilmiştir.

\section{Verilerin Analizi}

Çalışmanın verilerinin analizinde iki düzeyli hiyerarşik lineer modelleme (HLM) yöntemi kullanılmıştır. HLM'nin ilk aşaması ön analizlerdir. Bu doğrultuda, öğrenci anketinden elde edilen öğrenci düzeyi değişkenleri ve öğretmen anketinden elde edilen sınıf düzeyi değişkenleri, aşağıdaki işlemler uygulanarak çalışmanın amacına uygun şekilde düzenlenmiştir. İkinci aşamada HLM'nin varsayımları test edilmiştir. Son aşamada, HLM modelleri kurularak veriler analiz edilmiştir.

\section{Ön analizler}

Verilerin düzenlenmesi: Veri setinde değişkenler için belirlenmiş orijinal kodlar, bu araştırmanın değişkenleri için $X$, öğrenci düzeyi değişkenleri; $W$, sınıf düzeyi değişkenlerini ifade edecek şekilde yeniden kodlanmıştır. Araştırmanın amacı ve ilgili literatür doğrultusunda öğrenci ve öğretmen anketindeki bazı maddeler veriden çıkarılmıştır. Araştırmada kullanılan maddeler Tablo 1.'de yer alan, öğrenci ve sınıf düzeyinde belirlenen maddelerdir. Endeks puanı olan değişkenlerin maddeleri veriden silinmiştir.

Değişkenler arası korelasyon: Bağımlı değişken ile ilişkisi olmayan bağımsız değişkenler kontrol edilmiştir. Korelasyon değerlerinin -.08 ile .29 (.01 anlamlılık düzeyinde) aralığında değişmekte olduğu görülmüştür. Dolayısıyla veri setinden değişken silinmemiştir.

Çoklu bağlantılılık (Multicollinearity): Öğrenci düzeyinde yer alan bağımsız değişkenlerin birbirleri ile korelasyonları incelenerek çoklu bağlantılılık olup olmadığı kontrol edilmiştir. Bu ilişki düzeyinin .80 ve üzeri olması bu problemin olabileceğini gösterirken; .90 ve üzeri olması çoklu bağlantı problemi için önemli bir kanıttır (Tabachnick \& Fidell, 2001). Bu doğrultuda elde edilen korelasyon değerlerinin ortalama -.07 ile .34 (.01 anlamlılık düzeyinde) aralığında değişmekte olduğu görülmüştür. Sonuçlara göre, dosyadan herhangi bir değişken silinmemiştir.

Kayıp verilerin incelenmesi (Missing value analysis): Bu bölüm “örneklem” kısmında açıklanmıştır.

Uç değer ayıklama: Bilimsel araştırmalarda, herhangi bir deneğin örneklemin geri kalan kısmından farklılaşması uç değere temel teşkil etmektedir. Mevcut çalışmada, sürekli değişkenlere ait değerler Z puanlarına çevrilerek \pm 4 puan dışarıda kalan değerin olup olmadığı kontrol edilmiştir (Tabachnick \& Fidell, 2001; Mertler \& Vannatta, 2005). Uç değerlerin veri setinden ayıklanması sonucunda örneklem 6378 öğrenci ve 241 öğretmenden meydana gelmiştir.

Açımlayıcı analiz: Sınıf düzeyi değişkenleri için Açımlayıcı Analiz (Exploratory Analysis) yapılmıştır. Açımlayıcı analiz HLM programının seçeneklerinden biri olup; modele hangi değişkenlerin dahil edilmesinin uygun olduğuna karar vermenin bir dayanağıdır. Analizde elde edilen t değerinin mutlak değer 1'den büyük olması durumunda ilgili değişken analize dahil edilebilir (Raudenbush \& Bryk, 2002). Bu analizde Fen başarısıyla ilişkili 15 değişkene aynı anda bakılmış ve sonuçta 11 değişkenin $t$ değeri manidar (-1.23 ile 10.26 aralığında değişmektedir) bulunmuştur. $t$ değeri manidar bulunan bütün değişkenler modele dahil edilmiştir. $t$ değeri anlamlı olmayan değişkenler [sınıfta ödevleri kontrol etme (0.57), ders-günlük yaşam bağlantısı (0.96), zorlayıcı etkinliklerin tamamlanması (-0.31), ders sırasında düşünceleri açıklama (-0.84)] analizden çıkarılmıştır. Ön analizler neticesinde öğrenci düzeyinde 6; sınıf düzeyinde 11 değişken yer almıştır. 


\section{HLM analizi}

HLM, özellikle eğitim alanında elde edilen hiyerarşik (aşamalı) verilerin yapısına uygun olarak gerekli analizleri gerçekleştiren ve iç içe geçmiş rastgele etkileri içeren çok düzeyli bir regresyon tekniğidir (Raudenbush \& Bryk, 2002). Sosyal bilimlerde gerçekleştirilen araştırmalarda elde edilen verilerin büyük bir çoğunluğu örneklem yapısı veya örnekleme tekniklerinden ötürü hiyerarşik olarak nitelendirilen bir yapıdadır. Mevcut çalışmanın konusu olan TIMSS uygulamasında da öğrenciler sınıflarda, sınıflar okullarda, okullar bölgelerde ve bölgeler de ülkelerde kümelenmek üzere hiyerarşik bir yapı sergilemektedir. Hiyerarşik Lineer Model, aynı anda gruplanmış verilerin hiyerarşik düzeyleri arasındaki ilişkileri araştırır ve bu şekilde tek düzeyli analiz yöntemlerinden farklı olarak düzeylerdeki değişkenler arası farkı hesaplamada daha verimli hale getirir (Raudenbush \& Bryk, 2002). Bu konudaki literatürde (Heck \& Thomas, 2009; Hox, 2002; Raudenbush \& Bryk, 2002) TIMSS gibi, verilerin farklı düzeylerden elde edildiği çalışmalarda verilerin analizi için çok düzeyli modellerin kullanılması tavsiye edilmektedir. Hox (2002), böyle çalışmalarda verilerin analizi için tek düzeyli modellerin uygulanmasının istatistiki ve kavramsal problemler doğuracağını belirtmektedir.

Tek düzeyli analiz yöntemleri gözlemlerin bağımsılığı ve varyansların homojenliği (homoscedasticity) varsayımlarının sağlanmasını gerekli kılmaktadır. Geniş örneklemlerden elde edilen verilerde ise bu varsayımlar ihlal edilebilmektedir. Ozborne (2002), hiyerarşik yapılı bir desende farklı gruplara ilişkin elde edilen verilerin, bulundukları düzeyde birbirine daha fazla benzeme eğilimi gösterdiğini belirtmektedir. Örneğin, belli bir sınıftaki öğrenciler farklı sınıftaki öğrencilere göre aynı olanakları paylaştıkları için birbirlerine daha fazla benzemektedir. Bu durumda aynı birimde yer alan öğrencilerden elde edilen gözlemlerin birbirinden tamamen bağımsız olması olanaksızdır. Dolayısıyla, gözlemlerin bağımsızlığı varsayımın ihlal edilmemesi için iç içe geçmiş yapıda verilerin analizinde çok düzeyli modellerin kullanılması daha doğru olacaktır. Diğer önemli bir konu, varyansların homojenliği varsayımı ihlalidir (Hox, 2010). Geniş örneklemlerde bir sınıf homojen yapı göstermekte iken, diğer sınıf heterojen yapıda olabilir. Çok düzeyli modeller, bağımlı değişkene ilişkin grup-içi ve gruplar-arası varyansın hesaplanmasına olanak tanımaktadır; dolayısıyla düzeylerin etkilerinin anlaşılması mümkün görülmektedir.

Ayrıca hiyerarşik yapıda olan verilerin analizinde tek düzeyli analiz yöntemlerinin kullanılması, regresyon katsayı kestirimlerine ait standart hataların olması gerektiğinden daha küçük hesaplanmasına da neden olabilmektedir. Bu durum, kestirilen regresyon katsayılarının önem derecelerinin daha yüksek tahmin edilmesine (overestimation) sebep olur (Raudenbush \& Bryk, 2002). Çok düzeyli modellerde ise bu durum her bir düzeye rastgele etki katsayısı $\left(u_{\mathrm{qj}}\right)$ dahil edilerek ortadan kaldırılabilir. Böylece, rastgele etkilerdeki değişkenlik de göz önünde bulundurularak standart hatalar doğru kestirilebilmektedir. Bu durum, çok düzeyli modelin sağladığı bir diğer avantajdır.

Sonuç olarak, "Hiyerarşik Lineer Model, açıklanan farklı konularda tek düzeyli modellere göre sağladığı avantajlardan ötürü" (Raudenbush \& Bryk, 2002, s. 3-6) ve mevcut araştırmanın veri yapısına uygun olması (Hox, 1995) dolayısıyla verilerin analizinde tercih edilmiştir.

HLM'de düzeylerin belirlenmesi: Hiyerarşik yapı gösteren verilerle çalışırken, değişkenler arası ilişkilerin incelenmesinde ele alınacak düzeyin belirlenmesi, önemli görülen ve dikkat edilmesi gereken bir aşamadır. HLM analizinde kullanılan hiyerarşik kategori sayısı yapılan analizin isimlendirilmesinde kullanılır. Öğrencilerin sınıflarda kümelendiği durumlarda yapılacak analizlerde, öğrencilere ait değişkenler öğrenci düzeyi; sınıflara ait değişkenler sınıf veya okul düzeyinde yer alabilir (Nilsen ve diğerleri, 2016). Bu duruma da iki düzeyli veri yapısından ötürü İki Düzeyli Hiyerarşik Lineer Modelleme denir (Toraman, Akay, Özdemir, \& Karadağ, 2011). Mevcut araştırmada TIMSS 2015 veri setinden çekilen bağımsız değişkenler HLM analizine dahil edilmek üzere öğrenci düzeyi ve sınıf düzeyi olarak iki temel kategoride tanımlanmıştır.

Araştırmanın değişkenlerinin belirlenmesi: Uluslararası düzeyde gerçekleştirilen TIMSS'e dayalı çalışmaların bir kısmında (Kyriakides, 2006; Lamb \& Fullarton, 2002; Nilsen ve diğerleri, 2016; Webster \& Fisher, 2000) başarı ile ilişkili öğrenci ve sınıf düzeyindeki değişkenlerin literatürdeki farklı okul öğrenme modellerine dayandırıldığı görülmektedir. Türkiye'de ise, gerçekleştirilen TIMSS'e dayalı araştırmalar arasında öğrenci ve sınıf düzeyinde ele alınan değişkenlerin 
belirlenmesinde kuramsal olarak farklı modellerden yararlanan çalışmalar (Akyüz, 2006; Aydın, 2015; İpekçioğlu-Önal, 2015) vardır. Örneğin, Akyüz (2006), öğrencilerin matematik başarılarıyla ilişkili olarak öğretmen ve öğrenci anketinden belirlediği değişkenleri, TIMSS 1995 çalışmasının kuramsal çerçevesini oluşturan teorik yapı temel alarak hazırlamış; Matematik ve Fen olanakları Anketi (Survey of Mathematics and Science Opportunitues -SMSO)'ne dayandırarak incelemiştir. Benzer şekilde Aydın (2015), çalışmasında, farklı kuramsal modelleri inceleyerek öğrenci ve okul düzeyindeki faktörlerin öğrenci başarılarındaki etkilerine ilişkin yeni bir model önermiştir. Bu model, TIMSS 2011 uygulamasının teorik değerlendirme çerçevesine dayalı olarak oluşturulmuştur. İpekçioğlu-Önal (2015), çalışmasında, öğrencilerin fen başarısına ve fene karşı tutumlarına öğrenci ve öğretmen düzeyinde etkileyen faktörleri incelemek amacıyla, bu konuda ortaya konan önceki çalışmalardan yola çıkarak yeni bir model geliştirmiştir. Bu modelde, öğrencilerin fen başarılarında ve fene karş1 tutumlarında öğrenci düzeyinde: cinsiyet, ödevlere ayrılan zaman, akran zorbalığı, ailenin katılımı ve evdeki eğitsel kaynaklar; öğretmen düzeyinde: fen öğretiminde özgüven, mesleğe adanmışlı, meslektaşlarla iş birliği, fen deneylerine vurgu, tecrübe ve profesyonel gelişim faktörleri bir araya getirilmiştir.

Sonuç olarak, fen alanında başarıya hangi faktörlerin etki ettiğine dair yapılan çalışmalarda, öğrenci ve sınıf düzeyinde çeşitli faktörleri öğrenci başarılarıyla ilişkili olarak ele alan farklı modeller geliştirilmiştir (Lamb \& Fullarton, 2002). Bu bilgiden yola çıkarak denilebilir ki, sadece tek bir model, öğrenci çıktıları ile farklı pek çok değişken arasındaki ilişkiyi tam olarak açıklayamaz. Bu konuda gerçekleştirilecek bir çalışmada değişkenlerin belirlenmesinde, farklı modellerle denenmiş ve kanıtlanmış değişkenler üzerinden oluşturulan bir çerçevenin tercih edilmesi istatistiksel ve kuramsal olarak daha yararlı olabilir (Hox, 2010).

Bu nedenle, mevcut araştırmada, öğrenci ve sınıf düzeyine, hangi değişkenlerin dahil edileceğine karar vermek için, literatürde yer alan farklı öğrenme modelleri, TIMSS değerlendirme çerçevesi ve Nilsen ve diğerleri (2016), tarafından geliştirilen, Öğrenci Çıktılarının Belirleyicilerine İlişkin Kavramsal Yap1 (Conceptional framework of determinants of students outcomes) incelenmiş ve bu incelemelerin sonucunda araştırmanın değişkenleri şekillenmiştir. Bundan yola çıkarak öğrenci düzeyinde 6; sınıf düzeyinde 17 olmak üzere toplamda 21 bağımsız değişken belirlenmiştir. Tablo 1 , çalışmanın değişkenlerine ilişkin detaylı bilgiyi içermektedir.

Tablo 1. Araştırmanın Ön Analizler Öncesinde Belirlenen Değişkenleri

\begin{tabular}{|c|c|c|c|c|c|c|}
\hline $\begin{array}{l}\text { Kavramsal } \\
\text { Grup }\end{array}$ & $\begin{array}{l}\text { Sınıf Düzeyi (Düzey-2) } \\
\text { Değişkenleri }\end{array}$ & Dönüştürme & $\begin{array}{l}\text { TIMSS } \\
\text { Kodu }\end{array}$ & $\begin{array}{l}\text { Araştırma } \\
\text { Kodu }\end{array}$ & Güvenirlik* & $\begin{array}{l}\text { Açıllanan } \\
\text { Varyans }\end{array}$ \\
\hline \multirow{2}{*}{ Okul Ortamı } & $\begin{array}{l}\text { Akademik başarıda okulun } \\
\text { önemine ilişkin alg1 }\end{array}$ & Evet & ATBG06A-R & W12 & .90 & 45 \\
\hline & $\begin{array}{l}\text { Güvenli ve düzenli okul } \\
\text { yapısına ilişkin alg1 }\end{array}$ & Evet & ATBG07A-H & W13 & .89 & 57 \\
\hline \multirow{2}{*}{$\begin{array}{l}\text { Çalışma } \\
\text { Koşulları }\end{array}$} & $\begin{array}{l}\text { Okul imkan ve kaynakları } \\
\text { ile ilgili problemler }\end{array}$ & Evet & ATBG08A-G & W14 & .89 & 60 \\
\hline & Karşılaşılan güçlükler & & ATBG11A-H & W15 & .76 & 35 \\
\hline \multirow{5}{*}{$\begin{array}{l}\text { Öğretim } \\
\text { Uygulamaları }\end{array}$} & $\begin{array}{l}\text { Öğrenci ihtiyaçları ile sınırlı } \\
\text { öğretim }\end{array}$ & Evet & ATBG15A-G & W16 & .73 & 43 \\
\hline & Verilen Ödevler (3) & Hayır & $\begin{array}{l}\text { ATBS06CA- } \\
\text { CB }\end{array}$ & $\begin{array}{l}\text { W18A- } \\
C^{* *}\end{array}$ & - & - \\
\hline & Araştırmaya verilen önem & Evet & ATBS03A-K & W19 & .88 & 47 \\
\hline & $\begin{array}{l}\text { Öğretime katılım/Öğretimin } \\
\text { kalitesi (8) }\end{array}$ & Hayır & ATBG14A-H & $\begin{array}{l}\text { W20A- } \\
\mathrm{H}^{* *}\end{array}$ & - & - \\
\hline & $\begin{array}{l}\text { Öğrenci Düzeyi (Düzey-1) } \\
\text { Değişkenleri }\end{array}$ & & & & & \\
\hline \multirow{4}{*}{$\begin{array}{l}\text { Öğrenci } \\
\text { Nitelikleri }\end{array}$} & Cinsiyet & Hayır & ITSEX & $\mathrm{X} 8 * * *$ & & \\
\hline & Devamsızlık yapmama & Hayır & ASBG08 & $\mathrm{X} 9 * *$ & & \\
\hline & Kahvalt1 yapmama & Hayır & ASBG09 & $\mathrm{X} 10 * *$ & & \\
\hline & Teknoloji kullanımı (3) & Hayır & ASBG10A-C & $\begin{array}{l}\mathrm{X} 11 \mathrm{~A}- \\
\mathrm{C}^{* *}\end{array}$ & & \\
\hline
\end{tabular}


Tablo 1'de yer alan değişkenlerle ön analizlerin gerçekleştirilmesinin ardından, öğrenci düzeyinde 6; sınıf düzeyinde 11 değişken olmak üzere toplamda 17 değişken ile modeller kurulmuştur. Çalışmanın bağımlı değişkeni ise, TIMSS 2015 fen başarı puanlarıdır. Bağımsız değişkenlerden benzer özellik gösterenler literatüre dayanarak ve sonuçların yorumlanması açısından kavramsal gruplara ayrılmıştır. Tablo 1'de gösterildiği üzere öğrenci düzeyi 1, sınıf düzeyi ise 3 kavramsal gruptan oluşmuştur.

Araştırmanın değişkenlerine ilişkin TIMSS uygulamalarında kullanılan ölçekler, 1-4 arası puanlanmış tepki kategorilerinden [çok katıllyorum (1), az katılıyorum (2), katılmıyorum (3), hiç katılmıyorum (4)] oluşan anketler veya indeks verileri sonucu 1-3 şeklinde [örneğin: az (3), orta düzeyde (2), fazla (1)] puanlanmıştır. Ancak, verilerin analizlerde kullanılabilmesi için bu puanlar, gerçek aralıklar hesaplanarak kesme noktaları dikkate alınarak ölçekler dönüştürülmüştür (Aydın, 2015). Bu çalışmada dönüştürülmüş ölçeklerden elde edilen sürekli değerler ile analizler yürütülmüştür. Bu yaklaşım, ölçülen psikolojik özelliğin sayısal verilerle tanımlanması ve özellikle yorumlanması anlamında bir takım istatistiki zorlukların önüne geçilmesini sağlayabilir. Örneğin,

Gerçek aralıklar hesaplanarak sürekli forma dönüştürülen akran zorbalığı ölçeği için 9.6 ve 8 kesim noktaları olarak belirlenmiştir. Öğrencilerin akran zorbalığına uğrama düzeyleri neredeyse hiç ( < 8), ayda bir kez ( < 9.6 ve > 8) ve haftada bir kez (> 9.6) şeklinde tanımlanmıştır. (Martin, Mullis, Hooper ve diğerleri, 2016, s. 15.89)

Tanımlanan bu değerlerin kullanılması (örneğin akran zorbalığına uğrama değişkeni) ölçülmesi hedeflenen tutum, değer vb. psikolojik yapıların istatistiki olarak tanımlanıp yorumlanması açısından kolaylık sağlamaktadır.

Cinsiyete ilişkin değişken kategoriktir. Sürekli forma dönüştürülmemiş ve örtük özellik gösteren bazı değişkenlere (verilen ödevler, teknoloji kullanımı, öğretime katılım/öğretimin kalitesi) ilişkin ölçümlerde her bir madde ayrı bir değişken olarak ele alınmıştır. Bazı değişkenlere ilişkin ölçümler süreksizdir. HLM analizine dahil edilen değişkenlere ilişkin betimsel istatistikler Tablo 2'de yer almaktadir.

Tablo 2. HLM Analizine Dahil Edilen Değişsenlere İlişkin Betimsel İstatistikler

\begin{tabular}{|c|c|c|c|c|c|}
\hline Değişkenler & $\mathrm{N}$ & Ortalama & SD & Minimum & Maximum \\
\hline $\mathrm{X} 8$ & 6378 & 1.51 & 0.50 & 1.00 & 2.00 \\
\hline X9 & 6378 & 3.38 & 0.96 & 1.00 & 4.00 \\
\hline $\mathrm{X} 10$ & 6378 & 1.74 & 1.04 & 1.00 & 4.00 \\
\hline $\mathrm{X} 11 \mathrm{~A}$ & 6378 & 2.34 & 1.21 & 1.00 & 4.00 \\
\hline $\mathrm{X} 11 \mathrm{~B}$ & 6378 & 2.77 & 1.29 & 1.00 & 4.00 \\
\hline $\mathrm{X} 11 \mathrm{C}$ & 6378 & 2.59 & 1.20 & 1.00 & 4.00 \\
\hline W12 & 241 & 9.29 & 1.97 & 2.82 & 15.83 \\
\hline W13 & 241 & 9.67 & 2.16 & 3.75 & 13.41 \\
\hline W14 & 241 & 8.90 & 2.23 & 3.19 & 13.57 \\
\hline W15 & 241 & 1.05 & 0.93 & 0.00 & 3.00 \\
\hline W16 & 241 & 8.78 & 1.72 & 3.80 & 14.51 \\
\hline W18A & 241 & 1.25 & 0.45 & 1.00 & 3.00 \\
\hline W18B & 241 & 1.52 & 0.54 & 1.00 & 3.00 \\
\hline W18C & 241 & 1.18 & 0.39 & 1.00 & 3.00 \\
\hline W19 & 241 & 11.11 & 2.06 & 7.30 & 15.55 \\
\hline W20B & 241 & 1.344 & 0.60 & 1.00 & 3.00 \\
\hline W20C & 241 & 2.49 & 0.75 & 1.00 & 4.00 \\
\hline W20E & 241 & 1.34 & 0.60 & 1.00 & 4.00 \\
\hline W20F & 241 & 1.48 & 0.75 & 1.00 & 4.00 \\
\hline W20G & 241 & 1.60 & 0.80 & 1.00 & 4.00 \\
\hline PV1(ASSSCI01) & 6378 & 484.33 & 91.13 & 142.40 & 754.79 \\
\hline PV2(ASSSCI02) & 6378 & 482.38 & 92.36 & 150.67 & 745.23 \\
\hline PV3(ASSSCI03) & 6378 & 482.26 & 92.69 & 136.74 & 746.52 \\
\hline PV4(ASSSCI04) & 6378 & 481.30 & 93.80 & 69.90 & 846.24 \\
\hline PV5(ASSSCI05) & 6378 & 484.62 & 93.39 & 103.62 & 781.64 \\
\hline
\end{tabular}


HLM'nin varsayımları: Ön analizlerin tamamlanmasından sonra HLM analizi için varsayımlar kontrol edilmiştir. HLM de Düzey 1'e ilişkin ilk varsayım artıkların normalliğine dairdir. Bu aşamada ilk olarak SPSS'te oluşturulan artık dosyalar üzerinden yapılan Kolmogorov-Smirnov testi sonucu manidar bulunmuştur $(p<.001)$. Bu durumda veriler normal dağılımdan farklılık gösterdiği yorumu yapılır (Mertler \& Vannatta, 2005). Sonrasında çarpıklık ve basıklık katsayıları incelenmiştir. Normal dağılım gösteren bir veride bu değerler sıfır olarak hesaplanır. Ancak bu değerlerin \pm 1 arasında bulunması, dağılımın normalden aşırı sapmadığı şeklinde yorumlanır (Çokluk ve diğerleri, 2018). Veriye ait çarpıklık ve basıklık değerleri hesaplanmış ve sırası ile (-0.225) ve (0.250) bulunmuştur. $\mathrm{Bu}$ durumda verinin normal dağılım sergilediği görülmüştür. 1. Düzey hataların normalliğine ilişkin diğer bir istatistiksel işlem veriye ait histogramın normal eğride çizdirerek incelenmesidir. Histogram okuliçi hataların dağılımının yaklaşık olarak normal olduğunu göstermektedir, bu durumda normallik sayıltısı savunulabilir. Normallik sayıltısını kontrol etmek için özellikle 100 ve daha geniş örneklemlerde veriye ait Q-Q grafiğgi de incelenebilmektedir. Yapılan işlemde, Q-Q grafikte noktalar, köşegenler odağında bir doğru çizgisi şeklinde görülmüştür. Bu şekil normal dağılıma ilişkin bir görüntü olarak yorumlanmıştır (Mertler \& Vannatta, 2005). Son olarak, 1. Düzey artık varyansların homojenliği kontrol edilmiştir. SPSS'te yapılan işlem sonucu elde edilen saçılma diyagramı (scatter plot) incelendiğinde görülen elips şekli Düzey-1'e ait atık varyansların homojen olduğuna dair bilgi vermiştir. Varyans homojenliğine dair ayrıca HLM programında homojenlik testi (Test of Homogenety) uygulanmıştır. Bu testin sonuçlarına göre $\chi^{2}=274.93, \mathrm{sd}=239, p>.001$ şeklindedir. Düzey-1 varyanslarının homojenliği testinin manidar bulunmaması Düzey-2 birimleri arasında varyansların homojen bir şekilde dağıldığını belirtir. Dolayısıyla mevcut araştırmanın verilerine ilişkin bu varsayımın sağlandığı görülmüştür. Sonuç olarak, Düzey-1 için artıkların normale yakın ve homojen bir dağılım gösterdiği; değişkenlerin bu düzey hata terimi olan $r_{\mathrm{ij}}$ den ve diğer düzeylerdeki rastgele etkilerden bağımsız olduğu görülmüştür.

Düzey 2'e ilişkin ilk varsayım olan hataların çok değişkenli normal dağılımına ilişkin ilk aşamada SPSS'te artık dosyaları kullanılarak serpme grafikleri elde edilmiştir. Her okul için MDIST (Mahalanobis Uzaklığı) grafiği artıkların normallikten sapmasını vermiş̧ir. Kesişim ve eğim modellerinin artıkları için Q-Q ve P-P grafikleri incelenmiştir. Bu düzeydeki kesim noktası ve değişkenlere ait eğim katsayılarının normallik varsayımı için elde edilen şekillerde MDIST'e karşı CHIPT'e ait saç1lım grafiğginin, 45 derecelik bir doğruya benzemesi beklenir. Elde edilen grafik 45 derecelik bir doğruya benzemektedir. Ayrıca, Kesişim modeli için Q-Q Grafiğinin yaklaşık olarak doğrusal olduğu görülmüştür. Böylece sayıltının savunulur olduğu görülmüştür. Ayrıca sınıf düzeyi değişkenleri eğim katsayılarına ait $\mathrm{Q}-\mathrm{Q}$ grafikler incelendiğinde ikinci düzey kesim noktası katsayılarının artık değerlerinin çok değişkenli normal dağıldığı görülmüştür. Buna ek olarak, değişkenlerin eğim katsayılarına ilişkin yapılan Kolmogorov-Smirnov ve Shapiro-Wilk testi sonuçlarının manidar bulunması, ilgili katsayılar için hipotezin kabul edilir olduğunu ve verilerin normal dağılım gösterdiğini açıklamıştır.

Sonuç olarak, Düzey-2 için, bu düzeyde yer alan kesim noktası ve değişkenlere ait eğim katsayılarının normal bir dağılım gösterdiği anlaşılmıştır. Değişkenler, bu düzey hata terimi olan $u_{0 \mathrm{j}}$ den bağımsızdır. Ayrıca Düzey-2 hataları ortalaması sıfır olan çoklu normallik göstermektedir.

Varsayımların sağlanmasının ardından araştırma problemlerinin yanıtlanması ile ilgili modeller analiz edilmiş̧ir. Aşağıda bu araştırma kapsamında test edilen HLM modellerine yer verilmiştir:

1) Tek-Yönlü Varyans Analizi Rastgele Etkiler Modeli (ANOVA Modeli): Bu model ile Öğrencilerin fen başarılarındaki farlılıkların ne kadarı sinıflar arası farklılıktan kaynaklanmaktadır? sorusu cevaplanırken aynı zamanda verinin analizinde HLM'nin uygun olup olmadığ öğrenci veya sınıf düzeylerine ait hiçbir açıklayıcı değişken bulunmaz (Hox, 2002). Tek yönlü varyans analizinde bağımlı değişkene ilişkin varyans gruplar-arası ve grup-içi varyans olmak üzere ikiye ayrılır. Bu modelin 1. Düzey eşitliği aşağıdaki gibidir:

$$
Y_{i j}=\beta_{0 j}+r_{i j}
$$

Bu eşitlikte $j$ sınıfındaki $i$ öğrencisinin fen başarısı $\left(Y_{\mathrm{ij}}\right)$ tahmin edilir. $\beta_{0 \mathrm{j}}, j$ sınıfının fen başarı puanı ortalaması, $r_{i j}, j$ sınıfındaki $i$ ögrencisinin hata puanını yani $i$ öğrencisinin $j$ sınıfındaki ortalama fen 
puanından farkını ifade etmektedir. Öğrenci düzeyindeki her bir hata puanının 0 ortalama ve sabit Düzey-1 $\left(\sigma^{2}\right)$ varyansı ile normal dağıldığı varsayılır. Bu modelin 2. Düzey eşitliği aşağıdaki gibidir:

$$
\beta_{0 j}=\gamma_{00}+u_{0 j}
$$

Modelin birinci düzeyindeki kesişim katsayısının $\left(\beta_{0_{\mathrm{j}}}\right)$ bağımlı değişken olarak alındığı eşitlikte, $\gamma_{00}$ sınıfların genel fen başarı puanı ortalaması, $u_{0 \mathrm{j}}, j$ sınıfının hata puanını göstermektedir; yani $j$ sınıfının fen başarı ortalamasının genel fen başarı ortalamasından farkı olarak yorumlanır. $u_{0 \mathrm{j}} 0$ ortalama ve $\tau_{00}$ varyansla normal dağılım gösterdiği varsayılır. $u_{0 j}$ 'nin sıfıra yaklaşması, sınıflar arası değişkenliğin çok az olduğu anlamına gelir.

Birleştirilmiş model:

$$
Y_{i j}=\gamma_{00}+u_{0 j}+r_{i j}
$$

Aşağıdaki parametreler kullanılarak bağımlı değişkendeki varyansın ne kadarının birinci düzeyden ne kadarının ikinci düzeyden kaynaklandığını belirlemek amacıyla okullar arası ve okul içi korelasyon katsayıs1 (Intra Class Correlation [ICC]) $p$ hesaplanır.

$$
\begin{gathered}
\rho(\text { sınıflar arasi })=\tau^{00} /\left(\tau^{00}+\sigma^{0}\right) \\
\rho(\text { sınıf içi })=\sigma^{2} /\left(\tau^{00}+\sigma^{2}\right)
\end{gathered}
$$

2) Ortalamaların Bağımlı Değişken Olduğu Model: Araştırmanın ikinci sorusunu yanıtlamak için kurulmuştur. Bu modelin 1. Düzey eşitliği ANOVA modeli ile aynıdır ve herhangi bir öğrenci düzeyi değişken yer almaz. 2. Düzeye ise sınıf özelliklerinin öğrenci başarısını ne ölçüde tahmin ettiğini göstermek için sınıf değişkenleri eklenmiştir.

Modellerin kurulumunda, çoklu doğru bağıntı (multicollinearity) probleminin sebep olduğu yanlılık durumunun ortadan kaldırılması için merkezleme (centering) yapılmıştır (Raudenbush \& Bryk, 2002). Öğrenci düzeyinde bulunan sürekli değişkenler için grup-ortalamasında merkezleme (group-mean centering), sınıf düzeyinde bulunan sürekli değişkenler için genel-ortalamada merkezleme (grandmean centering) yapılırken, her iki düzeyde yer alan kategorik değişkenler için merkezleme (uncentering) yapılmamıştır. $\mathrm{Bu}$ doğrultuda ortalamaların bağımlı değişken olduğu modele ilişkin eşitlikler aşağıdaki gibidir:

$$
\begin{gathered}
Y_{i j}=\beta_{0 j}+r_{i j} \\
\beta_{0 j}=\gamma_{00}+\gamma_{01} *\left(W 20 B_{j}\right)+\gamma_{02} *\left(W 18 A_{j}\right)+\gamma_{03} *\left(W 18 B_{j}\right)+\gamma_{04} *\left(W 14_{j}\right)+u_{0 j}
\end{gathered}
$$

*Bu değişkenler için genel ortalama merkezleme yapılmışıır

3) Rastgel-Katsayılar Regresyon Modeli (Random Coefficients): Üçüncü araştırma sorusunu yanıtlamak için kurulan bu modelde birinci düzeye fen puanlarıyla ilişkili öğrenci değişkenleri atanarak, hangi öğrenci düzeyi değişkeninin fen başarı puanına etki ettiği belirlenir. Modelde sınıf düzeyi değişkenleri yer almaz (Raudenbush \& Bryk, 2002). 2. Düzeye ait eşitlik ANOVA modelindeki ile aynıdır. Modelin 1. düzeyinde öğrenci değişkenlerine ait katsayılar, bağımsız değiş̧kendeki bir birimlik değişkenliğin okul ortalama başarı puanlarında meydana getirdiği değişiklik olarak yorumlanır. Modele ait eşitlikler aşağıdaki gibidir:

$$
\begin{gathered}
Y_{i j}=\beta_{0 j}+\beta_{1 j^{*}(} X 9_{i j)}+\beta_{2 j^{*}} X 10_{i j)}+\beta_{3 j^{*}} X 11 B_{i j)}+\beta_{4 j^{*}} X 11 C_{i j)}+r_{i j} \\
\beta_{0 j}=\gamma_{00}+u_{0 j} \\
\beta_{1 j}=\gamma_{10}+u_{1 j} \\
\beta_{2 j}=\gamma_{20}+u_{2 j} \\
\beta_{3 j}=\gamma_{30}+u_{3 j} \\
\beta_{4 j}=\gamma_{40}+u_{4 j}
\end{gathered}
$$

*Bu değişkenler için grup-otalama merkezleme yapılmıştır. 


\section{BULGULAR}

\section{Tek-Yönlü Varyans Analizi Rastgele Etkiler Modeline İlişkin Bulgular}

Analiz sonuçları Tablo 3 'te verilmiştir. Tablo incelendiğinde, genel fen başarı ortalaması için ağırlıklı en küçük kareler kestirimi 481.91 olup kestirimin standart hatası $3.98^{\prime}$ 'dir. Öğrenci genel fen başarı ortalaması için \%95 güven aralığı hesaplandığında [\%95CI $\left.\left(\gamma_{o o}\right)=\gamma_{00} \pm(1.96)(\mathrm{SH})\right]$, genel fen başarı ortalamasının gerçek değerinin \%95 olasılıkla 479.69 - 483.86 puan aralığında olduğu söylenebilir.

$\gamma_{\mathrm{oo}} \pm(1.96) *(\mathrm{SH})=481.91 \pm(1.96) *(3.91)=479.69-483.86$

Tablo 3. Tek-Yönlü Varyans Analizi Rastgele Etkiler Modeli Analiz Sonuçları

\begin{tabular}{|c|c|c|c|c|}
\hline Sabit Etki & Katsayı & $t$ & Standard Hata $(\mathrm{SH})$ & Yaklaşık $s d$ \\
\hline Genel fen başarı ortalaması, $\gamma_{00}$ & $481.91 *$ & 120.92 & 3.98 & 158 \\
\hline Rastgele Etki & Varyans & & Standart Sapma & \\
\hline Düzey-2 Hata Terimi, $u_{0 j}$ & 2983.99 & & $54.63^{*}$ & 240 \\
\hline Düzey-1 Hata Terimi, $r_{\mathrm{ij}}$ & 5498.73 & & 74.15 & \\
\hline
\end{tabular}

${ }^{*} p<.001$

Tablo 3'te ortalama fen başarı puanına ilişkin, sınıf içi değişkenliğin $\left(r_{\mathrm{ij}}\right) 5498.73$ ve sınıflar arası değişkenliğin $\left(u_{0 j}\right) 2983.99$ olarak kestirildiği görülmektedir. Sınıflar arası değişkenliğin tahmini değerinin $\left(u_{0 \mathrm{j}}\right)$ anlamlı olarak sıfirdan büyük bulunması $(p<.001)$ sınıfların ortalama fen başarıları arasında manidar farklılıklar olduğunu göstermektedir.

$\mathrm{Bu}$ model aracılığı ile ayrıca, fen puanları bakımından oluşan farklılığın ne kadarının öğrenci düzeyi ve ne kadarının sınıf düzeyi değişkenlerince açıklanabileceği hesaplanabilir. Tablo 3 'te yer alan okullar arası varyansın toplam varyansa bölünmesiyle fen başarı puanlarına ilişkin gruplar içi korelasyon katsayısı hesaplanmıştır (Raudenbush \& Bryk, 2002).

$$
\rho=\sigma^{2} /\left(\tau_{00}+\sigma^{2}\right)=5498.73 /(2983.99+5498.73)=0.65
$$

$\mathrm{Bu}$ sonuç, fen puanları bakımından oluşan farklılı̆̆ın \%65'lik kısmının öğrenciler arasındaki farklılıktan; \%35'inin ise sınıflar arasındaki ortalama fen başarısındaki farklılıktan kaynaklandığını göstermektedir. Farklı bir ifade ile öğrencilerin fen başarı puanlarındaki değişkenliğin büyük bir kısmı ögrenciler arasındaki farklılıklardan kaynaklanmaktadır.

\section{Ortalamaların Bağımlı Değişsen Olduğu Modele İlişkin Bulgular}

Bu modelde, [akademik başarıda okulun önemine ilişkin alg1 (W12), güvenli ve düzenli okul yapısına ilişkin alg1 (W13), okul imkan ve kaynakları ile ilgili problemler (W14), karşılaşılan güçlükler (W15), ögrenci ihtiyaçları ile sınırlı öğretim (W16), fen ödevlerine geri bildirim verme (W18A), fen ödevlerini sınıfta tartışma (W18B), araştırmaya verilen önem (W19), cevapların açıklanması (W20B), ilgi çekici materyal kullanımı (W20C), yeni içerik-önceki içerik bağlantısı (W20E), sınıf içi tartışmalar (W20F) ve problem çözme süreçlerine karar verme (W20G)] değişkenleri yer almıştır. Yapılan ilk analiz sonucunda etkileri manidar bulunmayan değişkenler modelden uzaklaştırılmıştır. Buna göre, W12, W16, W20C, W20F ve W20G fen başarı puanları ile ilişkileri olumlu yönde ancak manidar değildir. Benzer şekilde, W13, W15, W20E değişkenlerinin fen başarı puanları ile manidar olmayan negatif yönde ilişkileri bulunmuştur. Sonuçta yapılan son analize, W20B, W18A, W18B, W14 değişkenleri dahil edilmiştir. Nihai modele ilişkin eşitlik aşağıda verilmiştir:

$$
\beta_{0 j}=\gamma_{00}+\gamma_{01 *}\left(W 20 B_{j}\right)+\gamma_{02 *}\left(W 18 A_{j}\right)+\gamma_{03 *}\left(W 18 B_{j}\right)+\gamma_{04 *}\left(W 14_{j}\right)+u_{0 j}
$$

*genel ortalama merkezleme yapılmıştır.

$\mathrm{Bu}$ eşitlikte, $\gamma_{00}$, sınıfların düzeltilmiş genel fen başarı ortalamasıdır. $\gamma_{01}$, sınıfta verilen cevapların açıklanmasının; $\gamma_{02}$, ödevlere geri bildirim vermenin; $\gamma_{03}$, ödevleri sınıfta tartışmanın düzeltilmiş fen başarı ortalaması üzerindeki etkisi şeklinde yorumlanır. $u_{0 \mathrm{j}}$ (Düzey-2 hata terimi), modeldeki 
değişkenler kontrol altına alındığında j sınıfının fen başarı puanı ortalamasının genel fen başarı puanı ortalamasından farkı şeklinde ifade edilir.

Tablo 4. Ortalamaların Bağımlı Değişken Olduğu Model Analiz Sonuçları

\begin{tabular}{|c|c|c|c|c|c|}
\hline Sabit Etkiler & Katsayılar & Standard Hata & $t$ & $s d$ & Etki Büyük. \\
\hline Ortalama sınıf ortalaması, $\gamma 00$ Kesișim & 481.88 & 3.66 & 131.67 & 112 & \\
\hline $\mathrm{W} 20 \mathrm{~B}, \gamma_{01} *$ & -14.68 & 5.75 & -2.57 & 236 & -.30 \\
\hline $\mathrm{W} 18 \mathrm{~A}, \gamma_{02} *$ & 19.36 & 8.26 & 2.34 & 236 & .39 \\
\hline $\mathrm{W} 18 \mathrm{~B}, \gamma_{03} *$ & -14.74 & 6.90 & -2.13 & 236 & -.30 \\
\hline $\mathrm{W} 14, \gamma_{04} *$ & 9.91 & 1.50 & 6.57 & 236 & .20 \\
\hline Rastgele Etkiler & $\begin{array}{r}\text { Standart } \\
\text { Sapma }\end{array}$ & $\begin{array}{r}\text { Varyans } \\
\text { bileșenleri }\end{array}$ & $s d$ & $\chi^{2}$ & \\
\hline Düzey-2 Hata Terimi, $u_{0 j}$ & 48,816 & 2383.01 & 236 & 2982.37 & \\
\hline Düzey-1 Hata Terimi, $r_{\mathrm{ij}}$ & 74,154 & 5498.94 & & & \\
\hline
\end{tabular}

Tablo 4 incelendiğinde, modeldeki diğer değişkenler kontrol altına alındığında öğrencilerin verdikleri cevapları açıklamasının (W20B) fen başarı puanları üzerindeki etkisi negatif yönde manidar olarak kestirildiği $\left(\gamma_{01}=-14.68, t=-2.57, p<.001\right)$ görülmektedir. Bu doğrultuda, sinıf içerisindeki öğretim sürecinde cevapların sıklıkla açıklanması, okulların fen başarı puanlarını olumsuz yönde etkilemektedir. Bu okulların ortalama fen başarı puanı, cevapların daha az açıklandığı okullara göre yaklaşık 15 birim daha azdır. Benzer şekilde, modeldeki diğer değişkenler kontrol altına alındığında fen ödevlerini sınıfta tartışmanın (W18B), fen başarı puanlarına etkisi negatif yönde manidar olarak kestirilmiştir $\left(\gamma_{03}=-14.74, t=-2.13, p<.001\right)$. Buna göre, sınıf içerisinde fen ödevlerini sıklıkla tartışan öğrencilerin bulunduğu okulların fen başarı puanları, ödevlerin pek tartışılmadığı okulların fen başarı puanlarından 14.749 birim daha düşük olduğu görülmektedir.

Bu sonuçlardan farklı olarak, modeldeki diğer değişkenler kontrol altına alındığında fen ödevlerine geri bildirim vermenin (W18A), öğrencilerin fen başarı puanlarına etkisi pozitif yönde manidar kestirilmiştir $\left(\gamma_{02}=19.36, t=2.34, p<.001\right)$. Bu doğrultuda, sınıf içerisindeki öğretim sürecinde fen ödevlerine geri bildirim verilmesinin okulların fen başarı puanlarını olumlu yönde etkilediği görülmektedir. Fen başarı puanlarına pozitif yönde manidar etkisi bulunan bir diğer değişken okul imkân ve kaynakları ile ilgili problemlerdir (W14) $\left(\gamma_{04}=9.91, t=6.57, p<.001\right)$. Buna göre, modeldeki diğer değişkenler kontrol altına alındığında öğretmenlerin çalıştıkları okulların imkân ve kaynaklarındaki eksikliklerin öğretimi etkilemesine ilişkin algı düzeyleri arttıkça okulların fen başarısının bu durumdan olumlu yönde etkilendiği görülmektedir.

Analiz sonucunda elde edilen varyans oranları ve korelasyonel ilişkiler doğrultusunda yapılan yorumların, günlük hayata dair anlamlılık belirtip belirtmediği konusunda fikir vermesi adına etki büyüklüğü hesabı yapılmıştır. Bu doğrultuda, her bir düzeyde gerçekleştirilen analiz ile elde edilen sabit etki katsayılarının, ilgili düzeydeki artık değerin standart sapmasına bölünmesiyle etki büyüklüğü hesaplanmıştır. Etki büyüklüğü katsayısı, .41 minimum etkiyi gösterir (Ferguson, 2009). Hesaplanan etki büyüklüklerine bakıldığında bu değerlerin .41 'den aşağı düzeyde olduğu görülmektedir. Ancak büyük örneklemlerle gerçekleştirilen araştırmalarda .1 düzeyinde hesaplanan etki büyüklüklerinin dahi eğitim alanındaki gelişmelere katkısının olabileceği düşünüldüğünde (Glass, McGaw, \& Smith, 1981) bu değişkenlerin fen başarısı üzerinde pratikte hissedilebilecek düzeyde değişim meydana getirebileceği söylenebilir. Örneğin, modeldeki diğer değişkenler kontrol altına alındığında fen ödevlerine geri bildirim vermedeki bir standart sapmalık artışın fen başarı ortalamasında 0.39 standart sapmalık bir artış yaratması beklenir. Ödevleri sınıfta tartışıldığı okulların fen başarı puanları tartış1mayan okullara göre 0.30 standart sapma daha azdır denilebilir.

Son olarak, ANOVA modelinde fen başarı puanlarına ilişkin sınıflar arası varyans bileşeni olarak 2983.99 kestirilmişti. Modele sınıf düzeyinde değişkenlerin eklenmesiyle sınıflar arası varyans bileşeni olarak 2383.011 olarak kestirilmiştir. Dolayısıyla sınıf içi değişkenler, başarı puanlarına ilişkin gözlenen varyansın \%20'sini açıklamıştır [(2983.99-2383.011) /2983.99]. 


\section{Rastgele-Katsayılar Regresyon Modeline İlişkin Bulgular}

Bu modelede, cinsiyet (X8), devamsızlık yapmama (X9), kahvaltı yapmama (X10), evde teknoloji kullanımı (X11A), okulda teknoloji kullanımı (X11B) ve diğer yerlerde teknoloji kullanımı (X11C) değişkenleri yer almıştır. Yapılan ilk analiz sonucunda etkileri manidar bulunmayan değişkenler modelden uzaklaştırılmıştır. Buna göre X8'in fen başarısı ile pozitif yönde güçlü ilişkisi ve X11A'nın fen başarı puanı ile negatif yöndeki ilişkileri istatistiksel olarak manidar bulunmamıştır. Yapılan son analize, X9, X10, W11B, X11C değişkenleri dahil edilmiştir. Nihai modele ilişkin eşitlik aşağıda verilmiştir:

$$
Y_{i j}=\beta_{0 j}+\beta_{1 j *} X 9_{i j}+\beta_{2 j *} X 10_{i j}+\beta_{3 j^{*}} X 11 B_{i j}+\beta_{4 j *} X 11 C_{i j}+r_{i j}
$$

*grup ortalama merkezleme yapılmıştır.

Bu eşitlikte, $Y_{\mathrm{ij}}, j$ sınıfındaki $i$ öğrencisinin fen başarı puanını; $\beta_{0 \mathrm{j}}, j$ sınıfının ortalama fen başarı puanını göstermektedir. $\beta_{1 \mathrm{j}}, j$ sınıfında (modeldeki diğer değişkenler kontrol altına alındığında) devamsızlıktaki bir birimlik değişimin; $\beta_{2 j}, j$ sınıfında (modeldeki diğer değişkenler kontrol altına alındığında) beslenmedeki bir birimlik değişimin; $\beta_{3 j}, j$ sınıfında (modeldeki diğer değişkenler kontrol altına alındığında) teknoloji kullanımındaki bir birimlik değişimin; $\beta_{4 \mathrm{j}}, j$ sınıfında (modeldeki diğer değişkenler kontrol altına alındığında) diğer yerlerde teknoloji kullanımındaki bir birimlik değişimin sınıf ortalama fen başarı puanları üzerinde yarattı̆̆ı değişim şeklinde ifade edilir.

Tablo 5. Rastgele-Katsayılar Regresyon Modeli Analiz Sonuçları

\begin{tabular}{|c|c|c|c|c|}
\hline Sabit Etkiler & Katsayılar & Standart Hata & $t$ & Etki Büyüklüğü \\
\hline Kesim noktas1 $1, \beta_{0}$ Genel fen başarı ortalamas1, $\gamma_{00} *$ & 481.89 & 3.98 & 120.84 & -- \\
\hline X9 Eğim, $\beta_{1}$ Kesim noktas $2, \gamma_{10} *$ & 18.26 & 1.44 & 12.60 & 0.26 \\
\hline X10 Eğim, $\beta_{2}$ Kesim noktas1 $2, \gamma_{20} *$ & -2.90 & 1.13 & -2.55 & -0.00 \\
\hline X11B Eğim, $\beta_{3}$ Kesim noktas $2, \gamma_{30} *$ & 8.90 & 1.05 & 8.46 & 0.01 \\
\hline $\mathrm{X} 11 \mathrm{C}$ Eğim, $\beta_{4}$ Kesim noktas $2, \gamma_{40} *$ & -2.67 & 1.12 & -2.37 & -0.00 \\
\hline Rastgele Etkiler & $\begin{array}{r}\text { Standard } \\
\text { Hata } \\
\end{array}$ & $\begin{array}{r}\text { Varyans } \\
\text { bileşenleri }\end{array}$ & $s d$ & $X^{2}$ \\
\hline Düzey-2 Hata Terimi, $u_{0 j}$ & 54.83 & 3007.17 & 223 & $4003.17 *$ \\
\hline X9 Eğim, $u_{1}$ & 8.32 & 69.25 & 223 & 278.18 \\
\hline X10 Eğim, $u_{2}$ & 6.86 & 47.14 & 223 & 255.73 \\
\hline X11B Eğim, $u_{3}$ & 6.80 & 46.35 & 223 & 295.48 \\
\hline $\mathrm{X} 11 \mathrm{C}$ Eğim, $u_{4}$ & 6.06 & 36.83 & 223 & 254.55 \\
\hline Düzey-1 Hata Terimi, $r_{i j}$ & 69.93 & 4891.49 & & \\
\hline
\end{tabular}
${ }^{*} p<.001$

Tablo 5 incelendiğinde, fen puanları üzerinde en yüksek etkisi olan değişkenin devamsızlık yapmama (X9) olduğu görülmektedir. Modeldeki diğer değişkenler kontrol altına alındığında devamsızlığın fen başarı puanları üzerindeki etkisi pozitif yönde ve manidar olarak kestirilmiştir $\left(\gamma_{10}=18.26, \mathrm{SH}=1.44\right.$, $p<.001)$. Bu doğrultuda, neredeyse hiç devamsızlık yapmayan bir öğrencinin puanı, sık sık devamsızlık yapan bir öğrencinin fen puanından 18.27 birim daha fazladır yorumu yapılabilir. Okulda teknoloji kullanımı (X11B) fen başarı puanları üzerinde yüksek etkisi görülen bir diğer değişkendir. Katsayının $\left(\beta_{3}\right)$ istatistiksel olarak manidar olduğu görülmektedir $(p<.001)$. Modelde yer alan diğer değişkenler kontrol altına alındığında, okulda teknoloji kullanımında yaşanacak bir birimlik artışın (ölçekten alınan yüksek puanlar düşük kullanımı ifade etmektedir) öğrencilerin fen başarı puanlarında 8.90 birimlik bir artış meydana getireceği söylenebilir. Kahvaltı yapmamanın (X10) fen başarı puanları üzerindeki etkisi ise negatif yönde ve manidar olarak kestirilmiştir $\left(\gamma_{20}=-2.90, \mathrm{SH}=1.13, p<.001\right)$. $\mathrm{Bu}$ doğrultuda okula gittikleri günlerde neredeyse hiç kahvaltı yapmayan öğrencilerin ortalama fen başarısı her gün kahvaltı yapıp okula giden öğrencilere göre 2 birim daha azdır yorumu yapılabilir. Son olarak, modeldeki diğer değişkenler kontrol altına alındığında diğer yerlerde teknoloji kullanımı (X11C) nın fen puanları üzerindeki etkisi negatif yönde ve manidar olarak kestirilmiştir. Bundan yola çıkarak, modelde yer alan diğer değişkenler kontrol altına alındığında, teknolojiyi diğer yerlerde kullanım puanı (ölçekten alınan yüksek puanlar düşük kullanıma işaret etmektedir) arttıkça öğrencilerin fen başarı puanlarında 2.67 birimlik bir azalma söz konusu olacaktır denilebilir. 
Hesaplanan etki büyüklüklerine bakıldığında, okula devamsızlık yapmamadaki bir standart sapmalık artışın fen başarı ortalamasında 0.26 standart sapmalık; okulda teknolojiyi kullanmadaki bir standart sapmalık artışın fen başarı ortalamasında 0.01 standart sapmalık bir artış yaratacağı söylenir. Kahvaltı yapmamada oluşacak bir standart sapmalık artış fen başarı puanında 0.00 standart sapmalık bir azalma meydana getirecektir. Benzer şekilde, diğer yerlerde teknoloji kullanımında oluşan bir standart sapmalık artış fen başarısında 0.00 standart sapmalık bir azalma yaratacaktır.

Modele ilişkin varyans bileşenleri incelendiğinde, sınıf düzeyi bakımından varyansın rastgele etkisinini manidar olduğu belirlenmiştir $\left(\mathrm{X}^{2}=3007.17, \mathrm{sd}=223, p<.001\right)$. Ortalama fen puanları bakımından sınıflar arasında ortaya çıkan farklılaşma öğrenci düzeyi değişkenleri eklendiğinde seçkisizdir. Tablo 5'e göre, devamsızlık yapmama, kahvaltı yapmama, okulda teknoloji kullanımı ve diğer yerlerde teknoloji kullanımı değişkenlerinin eğimlerinin seçkisiz etkilerinin manidar olduğu belirlenmiştir $(p<.05)$. Bu durum, sınıfların ortalama fen puanlarının devamsızlık yapmama ve okulda teknoloji kullanımı değişkenleri ile ilişkilerinin sınıflar arasında istatistiksel olarak anlamlı bir şekilde değiştiğini ortaya koymaktadır.

Öğrenci düzeyindeki artık varyans (4891.49), ANOVA modelinde elde edilen varyanstan (5498.73) daha küçüktür. Bu bulgu, öğrenci düzeyi değişkenlerin eklenmesi ile fen başarı puanlarında öğrenciler arasında görülen farklılığın azaldığını göstermektedir. Öğrenci düzeyindeki değişkenler, başarı puanlarına ilişkin gözlenen varyansın \%11'lik kısmını açıklamıştır.

Örneklemden elde edilen değerlerin gerçek değerin güvenilir bir tahmincisi olup olmadığının anlaşılması için, 1. Düzey katsayılara ilişkin güvenirlik değerleri hesaplanmıştır. HLM analizi ile elde edilen sonuçlar aşağıda belirtilmiştir:

Tablo 6. 1. Düzey Tesadüfi Katsayılara İlişkin Güvenirlik Değerleri

\begin{tabular}{lr}
\hline 1. Düzey Tesadüfi Katsayılar & Güvenirlik Tahminleri \\
\hline Ortalama Fen Başarıs1, $\gamma_{00}$ & .93 \\
X9, $\gamma_{10}$ & .19 \\
$\mathrm{X} 10, \gamma_{20}$ & .16 \\
$\mathrm{X} 11 \mathrm{~B}, \gamma_{30}$ & .19 \\
$\mathrm{X} 11 \mathrm{C}, \gamma_{40}$ & .15 \\
\hline
\end{tabular}

Güvenirlik tahminleri 1. düzey katsayılarının tesadüfi, sabit veya tesadüfi olarak değişip değişmediği konusunda bilgi sağlar. 1. düzey katsayılarının güvenirliği .05'in altında ise bu katsayılar tesadüfi olarak değişmiyor ya da sabit olabilir (Acar, 2013; Raudenbush \& Bryk, 2002). Tablo 6'ya bakıldığında, sabite ait güvenirliğin yüksek bulunması (.93) örneklemden elde edilen fen ortalamasının, gerçek okul ortalamasının güvenilir bir tahmincisi olduğunu ifade etmektedir. Öğrenci düzeyinde bulunan açıklayıcı değişkenlerden devamsızlık, kahvaltı yapmama, okulda teknoloji kullanımı ve diğer yerlerde teknoloji kullanımına ait tahminlere bakıldığında bu değişkenlerin güvenirliklerinin çok yüksek bulunmadığı görülmektedir. Ancak, düşük düzeyde de olsa bu değişkenlerin fen başarısının güvenilir birer tahmincisi olduğu söylenebilir. Ayrıca, bu değişkenlerin güvenirlik tahminlerinin .05 'ten büyük olması, bu katsayıların okullara karşı tesadüfi olarak değiştiğini göstermektedir.

\section{SONUÇLAR ve TARTIŞMA}

$\mathrm{Bu}$ araştırmada 4. sınıf öğrencilerinin geniş ölçekli bir uygulamada elde edilen fen başarılarına etki ettiği düşünülen öğrenci ve sınıf kaynaklı faktörler birlikte ele alınmıştır. Dolayısıyla, araştırma eğitim sistemleri açısından önemli bir yere sahip olan geniş ölçekli değerlendirme literatürüne katkıda bulunması açısından önemlidir. Yapılan HLM analizi neticesinde, sınıf düzeyinde, öğrencilerin verdikleri cevapları açıklaması, fen ödevlerine geri bildirim verme, fen ödevlerini sınıfta tartışma ve okul imkân ve kaynakları ile ilgili problemler konusunda öğretmenlerin algısının fen başarı ortalamalarına istatistiksel olarak manidar etkili olduğu görülmüş̧ür. Buna karşılık, akademik başarıda okulun önemine ilişkin öğretmenlerin algısı, öğrenci ihtiyaçları ile sınırlanan öğretim, ilgi çekici 
materyal kullanımı, sınıf içi tartışmalar, problem çözme süreçlerine karar verme, güvenli ve düzenli okul yapısına ilişkin öğretmenlerin algısı, öğretmenlerin karşılaştıkları güçlükler, yeni içerik-önceki bağlantısının fen başarı ortalamalarına etkileri manidar bulunmamıştır. Öğrenci düzeyinde, ögrencilerin cinsiyeti ve evde teknoloji kullanımlarının fen başarı ortalamalarına etkileri istatistiksel olarak manidar değildir. Ancak, kahvaltı yapmama, devamsızlık yapmama, okulda teknoloji kullanımı, okul ve ev dışında diğer yerlerde teknoloji kullanımı fen başarı ortalamalarına manidar etkili bulunmuştur. Şekil 1, araştırmanın bulgularından yola çıkarak 4. sınıf TIMSS fen başarısının öğrenci ve sınıf düzeyindeki belirleyicilerine ilişkin düzenlenmiştir.

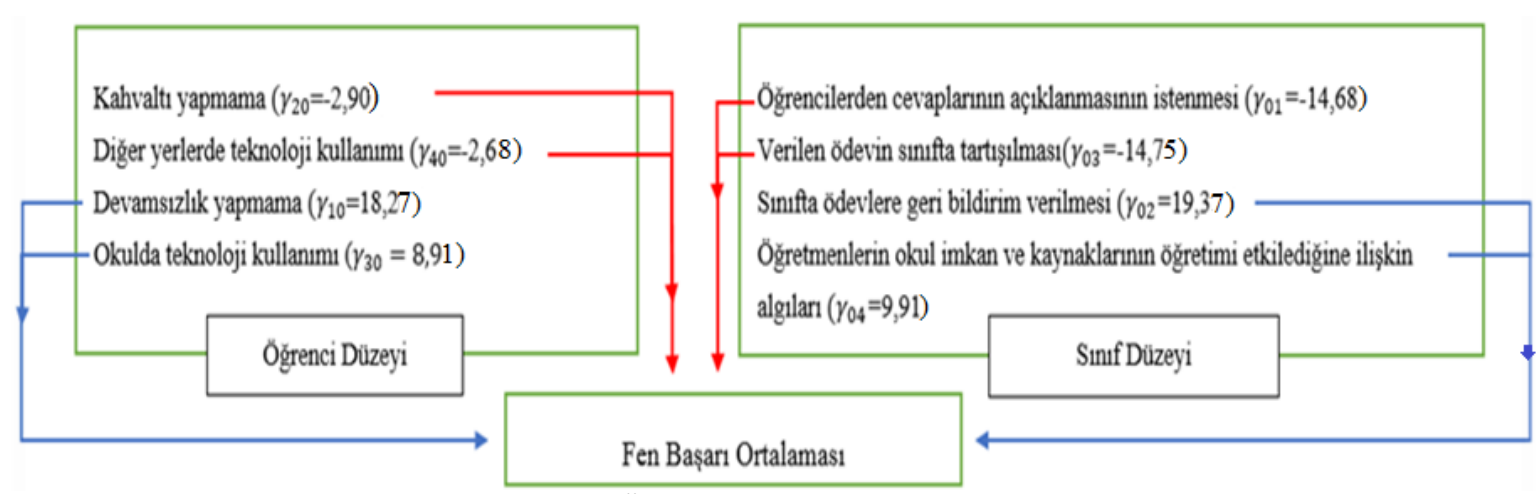

Şekil 1. 4. Sınıf TIMSS Fen Başarısının Öğrenci ve Sınıf Düzeylerindeki Belirleyicileri

Araştırmada, öğrencilerin fen başarı puanlarındaki farklılıkların \%65'lik kısmının öğrenciler arasındaki farklılıktan; \%35'inin ise sınıflar arası farklılıktan kaynaklandığı bulunmuştur. Dolayısıyla, başarıdaki değişkenliğin büyük bir kısmı öğrenciler arasındaki farklılıklardan kaynaklanmaktadır. Bu konuda yapılan meta-analiz çalışmaları (Hattie, 2009; Sirin, 2005), öğrenci başarılarında okullar arası farklılıklara ilişkin yapılan kestirimlerin ikiye ayrıldığını göstermektedir. Bir kısım araştırmalarda öğrenci başarılarındaki farklılıkların büyük bir kısmının okul düzeyi tarafından açıklandığı belirtilmektedir (İpekçioğlu-Önal, 2015; Mohammadpour \& Abdul Ghafar, 2014; Özgen, 2009; Yılmaz \& Aztekin, 2012). Diğer bazı araştırmaların sonuçları ise, mevcut çalışmanın sonuçlarında olduğu gibi öğrenci başarılarında görülen farklılıkların kaynağının büyük bir kısmının öğrenci düzeyi tarafından açıklandığına ilişkin bulguları desteklemektedir (Akyüz \& Berberoğlu, 2010; Akyüz-Aru \& Kale, 2019; Atar \& Atar, 2012; Aydın, 2015; İpekçioğlu-Önal, 2015; Ryoo, 2001; Sevgi, 2009).

Fen başarılarına ilişkin okullar arası varyansın açıklanmasında sınıf düzeyindeki değişkenlerin katkısı önemli bulunmuştur. Öğrencilerin derslerde verdikleri cevapları açıklaması, fen ödevlerine geri bildirim verme, fen ödevlerini sınıfta tartışma, okul imkân ve kaynakları ile ilgili problemler konusunda öğretmenlerin algısı, başarı puanlarına ilişsin gözlenen varyansın yaklaşık \%20'sini açıklamıştır. Wenglinsky (2000), sınıf içi süreçlere ilişkin değişkenlerin öğrenci başarıları üzerindeki belirleyiciliğinin araştırılmasının önemli olduğunu, ailenin veya öğrenci özelliklerinin başarı üzerindeki etkisinde olduğu gibi anlamlı düzeylerde etkilerini gösteren sonuçlar elde edilebileceğini ancak literatürde sınıf içi süreçlerin başarıya etkilerinin araştırılmasının genellikle göz ardı edildiğini belirtmektedir. Varyansın ilgili düzeyde açıklama oranının büyüklüğüne bakıldığında sonuçlar Wenglinsky'ın (2000) iddiasını doğrular niteliktedir.

Çalışmada kullanılan değişkenler arasında etki büyüklüklerine de bakıldığında, sınıf düzeyinde okulların ortalama fen başarısı üzerinde en büyük etkiye sahip değişken verilen fen ödevlerine geri bildirim vermedir. Öğrencilerin sınıf içerisindeki psikolojik ihtiyaçlarının karşılanarak destekleyici bir atmosferin oluşturulduğu sınıfların en belirgin özellikleri başarı ölçümlerinin devamlı yükselmesidir. $\mathrm{Bu}$ sinıflarda genellikle öğretmenlerin, öğrencilerine olumlu geri bildirimler verme ve empati kurma konusunda istekli olduğu; onlara rehberlik ederek, öğrencilerin özerk çalışmalarını sağlayacak ortamlar yarattığı bilinmektedir (Ryan \& Deci, 2000). Dolayısıyla sınıf içinde ödevlere geri bildirim verilmesi öğrencileri zihinsel ve psikolojik açıdan rahatlatan bir faktör olabilir. Öğrenci, ödeve ilişkin dönüt ile varsa eksik ve yanlışlarını görebilir, farklı çözüm yolları öğrenir, süreç sonunda öğretmen ile 
görüşebileceğini bilerek rahatlayabilir. Gayretinin karşıllı̆ı olarak öğretmen tarafından takdir edilmesi de psikolojik bir destek olarak düşünülürse başarıyı olumlu yönde etkileyeceği söylenebilir. Sınıf içerisinde ödev uygulamalarına yönelik bir araştırmada Zhu ve Leung (2012), ödevlere ayrılan sürenin başarı ile anlamlı ilişkiler gösterdiğini belirtmiştir. Ayrılan bu sürenin nasıl geçirildiği ise önemlidir. Akyüz (2006), ödevlere vurgu yapmanın ve ödevleri kontrol etmenin öğrenci başarılarına pozitif etkisi olduğunu ortaya koymuştur. Dolayısıyla, öğretmenlerin ödevler konusunda yapacakları planlamada geri bildirimin önemi ortaya çıkmaktadır.

Ödevlerin sınıfta tartışılmasının başarı üzerinde negatif manidar etkisinin görülmesi ise ilginçtir. Sonuçlara göre, sınıf içerisinde fen ödevlerini sıklıkla tartışan öğrencilerin bulunduğu okulların fen başarı puanları, ödevlerin pek tartışılmadığı okulların fen başarı puanlarından daha düşük bulunmuştur. Ödevlerin sınıfta tartışılması konusu ödevlere geribildirim verilmesi ile bir arada değerlendirilebilir. Günümüzde ödevlerin sınıf içerisinde ve sınıflar arasında yaş ve başarı fark1 gözetmeksizin öğretmenler tarafından hala sıklıkla kullanılan bir öğrenme aracı olduğu bilinmektedir (Trautwein, 2007; Won \& Han, 2010). Ancak, ödevlerin sınıf içindeki kullanımı bazı durumlarda başarıya olumsuz etki edebilmektedir. Bu konu, öğrencinin psikolojisi açısından değerlendirilebilir. Öğrenciye ödev konusunda geribildirim verme hususu öğretmenin daha aktif ve öğrencinin edilgen olduğu bir süreç olarak değerlendirildiğinde, verilen ödeve ilişkin sınıftaki tartışmalar öğrencinin daha aktif olmasını zorunlu kılar. Tartışma öğrencinin ödevi yapma şekli, düşünce tarzı, ödeve yaklaşımı ve özellikle de yanlışlar üzerinde olabilir. Bu durumda öğretmenin tepkileri ve süreci yönlendirme şekli çok önemlidir. Ryan ve Deci (2000), öğretmenlerin öğrencilerine olumlu geri bildirim vermenin ve onlarla empati kurmanın öğrencilerin sınıf içerisindeki psikolojik ihtiyaçlarının karşılanarak destekleyici bir sınıf iklimi oluşturulmasında önemli olduğunu belirtmektedir. 4. sınıfa giden 9-10 yaşındaki bir öğrencinin psikolojisi yanlışların sınıfta tartışılmasını farklı algılamaya yatkın olabilir ve dolayısıyla başarının ödevlerin tartışılması ile olan negatif etkileşimi bu çerçevede değerlendirilebilir.

Fen dersleri, doğası gereği öğrencinin meraklanmasını, sorgulamasını, cevaplar aramasını, kendine güvenerek öğrenmenin sorumluluğunu üstlenmesini gerektiren süreçlerdir. Dolayısıyla bu derslere öğrenciler için problemler, ikilemler ve sorularla başlamak uygun olur (Hiebert ve diğerleri, 1997). van de Valle, Karp ve Bay-Williams (2010), gerekçelendirmenin fen derslerinin temel bir parçası olması gerektiğini belirtmektedir. Bu noktada, öğretmenlere önemli görevler düşmektedir. Öğretmenlerin kullanacakları dil ve ifade öğrencilerin fikirlerini istekli bir biçimde açıklamaları konusunda önemli bir belirleyici olacaktır. Araştırmanın sonuçları göstermiştir ki, öğrenciler sınıf içinde yanıtlarını açıklamaya yönlendirildikçe fen dersinde daha başarısız olmuştur. Dolayısıyla bu sonuçlar, öğretmenlerin kullandıkları dil açısından değerlendirilebilir.

Deci ve Ryan (1985), öğrencilerin derslik içinde etkileşim gibi bir takım psikolojik ihtiyaçlarının karşılanmasında öğretmenin büyük rol oynadığını vurgular. Öğretmenler öğrencilerin bu psikolojik ihtiyaçlarını karşılamak için çaba sarf ettiklerini bildirseler de öğrencilerin bu çabalara yönelik algıları daha önemlidir (Daniels \& Perry, 2003). Nitekim araştırmanın sınıf düzeyindeki sonuçları bu algıların önemini vurgular niteliktedir. Bu konuda belirtilen literatürden de yola çıkarak denilebilir ki, yanıtların açıklanması yönünde destek olmada öğretmenlerin ortaya koyduğu tutum, öğrencilerin özellikle sınıfta verdikleri yanıtları açıklamak konusunda psikolojik olarak endişe duymalarına veya moral bozukluğu yaşamalarına sebebiyet veriyor olabilir. Dolayısıyla performans bu süreçten olumsuz etkilenmektedir.

Araştırmanın okul kaynakları konusundaki bulgusu, öğretmenlerin çalıştıkları okulların imkân ve kaynaklarındaki eksikliklerin öğretimi etkilemesine ilişkin algı düzeyleri arttıkça okulların fen başarısının bu durumdan olumlu yönde etkilendiği yönündedir. Bu sonuç da ilginç olmakla birlikte psikolojik açıdan değerlendirilebilir. Öğretmenlerin çalışma koşullarını iyi olduğu ortamlarda kendilerini daha mutlu hissettiği (Hooper ve diğerleri, 2013; World Bank, 2011) gerçeğinden yola çıkarak, kaynak sıkıntısı koşullar içerisinde değerlendirildiğinde, bu durumun öğrenci başarısını direkt olarak olmasa da öğretmenlerin algılarında meydana getirdiği olumsuzluklardan ötürü dolaylı bir şekilde etkilediği söylenebilir. Öğretmenlerin yönetimden kaynaklanan bazı sorunları görüp daha da büyüttüğü ve sınıf başarısını olumsuz yönde etkileyecek şekilde içselleştirdiği durumlar görülebildiği gibi bundan öğretmenlerin pek etkilenmediğini gösteren araştırmalar da (Bénabou, Kramarz, \& Prost, 2009; Wößmann, 2003) mevcuttur. Ancak, çalışmanın sonuçlarına göre öğretmenlerin kaynak 
sıkıntısının bir problem olarak görseler de bunu öğretim sürecine yansıtmadıkları ve bunu özel çabalarıyla çözdükleri yorumu yapılabilir. Böyle durumlarda, öğretmenlerin öğrencileri ile iş birliği yaparak eldeki imkanlarla kaynak sıkıntılarını aştıkları görülebilmektedir.

Araştırmanın öğrenci düzeyindeki sonuçlarına bakıldığında, devamsızlık başarı puanlarında görülen varyansı açıklamaya en yüksek düzeyde katkı sağlayan değişken olmuştur. Devamsızlık konusunda, mevcut çalışmanın sonuçlarıyla paralel çalışmalar bulunmaktadır. Alexander ve Hicks (2015) çalışmalarında, 383 öğrencinin devamsızlık durumları ile başarı puanları arasında anlamlı ve pozitif bir ilişki olduğunu bulmuştur. Çalışmanın sonuçlarına göre, derse düzenli bir şekilde devam eden öğrencilerin akademik performansları devamsız öğrencilere göre daha yüksektir. Benzer şekilde Khalid'in (2017), 119 katılımcıyla gerçekleştirdiği çalışmasının sonuçlarına göre devamsızlık, öğrencilerin notlarını olumsuz yönde etkilemektedir. Devamsızlık, özellikle öğrencilerin psikolojik arka planını da içine alan, farklı bileşenlerden oluşan önemli bir konudur. Yapılan araştırmalar, genellikle "kronik devamsızlık" üzerinde yoğunlaşmaktadır ve sonuçlar öğrencilerin devamsızlık oranları arttıkça başarının manidar bir şekilde azaldığını göstermektedir. Ancak, Cattan, Kamhöfer, Karlsson ve Nilsson (2017, s. 47), "bu konuda literatürdeki çalışmaların yetersiz olduğunu" belirtmektedir.

Bir diğer sonuç, okula kahvaltı yapmadan gelen öğrencilerin bu durumunun onların akademik performanslarını olumsuz etkilediği yönündedir. Literatürde, beslenme ve akademik başarı arasında pozitif ancak düşük düzeyde bir ilişki olduğundan söz eden çalışmalar (Dwyer, Sallis, Blizzard, Lazarus, \& Dean, 2001; Keeley \& Fox, 2009) bulunmaktadır. Shaw, Gomes, Polotskaia ve Jankowska (2015), yapmış oldukları çalışmada öğrenci sağlı̆̆ının kontrol edilebilir yönlerinin beslenme, sağlıklı kilonun korunması ve akranları ile fiziksel denklik olduğunu belirtmektedir. Sağlığ yetersiz olan ögrencilerde, okul başarısızlığı, sınıfta kalma ve okuldan ayrılma olasılı̆̆ının daha yüksek olduğunu göstermektedir. Kolasa ve diğerleri (2018), yurt dışında beslenme ve akademik başarı konusunda gerçekleştirilen pek çok çalışmanın okullarda verilen beslenme programları ekseninde gerçekleştirildiğini belirtmektedir. 4. sınıf müfredatına gıda /beslenme eğitimini entegre etmenin akademik bilgi kazanımlarını destekleyebileceğine dair kanıt sağlamak için gerçekleştirilen çalışmaların ortak sonucu, fen ve matematik bilgisinin, akademik bilgiyi geliştirmek için bütüncül bir şekilde beslenme bilgisi ile örtüşür olduğu ve fen ve matematik müfredatı kullanılarak dördüncü sınıf öğrencileri arasında beslenme bilgisinin de aynı anda geliştirebileceği yönündedir (Kolasa ve diğerleri, 2018).

Türkiye'de ilkokul müfredatında beslenme için özel bir ders bulunmamaktadır. Hayat bilgisi derslerinde, düzenli ve dengeli beslenmeye yönelik metinler yer almaktadır. Ayrıca ilkokul fen bilimleri müfredatının bir ünitesinde besinlerin içerikleri ve dengeli beslenme üzerinde kısaca durulmaktadır. Bu noktada, ilkokul müfredatına beslenmeye ilişkin zorunlu veya seçmeli beslenme dersi koyulabilir. $\mathrm{Bu}$ dersin içeriği, öğrencilerin ihtiyaçları tespit edildikten sonra aileler de dahil edilerek belirlenebilir ya da beslenme atölyeleri düzenlenebilir. Bu atölyede dersler, uygulamalı olarak, aileler ve öğrencilerin katılımı ile gerçekleştirilebilir.

Okulda ve diğer yerlerde teknoloji kullanımı, fen başarı puanları üzerinde yüksek etkisi görülen bir diğer değişkendir. TIMSS öğrenci anketinde yer alan teknoloji kullanımı (bilgisayar, tablet, vb.) ölçeğinden alınan düşük puanlar teknolojinin daha sıklıkla kullanıldığı anlamına gelmektedir. Dolayısıyla, fen başarısı daha yüksek olan öğrenciler, ödev amacıyla okulda daha seyrek ancak okul dışında daha sık teknoloji kullandıklarını belirtmiştir. Öğrencilerin okulda teknolojiye erişimi ile okul ve ev dışında farklı yerlerde teknolojiye erişimi süre açısından değerlendirildiğinde farklılık gösterebilir. Okul dışında, daha uzun süreler ödev vb. için internet karşısında zaman geçirilebilir. Ayrıca, sonuçlardan yola çıkarak, öğrencilerin teknolojiyi okul dışında ödev amaçlı verimli bir şekilde kullandığ 1 yorumu da yapılabilir. TIMSS 2015'in sonuçlarına göre, öğrencilerin \%33'ünün fen derslerinde bilgisayar kullanımına izin verilmektedir (Martin, Mullis, Foy ve diğerleri, 2016). Türkiye açısından düşünüldüğünde okulda ders sırasında internet kullanımının bilişim derslerin haricinde sınırlı olduğu bilinmektedir. Dolayısıyla öğrenciler ödevleri için okul dışındaki teknoloji kaynaklarına yönelebilmektedir. Okul dışında internetin ne amaçla kullanıldığı TIMSS uygulamasına katılan 8. sınıf ögrencilerine sorulmuştur. Öğrencilerin çoğunluğu (\%75), okul dışında interneti büyük bir oranda 
arkadaşları ile proje ödevlerini hazırlamak için kullandığını belirtmiştir (Martin, Mullis, Foy ve diğerleri, 2016). Sonuç olarak, okulda imkanlar tanınırsa öğrenciler teknolojiden ödev ve araştırma amaçlı faydalanabilirler.

Son yıllarda, bu yönde çalışmalar hız kazanmıştır. Teknolojinin eğitim öğretim ortamlarına entegre olması ile, farklı içeriklerle hazırlanmış; pek çok ilgi çekici görseli ve anlatımı barındıran programların da derslerde öğretmenler tarafından bizzat kullanılması ve öğrencilerin de bu programlara interaktif katılımı artık sıklıkla gözlenen bir durumdur. Fen dersinin doğası düşünüldüğünde, özellikle okullarda öğretmenlerin gözetiminde bilgisayar kullanımının öğrencilerin başarılarına olumlu yönde etki edeceği rahatlıkla tahmin edilebilir. Türkiye'nin 2023 Eğitim Vizyonu çerçevesinde, teknolojinin eğitim öğretime entegrasyonunun sağlanması konusunun vurgulandığı görülmektedir. İçinde bulunduğumuz salgın döneminde, Türkiye teknolojinin eğitime entegrasyonunun başarılı bir örneğini öğrenci-öğretmen-veli-okul kaynaklarının birbirleri ile etkileşiminde göstermektedir. Uzaktan eğitim sürecinde, pek çok öğretmen ve öğrenci teknoloji ile bir sınav vermektedir. Süreç sonlandığında belki en büyük kazanım, teknolojinin eğitim-öğretim için yararlı ve kaçınılmaz bir unsur olduğunun keşfedilmesi olabilir.

\section{Öneriler}

$\mathrm{Bu}$ araştırmanın öğrenci başarısıyla ilişkili olarak öğrenci ve sınıf düzeyindeki değişkenleri, TIMSS 2015 çalışmasında öğrenci anketi ve öğretmen anketinde yer alan ve bu düzeydeki özellikleri ölçen maddeleri ile sınırlıdır. Ayrıca bir nedensel karşılaştırma çalışmasıdır. Sonuç değişkeni TIMSS uygulamasında ölçüldüğü şekilde fen başarı puanlarıdır. Örneklemini sadece TIMSS 2015'e katılmış belirli sayıdaki öğrenci ve öğretmen grubu oluşturmaktadır. Gelecek araştırmalarda, deneysel yöntemin tercih edilmesi sonuçlar ile ilgili daha detaylı tartışmaların yapılmasına olanak sağlayacaktır. Ayrıca, farklı değişkenler ve daha farklı gruplar ile araştırmalar gerçekleştirilebilir. HLM'de kesişim ve eğim modeli ile farklı düzeylerde yer alan değişkenlerin birbirleri ile olan ilişkilerinin başarı ile olan çapraz düzey etkileşimlerine bakılabilir.

Araştırmanın teknolojinin kullanımına ilişkin bulguları, okulda teknoloji kullanımının öğrencilerin fen performanslarını olumlu yönde etkilerken; okul dışında diğer yerlerde teknoloji kullanımının öğrencilerin fen başarı puanlarına negatif yönde manidar düzeyde etki ettiğini göstermiştir. Bu bulgular 1şığında, Millî Eğitim Bakanlığı ve eğitimle ilgilenen benzer kuruluşlarca, özellikle ilkokul çağındaki öğrencilerin teknolojiyi evde ve diğer yerlerde kullanımlarına ilişkin öğrenciler, ebeveynler ve öğretmenlere yönelik teknolojinin bilinçli kullanımı konusunda eğitimler düzenlenmesi önerilebilir. İnternetin öğrencilerin sosyal ve akademik gelişimlerini zedelemeden faydalı bir yönde kullanımını amaçlayan uygulamalı faaliyetler gerçekleştirilebilir. Bu faaliyetler özellikle küçük yaştaki ilkokul öğrencilerinin günlük tablet, bilgisayar, telefon vb. kullanım sürelerinin sınıf öğretmenlerince takip edilmesi ile başlatılabilir. Sonrasında ne tür içeriklerin tercih edildiği tespit edilmelidir. Süreç, akademik ve kişisel gelişim konusunda faydalı içerikler ve teknolojinin doğru yöne kanalize edilmesi konusunda yönlendirmeler ile devam edebilir. $\mathrm{Bu}$ konuda gerçekleştirilecek faaliyetler, sınıf öğretmenleri tarafından yönetilmelidir.

Araştırmanın bulgularına göre, devamsızlık, öğrenci düzeyinde fen başarı puanlarına en yüksek düzeyde etki eden değişken olmuştur. Devamsızlık, fen başarı puanlarına negatif düzeyde etki etmektedir. Ayrıca, PISA ve TIMSS 2015 verilerine göre, Türk öğrenciler katılımcı diğer ülkelerin ögrencilerine kıyasla daha sık devamsızlık yapmaktadır. Bu bulgular doğrultusunda, özellikle alışkanlık haline getirilmiş devamsızlıklar (kronik devamsızlık) konusunda okullarda gerçekleştirilmek üzere devamsızlı̆̆ı araştırma projesi önerilebilir. Proje kapsamında, her bir okulun devamsızlı araştırmacısı ilgili İlçe Milli Eğitim Müdürlüğ̈̈ tarafindan okulda görev yapan öğretmenler içerisinden atanabilir. Araştırmacı olarak görevlendirilecek olan öğretmenler, devamsızlık konusunda literatürde yapılmış son akademik çalışmaların bulgularının da konu edildiği seminerleri almalıdır. Sonraki süreçte, bu öğretmenler belirlenecek periyotlarda İlçe Müdürlüklerine raporlar sunarlar. Rapor içerikleri okul bazında devamsız öğrenciler, devamsızlık nedenleri, yapılan görüşmeler vb. olabilir. Buna ek olarak araştırmacı öğretmen, devam konusunda sorun yaşamayan 
öğrenci ve okulları da tespit ederek gözlemler. Devamsızlık sorunu olan okullarda devamın arttırılmasına dönük bir yaklaşım konusunda bu gözlemin sonuçlarından faydalanılabilir.

Çalışmanın bir diğer bulgusu, beslenmeye ilişkindir. Okula kahvaltı yapmadan gelme, fen puanlarına negatif yönde ve manidar düzeyde etki etmiştir. Bu bulgular ışı̆̆ında, ilkokul müfredatına beslenmeye ilişkin zorunlu veya seçmeli beslenme dersinin dahil edilmesi önerilebilir. $\mathrm{Bu}$ dersin içeriği, ögrencilerin ihtiyaçları tespit edildikten sonra belirlenmelidir. Beslenme dersine aileler de dahil edilebilir. Seçmeli bir ders okul çıkışına bir ders saati eklenerek gerçekleştirilebilir. Veya beslenme atölyeleri düzenlenebilir. Bu atölyede dersler, uygulamalı olarak aileler ve öğrencilerin katılımı ile gerçekleştirilebilir. Beslenme sorunları, sağlı ve beslenme ilişkisi, akademik başarı ve beslenme, düzenli ve dengeli beslenme, günlük yaşamdan iyi örnekler vb. konularda etkinlikler ile beslenme dersi zenginleştirilebilir.

Beslenme konusundaki öneriler, öğrencilerin beslenme teneffüsleri konusunda da geliştirilebilir. Nitekim, bu teneffüslerde öğrenciler beslenme getirerek karınlarını doyurmaktadır. Bu teneffüslerin nasıl geçirildiği, ne kadar sürdüğü, öğrencilerin neler tükettiği, varsa beslenme listelerinin nasıl hazırlandığı konuları araştırılmalıdır. Bu doğrultuda İlçe Milli Eğitim Müdürlükleri bünyesinde gıda mühendisleri görevlendirilebilir. Okul bazında bir sorumlu belirlenerek, belirli periyotlarla gıda mühendisi ile görüşme günleri ayarlanabilir. Bu görüşmelerde, öğrencilerin beslenme alışkanlıklarına yönelik yararlı diyaloglar kurulmalıdır.

Araştırmanın sınıf düzeyindeki bulguları, okulların ortalama fen başarısı üzerinde en büyük etkiye sahip değişkenin verilen fen ödevlerine geri bildirim verme olduğunu göstermektedir. Ayrıca, ödevlerin sınıfta tartışılması başarı üzerinde negatif manidar etkilidir. Sonuçlara göre, sınıf içerisinde fen ödevlerini sıklıkla tartışan öğrencilerin bulunduğu okulların fen başarı puanları, ödevlerin pek tartışılmadığı okulların fen başarı puanlarından daha düşük bulunmuştur. Sınıf düzeyindeki sonuçlar, ögretmenlerin ödevler konusunda öğrencilere olan tutumlarını ön plana çıkarmıştır. Tutum, duyuşsal bir faktör olarak değerlendirildiğinde denilebilir ki, ödevlerin, ilkokul öğrencilerinin akademik performanslarını etkileyen aslında psikolojik bir yapısı da bulunmaktadır. Bu bulgular 1şığında düşünüldüğünde ödevler konusunun hassasiyeti ortaya çıkmaktadır. Bu doğrultuda öğretim sürecinde ödevlerin kullanımı ve öğretmenlerin bu esnadaki tutumlarını inceleyen çalışmalar sürece katk1 sunabilir. Ödevler konusunda ilgili kurumlarca öğretmenlerin ödev sürecini nasıl yönettiğine yönelik saha çalışmaları gerçekleştirilebilir. Sonuçlara göre öğretmenlere eğitimler verilmeli ve bu konuda gelişimleri desteklenmelidir.

Türkiye'de ilkokul çağında öğrencisi bulunan ailelerin ve henüz 1. sınıfa başlayacak olan öğrencilerin ebeveynlerinin okul konusunda yaşadığı problemlerden birisi ödevlerdir ve bu konuda velilerin ön yargısı olabilmektedir. Dolayısıyla, sene başında aile ile okula taşınan bu önyargı kırılmaz ise büyüyerek ilkokulun diğer yıllarına yayılabilmekte ve bu durum öğrencinin ödev konusundaki algısını olumsuz yönde etkileyebilmektedir. Bu konuda eğitimcilere ve özellikle ilkokul öğretmenlerine büyük görevler düşmektedir. 1. sınıfta verilecek ev ödevleri titizlikle ve öğrencilerin gelişimsel süreçlerine, psikolojilerine ve ihtiyaçlarına uygun olarak düşünülmelidir. Ödevler amacının tam aksine çocuk ve aile için bir işkence olmamalıdır. Dolayısıyla, ebeveynler ile gerçekleştirilecek çalışmalar da önem arz etmektedir. Bu doğrultuda, okullarda interaktif ödev portalları oluşturulması önerilebilir. Çocukların dijital medyaya olan ilgileri bu konuda güzel bir fırsat olabilir. Böylelikle, ailelerin ödevlere ilişkin vereceği tepkiler de anlık değerlendirilebilir. Bu süreçte öğretmen izleyici ve bir katılımcı olarak ödevler konusunda yapıcı geri bildirimler ile aileyi rahatlatabilir.

\section{KAYNAKÇA}

Acar, M. (2013). Öğrenci başarılarının belirlenmesi sınavında Türkçe dersi başarısının öğrenci ve okul özellikleri ile ilişkisinin hiyerarşik lineer model ile analizi (Doktora tezi). Ankara Üniversitesi Eğitim Bilimleri Enstitüsü, Ankara.

Ackerman, P. L. (2013). Engagement and opportunity to learn. In J. Hattie, \& E. M. Anderman (Eds.), The international guide to student achievement (pp. 39-41). New York: Taylor \& Francis.

Akey, T., M. (2006). School context, student attitudes and behavior, and academic achievement: An exploratory analysis. New York: MDRC. Retrieved from https://files.eric.ed.gov/fulltext/ED489760.pdf 
Akkuş, M. (2014). PISA, TIMSS ve PIRLS sonuçlarının değerlendirilmesi (Yüksek lisans tezi). İstanbul Aydın Üniversitesi, Sosyal Bilimler Enstitüsü, İstanbul.

Aktaş, I. (2011). TIMSS 2007 verilerine göre öğrenci fen başarısı ile ögrretmenlerinin özellikleri arasındaki ilişkinin incelenmesi (Yüksek lisans tezi). Hacettepe Üniversitesi, Ankara.

Akyüz-Aru, S., \& Kale, M. (2019). Effects of school-related factors and early learning experiences on mathematics achievement: A multilevel analysis to analyze the TIMSS data. Journal of Education and Training Studies, 7(4), 259-272. doi: 10.11114/jets.v7i4.3949

Akyüz, G. (2006). Türkiye ve Avrupa Birliği ülkelerinde öğretmen ve sınıf niteliklerinin matematik başarısına etkisinin incelenmesi. Illkögretim Online, 5(2), 75-86. http://ilkogretim-online.org//?mno=121113 adresinden erişilmiştir.

Akyüz, G., ve Berberoğlu, G. (2010). Teacher and classroom characteristics and their relations to mathematics achievement of the students in the TIMSS. New Horizons in Education, 58(1),77-95. Retrieved from https://www.researchgate.net/publication/293232168_Teacher_and_classroom_characteristics_and_the ir_relations_to_mathematics_achievement_of_the_students_in_the_TIMSS

Alexander, V., \& Hicks, R. E. (2015). Does class attendance predict academic performance in first year psychology tutorials? International Journal of Psychological Studies, 8(1), 28-32. doi: 10.5539/ijps.v8n1p28

Asigbee, F. M., Whitney, S. D., \& Peterson, C. E. (2018). The link between nutrition and physical activity in increasing academic achievement. Journal of School Health, 88(6), 407-415. doi: 10.1111/josh.12625

Atar, H. Y. (2014). Öğretmen niteliklerinin TIMSS 2011 fen başarısına çok düzeyli etkileri. Eğitim ve Bilim Dergisi, 39(172), 121-137. http://egitimvebilim.ted.org.tr/index.php/EB/article/view/2894/620 adresinden erişilmiştir.

Atar, H. Y., ve Atar, B. (2012). Türk eğitim reformunun öğrencilerin TIMSS 2007 fen başarılarına etkisinin incelenmesi. Kuram ve Uygulamada Eğitim Bilimleri, 12(4), 2621-2636.

Aydın, M. (2015). Öğrenci ve okul kaynaklı faktörlerin TIMSS matematik başarısına etkisi (Doktora tezi). Necmettin Erbakan Üniversitesi, Eğitim Bilimleri Enstitüsü, Konya.

Ayvaz, A. (2010). 4. sinıf matematik dersi bölme işlemi alt öğrenme alanının edebi ürünlerle işlenmesinin ögrenci başarı ve tutumuna etkisi (Yüksek lisans tezi). Sakarya Üniversitesi, Sosyal Bilimler Enstitüsü, Sakarya.

Bénabou, R., Kramarz, F., \& Prost, C. (2009). The French zones d'éducation prioritaire: Much ado about nothing? Economics of Education Review, 28(3), 345-356.

Bilican-Demir, S. (2014). Değerlendirme. S. Tekindal (Ed.), Eğitimde ölçme ve değerlendirme içinde (ss. 225257). Ankara: Pegem Akademi.

Blömeke, S., Olsen, R. V., \& Suhl, U. (2016). Teacher quality, insturactional quality and student outcomes, relationshps accross countries, cohorts and time. In T. Nilsen \& J. E. Gustafsson (Eds.), Relation of student achievement to the quality of their teachers and instructional quality (pp. 21-51). Switzerland: IEA Publishing.

Blömeke, S., Suhl, U., \& Kaiser, G. (2011). Teacher education effectiveness: Quality and equity of future primary teachers' mathematics and mathematics pedagogical content knowledge. Journal of Teacher Education, 62, 154-171.

Büyüköztürk, Ş., Çakan, M., Tan, Ş. ve Atar, H. Y. (2014). TIMSS 2011 Ulusal Matematik ve Fen Raporu. Ankara: İşkur Matbaacilık.

Büyüköztürk, Ş., Kılıç Çakmak, E., Akgün, Ö. E., Karadeniz, Ş., ve Demirel, F. (2011). Bilimsel araştırma yöntemleri. Ankara: Pegem Akademi.

Cattan, S., Kamhöfer, D. A., Karlsson, M., \& Nilsson, T. (2017). The short-and long-term effects of student absence: Evidence from Sweden (IZA DP No. 10995). Retrieved from http://ftp.iza.org/dp10995.pdf

Clinton, J. (2013). Physical activity. In: J. Hattie, and E. M. Anderman (Eds.), The international guide to student achievement (pp. 33-35). New York, NY: Taylor \& Francis.

Clinton, J., Rensford, A., \& Willing, E. (2007). Literature review of the relationship between physical activity, nutrition and academic achievement. New Zeland: Auckland Centre for Health Services, Research and Policy, University of Auckland.

Creemers, B. P., \& Kyriakides, L. (2006). Critical analysis of the current approaches to modelling educational effectiveness: The importance of establishing a dynamic model. School Effectiveness and School Improvement, 17(3), 347-366.

Çavdar, D. (2015). TIMSS 2011 matematik başarısının öğrenci ve öğretmen özellikleri ile ilişkisi (Yüksek lisans tezi). Gazi Üniversitesi, Eğitim Bilimleri Enstitüsü, Ankara.

Çelebi, N., Güner, H., Taşçı-Kaya, G. ve Korumaz, M. (2014). Neoliberal eğitim politikaları ve eğitimde firsat eşitliği bağlamında uluslararası sınavların (PISA, TIMSS ve PIRLS) analizi. Tarih Kültür ve Sanat Araştırmaları Dergisi, 3(3), 33-75. doi: 10.7596/taksad.v3i3.329 
Çokluk, Ö., Şekercioğlu, G., ve Büyüköztürk, Ş. (2018). Sosyal bilimler için çok değişkenli istatistik SPSS ve LISREL uygulamaları. Ankara: Pegem Akademi.

Daniels, D. H., \& Perry, K. E. (2003). "Learner-centered" according to children. Theory into Practice, 42(2), 102-109. doi: 10.1207/s15430421tip4202_3

Deci, E., \& Ryan, R. (1985). Intrinsic motivation and self-determination in human behavior. New York: Plenum.

Doğan, U. (2014). Validity and reliability of student engagement scale. Bartın Üniversitesi Ĕ̌gitim Fakültesi Dergisi, 3(2), 390-403. Retrieved from https://dergipark.org.tr/en/download/article-file/43660

Dwyer, T., Sallis, J. F., Blizzard, L., Lazarus, R., \& Dean, K. (2001). Relation of academic performance to physical activity and fitness in children. Pediatric Exercise Science, 13, 225-237.

Ekinci-Vural, D. (2012). Okul öncesi eğitimin ilköğretime etkisinin aile katılımı ve çeşitli değişkenler açısından incelenmesi (Doktora tezi). Dokuz Eylül Üniversitesi Eğitim Bilimleri Enstitüsü, İzmir.

Erşan, Ö. (2016). TIMSS 2011 8. Sinıf öğrencilerinin matematik başarılarını etkileyen faktörlerin yapısal eşitlik modeliyle incelemesi (Yüksek lisans tezi). Hacettepe Üniversitesi, Ankara.

Ferguson, C. J. (2009). An effect size primer: A guide for clinicians and researchers. Professional Psychology: Research and Practice, 40(5), 532-538. doi: 10.1037/a0015808

Fraenkel, J. R., Wallen, N. E., \& Hyun, H. H. (2012). How to design and evaluate research in education. New York: McGraw- Hill.

Fullarton, S., Lokan, J., Lamb, S. \& Ainley, J. (2003). Lessons from the third international mathematics and science study (TIMSS Australia Monograph No. 4). Melbourne: Australian Council for Educational Research.

Garcia, E., \& Weiss, E. (2018). Student absenteeism-Who misses school and how missingschool matters for performance (Economic Policy Institute Report). Retrieved from https://files.eric.ed.gov/fulltext/ED593361.pdf

Garson, D. (2008). Data imputation for missing values. Retrieved from https://faculty.chass.ncsu.edu/garson/PA765/index.htm

Glass, G. V., McGaw, B., \& Smith, M. L. (1981). Meta-analysis in social research. London: Sage.

Güngör, H. (2014). İlkokul 4. sınıf matematik dersi "kesirler" konusunun öğretiminde yardımcı kitap kullanımının ögrenci başarısı üzerindeki etkisi. (Yüksek lisans tezi). Yüzüncü Yıl Üniversitesi, Eğitim Bilimleri Enstitüsü, Van.

Hattie, J. (2009). Visible learning: A synthesis of over 800 meta-analyses relating to achievement. Newyork: Routledge.

Heck, R. H., \& Thomas, S. L. (2009). An introduction to multlievel modeling techniques. New York: Routledge.

Hiebert, J., Carpenter, C. P., Fennema, E., Fuson, K., Wearne, D., Murray, H., Olivier, A., \& Human, P. (1997). Making sense: Teaching and learning mathematics with understanding. Portsmouth, NH: Heinemann.

Hooper, M., Mullis, I. V. S., \& Martin, O. M. (2013). TIMSS 2015 Context questionnaire framework. In I. V. S. Mullis, \& M. O. Martin (Eds.), TIMSS 2015 assessment frameworks (pp. 61-80). United States Boston College: TIMSS and PIRLS International Study Center.

Hox, J. J. (1995). Applied multilevel analysis. Amsterdam, Netherlands: TT- publicities.

Hox, J. J. (2002). Applied multilevel analysis. Mahwah, NJ: Erlbaum.

Hox, J. J. (2010). Multilevel analysis: Techniques and applications. New York: Taylor \& Francis.

İsmail, N. A., \& Awang, H. (2008). Assessing the effects of students' characteristics and attitudes on mathematics performance. Problems of Education in $21^{\text {st }}$ Century, 9, 34-41. Retrieved from https://www.researchgate.net/profile/Noor-Ismail-

18/publication/268226049_Effects_of_Teachers_and_Schools_on_Mathematics_AchievementsProble ms_of_Education_in_the_21st_Century_Recent_Issues_in_Education/links/5466d1b10cf2397f7829e6 37/Effects-of-Teachers-and-Schools-on-Mathematics-AchievementsProblems-of-Education-in-the-

21st-Century-Recent-Issues-in-Education.pdf

İpekçioğlu-Önal, S. (2015). TIMSS 2011 cross country comparisons: relationship between student- and teacher -level factors and $8^{\text {th }}$ grade students' achievement and attitude toward science (Doctoral thesis). Middle East Technical University, Secondary Science and Mathematics Education Department, Ankara.

Karip, E. (2017). Türkiye’nin TIMSS 2015 performanst üzerine değerlendirme ve öneriler. https://tedmem.org/download/turkiyenin-timss-2015-performansi-uzerine-degerlendirme oneriler? $w p d m d l=2515$ adresinden erişilmiştir.

Kaya, S. (2008). The effects of student-level and classroom-level factors on elementary students' science achievement in five countries (Doctoral dissertation). Florida State University, Florida.

Keeley, T. J. H., \& Fox, K. R. (2009). The impact of physical activity and fitness on academic achievement and cognitive performance in children. International Review of Sport and Exercise Psychology, 2(2), 198214. doi: $10.1080 / 17509840903233822$ 
Khalid, N. (2017). Effects of absenteeism on students' performance. International Journal of Scientific and Research Publications,7(9), 151-168. Retrieved from http://www.ijsrp.org/research-paper0917.php?rp=P696781

Kılıç-Özün, S. (2010). Hayat bilgisi ögretiminde kavram karikatürü yaklaşımının öğrenci başarısı ve tutumuna etkisi (Yüksek lisans tezi). Zonguldak Karaelmas Üniversitesi, Sosyal Bilimler Enstitüsü, Zonguldak.

Klem, A. M., \& Connell, J. P. (2004). Relationships matter: Linking teacher support to student engagement and achievement. Journal of School Health, 74(7), 262-273. Retrieved from https://scholar.google.com.tr/scholar?q=Klem,+A.+M.,+\%26+Connell,+J.+P.+(2004).+Relationships+ matter:\&hl=tr\&as_sdt=0\&as_vis $=1 \& o i=$ scholart

Kolasa, K. M., Díaz, S. R., \& Duffrin, M. W. (2018). Exploring the associations among nutrition, science, and mathematics knowledge for an integrative, food-based curriculum. Journal of School Health, 88(1), 1522. doi: 10.1111 josh. 12576

Korkmaz, F. (2012). Contribution of some factors to eight grades students' science achievement in Turkey: TIMSS 2007 (Doctoral dissertation). Middle East Technical University, Ankara.

Kunuk, M. (2015). Okul öncesi ĕgitimin ilkokul ögrrencilerinin akademik başarllarına etkisi (Üsküdar örneği) (Yüksek lisans Tezi). İstanbul Aydın Üniversitesi, Sosyal Bilimler Enstitüsü, İstanbul.

Kyriakides, L. (2006). Using international comparative studies to develop the theoretical framework of educational effectiveness research: A secondary analysis of TIMSS 1999 data. Educational Research and Evaluation, 12(6), 513-534.

Lamb, S., \& Fullarton, S. (2002). Classroom and school factors affecting mathematics achievement: A comparative study of Australia and the United States using TIMSS. Australian Journal of Education, 46(2), 154-171. doi: 10.1177/000494410204600205

LaRoche, S., \& Foy, P. (2016). Sample implementation in TIMSS 2015. In M. O. Martin, I. V. S. Mullis, \& M. Hooper (Eds.), Methods and procedures in TIMSS 2015 (pp. 5.1- 5.170). Retrieved from https://timssandpirls.bc.edu/publications/timss/2015-methods/chapter-5.html

Lee, J. W., \& Barro, R. J. (2001). Schooling quality in a cross-section of countries. Economica, New Series, 68(272), 465-488.

Lee, V. E., \& Zuze, T. L. (2011). School resources and academic performance in Sub-Sharan Africa. Comparative Education Review, 55(3), 369-397. Retrieved from https://www.jstor.org/stable/10.1086/660157?seq=1

Lieberman, D. A., Bates, C. H., \& So, J. (2009) Young children's learning with digital media. Computers in the Schools, 26(4), 271-283. doi: 10.1080/07380560903360194

Liouaeddine, M., Bijou, M., \& Naji, F. (2017). The main determinants of Moroccan students' outcomes. American Journal of Educational Research,5(4), 367-383. doi: 10.12691/education-5-4-5

Martin, M. O., Mullis, I. V. S., \& Foy, P. (2013). TIMSS 2015 assessment design. In I. V. S. Mullis \& M. O. Martin (Eds.), TIMSS 2015 assessment frameworks (pp. 85-96). Chestnut Hill, MA: TIMSS \& PIRLS International Study Center, Boston College.

Martin, M. O., Mullis, I. V. S., Foy, P., \& Hooper, M. (2016). TIMSS 2015 international results in science. Retrieved from http://timssandpirls.bc.edu/timss2015/international-results/

Martin, M. O., Mullis, I. V. S., Gonzalez, E. J., Gregory, K. D., Smith, T. A., Chrostowski, S. J., Garden, R. A. \& O'Connor, K. M. (2000). TIMSS 1999 international science report. Retrieved from https://timssandpirls.bc.edu/timss1999i/pdf/T99i_Sci_All.pdf

Martin, M. O., Mullis, İ. V. S., Hooper, M, Yin, L., Foy, P., \& Palazzo, L. (2016). Creating and interpreting the TIMSS 2015 context questionnaire scales. In M. O. Martin, I. V. S. Mullis \& M. Hooper (Eds.), Methods and procedures in TIMSS 2015 (pp. 15.1-15.312). Retrieved from https://timss.bc.edu/publications/timss/2015-methods/chapter-15.html

Marzano, R. J. (2003). What works in school: Translating research into action (1st ed.). Alexandria, VA: Association for Supervision \& Curriculum Development.

Mertler, C. A., \& Vannatta, R. A. (2005). Advanced and multivariate statistical methods: Practical application and interpretation (3rd ed.). Glendale, CA: Pyrcz Publishing.

Mohammadpour, E., \& Abdul Ghafar, M. N. (2014). Mathematics achievement as a function of within-andbetween school differences. Scandinavian Journal of Educational Research, 58(2), 189-221. doi: 10.1080/00313831.2012.725097

Mohammadpour, E., Shekarchizadeh, A., \& Kalantarrashidi, S. A. (2015). Multilevel modeling of science achievement in the TIMSS participating countries. The Journal of Educational Research, 108(6)1-16. doi: 10.1080/00220671.2014.917254

Mullis, I. V. S., Martin, M. O., Gonzalez, E. J., \& Kennedy, A. M. (2003). PIRLS 2001 international report: IEA's study of reading literacy achievement in primary school in 35 countries. Chestnut Hill, M.A.: International Study Center, Boston College. 
Nilsen, T., Gustafsson, J. E. \& Blömöke, S. (2016). Conceptual framework and methodology of the report. In T. Nilsen \& J. E. Gustafsson (Eds.), Teacher quality, insturactional quality and student outcomes, relationshps accross countries, cohorts and time (pp. 1-21). Switzerland: IEA Publishing. Retrieved from https://link.springer.com/chapter/10.1007/978-3-319-41252-8_1

Organisation for Economic Co-operation and Development. (2013). Education Policy Outlook: Turkey. Retrieved from http://www.oecd.org/edu/EDUCATION\%20POLICY\%20OUTLOOK\%20TURKEY_EN.pdf.

Organisation for Economic Co-operation and Development. (2015). Education at a Glance. Retrieved from https://www.oecd-ilibrary.org/education/education-at-a-glance-2015_eag-2015-en

Olson, J. F., Martin, M. O. \& Mullis, I. V. S. (2008). TIMSS 2007 technical report. United States: International Study Center, Boston College.

Ozborne, J. W. (2002). Notes on the use of data transformations. Practical Assessment Research anad Evaluation, 8.

Özdemir, S. (2013). Türk eğitim sistemi ve okul yönetimi. S. Özdemir (Ed.), Türk ĕgitim sisteminin yapısl, eğilimleri ve sorunları içinde (ss. 7- 52). Ankara: Pegem Akademi.

Özden, M. (2007). Problems with science and technology education in Turkey. Eurasia Journal of Mathematics, Science \& Technology Education, 3(2), 157-161. Retrieved from https://www.ejmste.com/download/problems-with-science-andtechnology-education-in-turkey4061.pdf

Özgen, C. (2009). The connection between school and student characteristics with mathematics achievement in Turkey (Doctoral dissertation). Middle East Technical University, Varsa Enstitü Bilgisi, Ankara.

Raudenbush, S. V., \& Bryk, A. S. (2002). Hierarchical linear models: Applications and data analysis methods. London: Sage.

Reddy, V. (2005). Cross-national achievement studies: learning from South Africa's participation in the trends in international mathematics and science study (TIMSS). A Journal of Comparative and International Education, 35(1), 63-77. doi: 10.1080/03057920500033571

Ryan, R. M., \& Deci, E. L. (2000). Self-determination theory and the facilitation of intrinsic motivation, social development, and well-being. American Psychologist, 55(1), 68-78. Retrieved from https://selfdeterminationtheory.org/SDT/documents/2000_RyanDeci_SDT.pdf

Ryoo, H. (2001). Multilevel influences on student achievement: An international comparative study (Doctoral dissertation). Available from ProQuest Dissertations and Theses database.

Sarı, M. H., Arıkan, S. ve Yıldızlı, H. (2017). 8. Sınıf matematik akademik başarısını yordayan faktörler-TIMSS 2015. Eğitimde ve Psikolojide Ölçme ve Değerlendirme Dergisi, 8(3), 246-265. doi: 10.21031/epod.303689

Savaş, E., Taş, S. ve Duru, A. (2016). Factors affecting students' achievement in mathematics. Inonu University Journal of the Faculty of Education, 11(1), 113-132. Retrieved from https://dergipark.org.tr/tr/download/article-file/92276

Selçuk, E. (2015). Müzik dersinde zihin haritalama tekniği kullanımının ögrenci başarısı ve tutumlarına etkisi (Yüksek lisans tezi). Marmara Üniversitesi Eğitim Bilimleri Enstitüsü, İstanbul. https://tez.yok.gov.tr/UlusalTezMerkezi/tezDetay.jsp?id=oBF44VZN7pDvnhafMH48dw\&no=151CbO tziZRIPV_Nj4M4RQ adresinden erişilmiştir.

Sevgi, S. (2009). The connection between school and student characteristics with mathematics achievement in Turkey (A thesis submitted to the graduate). Middle East Technical Universty, Secondary Science and Mathematics Education Department, Ankara.

Sezer, E. (2016). Öğretmenlerin kişisel ve mesleki niteliklerinin 4 ve 8. Sinıf ögrencilerinin TIMSS 2011 matematik başarısına etkisinin incelenmesi (Yüksek lisans tezi). Gazi Üniversitesi, Eğitim Bilimleri Enstitüsü, Ankara.

Shaw, S. R., Gomes, P., Polotskaia, A., \& Jankowska, A. M. (2015). The relationship between student health and academic performance: Implications for school psychologists. School Psychology International, 36(2), 115-134. doi: 10.1177/0143034314565425

Sirin, S. R. (2005). Socioeconomic status and academic achievement: A meta- analytic review of research. Review of Educatilnal Research, 75(3), 417-453. doi: 10.3102/00346543075003417

Stemler, S. E. (2001). Examining school effectiveness at the fourth grade: A hierarchical analysis of the third international mathematics and science study (TIMSS). (Submitted in partial fulfillment of the requirements for the degree of Doctor of Philosophy). Wesleyan University, Department of Psychology, United States.

Tabachnick, B. G., \& Fidell, L. S. (2001). Using multivariate statistics. Boston: Ally and Bacon.

Taştekinoğlu, E. (2014). 4. sınıf matematik sorularının bilişsel alan kapsamında incelenmesi; TIMSS sınav sorularıyla karşılaştırmalı bir analiz (Yüksek lisans tezi). İstanbul Aydın Üniversitesi, Sosyal Bilimler Enstitüsü, İstanbul. 
Toraman, Ç., Akay, E., Özdemir, H. F. ve Karadağ, E. (2011). Çok düzeyli regresyon modelleri, HLM uygulamalart. Ankara: Nobel.

Trautwein, U. (2007). The homework achievement relation reconsidered: Differentiating homework time, homework frequency, and homework effort. Learning and Instruction, 17(3), 372-388. doi: 10.1016/j.learninstruc.2007.02.009

Uzun, S., Bütüner, S. Ö. ve Yiğit, N. (2010). A comparison of the results of TIMSS 1999-2007: The most successful five countries-Turkey sample. Elementary Education Online, 9(3), 1174-1188. Retrieved from https://dergipark.org.tr/tr/download/article-file/90742

Van de Valle, J. A., Karp, K. S., \& Bay-Williams, J. M. (2010). Elementary and middle school mathematics teaching developmentally. USA, Pearson.

van den Broeck, A., Opdenakker, M. C., \& Van Damme, J. (2005). The effects of student characteristics on mathematics achievement in Flemish TIMSS 1999 data. Educational Research and Evaluation, 11(2), 107-121. doi: 10.1080/13803610500110745

Webster, B. J., \& Fisher, D. L. (2000). Accounting for variation in science and mathematics achievement: A multilevel alaysis of Australian data third international mathematics and science study. School Effectivenes and School Improvement, 11(3), 339-360.

Wenglinsky, H. (2000). How teaching matters: Bringing the classroom back into discussions of teacher quality. Princeton, NJ: Educational Testing Service.

Won, S. J., \& Han, S. (2010). Out-of-school activities and achievement among middle school students in the U.S. and South Korea. Journal of Advanced Academics, 21(4), 628-661. doi: $10.1177 / 1932202 X 1002100404$

World Bank (2011). Improving the quality and equity of basic education in turkey challenges and options. The World Bank: Washington D.C.

Wößmann, L. (2003). Schooling resources, educational institutions and pupil performance: international evidence. Oxford Bull Economics Statistics, 65(2), 117-170. doi: 10.1111/1468-0084.00045

Yaman, İ. (2004). Modeling the realationship between the science teacher characteristics and eight grade Turkish student science achievement in TIMSS- R (Yüksek lisans tezi). Orta Doğu Teknik Üniversitesi, Fen Bilimleri Enstitüsü, Ankara.

Yatağan, M. (2014). Fen ve teknoloji dersi öğretim programının öğrenci ve ögrretmen özelliklerine göre değerlendirilmesi: TIMSS 2007 ve 2011 verileri ile bir durum analizi (Doktora tezi). Gazi Üniversitesi, Eğitim Bilimleri Enstitüsü, Ankara.

Yılmaz, H. B., ve Aztekin, S. (2012, Haziran). Türkiye 'deki düzey istatistiki bölge birimlerine göre 15 yaş grubu ögrencilerinin akademik başarılarını etkileyen bazı faktörlerin incelenmesi. X. Ulusal Fen Bilimleri ve Matematik Eğitimi Kongresinde sunulan sözlü bildiri, Niğde, Türkiye.

Yücel, C., ve Karadağ, E. (2016). TIMSS 2015 Türkiye; Patinajdaki ĕgitim. doi: 10.13140/RG.2.2.20445.20964/1

Zhu, Y., \& Leung, F. K. S. (2012). Homework and mathematics achievement in Hong Kong: Evidence from the TIMSS 2003. International Journal of Science and Mathematics Education, 10(4), 907-92. doi: $10.1007 / \mathrm{s} 10763-011-9302-3$ 